\title{
Concreto reforçado com fibras de polipropileno: estudo de caso para aplicação em painel alveolar de parede fina
}

Orientador: Prof. Dr. Mounir Khalil El Debs 
AUTORIZO A REPRODUÇÃO TOTAL OU PARCIAL DESTE TRABALHO, POR QUALQUER MEIO CONVENCIONAL OU ELETRÔNICO, PARA FINS DE ESTUDO E PESQUISA, DESDE QUE CITADA A FONTE.

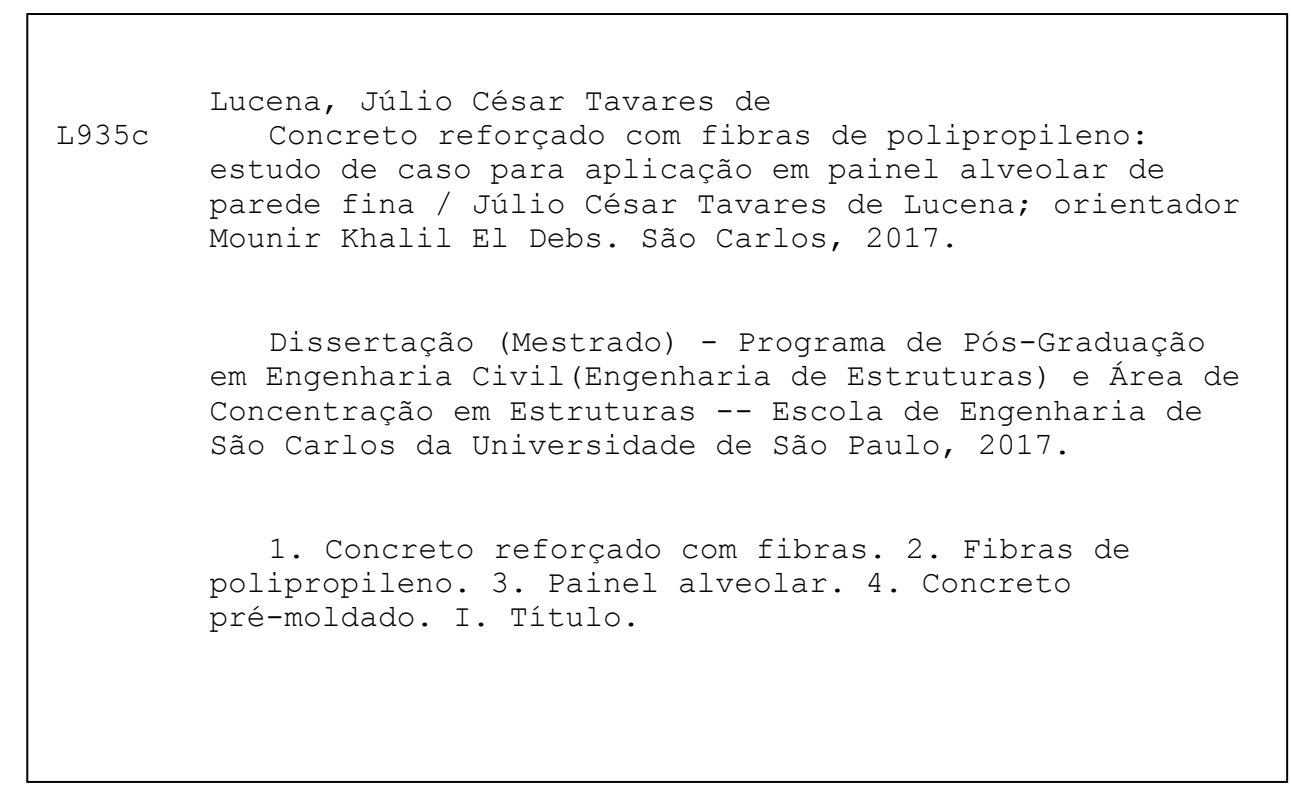




\section{FOLHA DE JULGAMENTO}

Candidato: Engenheiro JÚLIO CÉSAR TAVARES DE LUCENA

Título da dissertação: "Concreto reforçado com fibras de polipropileno:

estudo de caso para aplicação em painel alveolar de parede fina"

Data da defesa: 03.03.2017

Comissão Julgadora:

Resultado:

Prof. Titular Mounir Khalil El Debs

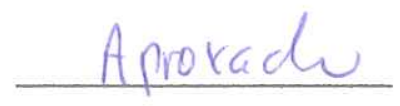

(Orientador)

(Escola de Engenharia de São Carlos/EESC)

Prof. Dr. Daniel de Lima Araújo

(Universidade Federal de Goiás/UFG)

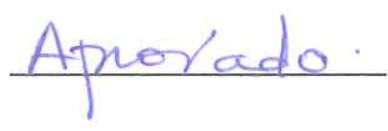

Prof. Dr. Gustavo Henrique Siqueira

(Universidade Estadual de Campinas/UNICAMP)

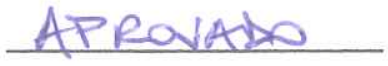

Coordenador do Programa de Pós-Graduação em Engenheira Civil (Engenharia de Estruturas):

Prof. Titular Humberto Breves Coda

Presidente da Comissão de Pós-Graduação:

Prof. Associado Luís Fernando Costa Alberto 



\section{RESUMO}

LUCENA, J. C. T. Concreto reforçado com fibras de polipropileno: estudo de caso para aplicação em painel alveolar de parede fina. 2017. 83 f. Dissertação (Mestrado em Engenharia de Estruturas) - Escola de Engenharia de São Carlos, Universidade de São Paulo, São Carlos, 2017.

Essa pesquisa apresenta um estudo da composição de concreto reforçado com fibras de polipropileno e objetiva avaliar seu comportamento estrutural em um tipo de painel alveolar de parede fina. A adição de alto teor de fibras de polipropileno ao concreto modifica algumas de suas propriedades mecânicas, conferindo ao compósito maior resistência à tração, resistência à flexão, resistência ao impacto e tenacidade. Inicialmente foram realizados ensaios de caracterização do compósito, sendo eles: consistência, resistência à compressão axial, módulo de elasticidade, resistência à tração por compressão diametral, resistência à tração na flexão e tenacidade. Estudou-se o comportamento de todas essas propriedades mecânicas para os teores de fibras de polipropileno de 0,1 e $2 \%$ em volume de concreto. Com intuito de estudar o comportamento mecânico dos painéis alveolares de parede fina pela adição de fibras, foram realizados ensaios de carga concentrada e flexão. Este estudo foi realizado para os teores de fibra de 0 e $2 \%$. Foram produzidos dois tipos de corpos de prova, ambos com seção transversal de $300 \mathrm{~mm} \times 140 \mathrm{~mm}$, e comprimentos de $600 \mathrm{~mm}$ e $1200 \mathrm{~mm}$, para cada teor de fibra e respectivamente para os ensaios de carga concentrada e flexão. Para os ensaios de caracterização, não houve indícios de resultados significantes da adição dos teores de fibras 1 e $2 \%$ para a resistência à compressão e módulo de elasticidade. Já os ensaios de consistência, resistência à tração e tenacidade, apresentaram resultados expressivos, principalmente para o teor de fibra de $2 \%$. Para os ensaios nos corpos de prova no painel quanto à carga concentrada, observou-se aproximadamente dez vezes maior capacidade de carga, cinco vezes maior capacidade de deslocamento e sete vezes maior resistência à punção. Os ensaios à flexão no painel apresentaram tensões resistentes pouco menores para os corpos de prova do painel contendo $2 \%$ de fibras. Conclui-se então que as propriedades do material cimentício com elevado teor de fibras são apropriadas para aplicação em painéis alveolares de parede fina. No entanto, é necessário melhorar a trabalhabilidade da mistura, pois devido às pequenas espessuras das paredes do painel, o adensamento do material não foi realizado de forma satisfatória.

Palavras-chave: Concreto reforçado com fibras. Fibras de polipropileno. Painel alveolar. Concreto pré-moldado. 



\begin{abstract}
LUCENA, J. C. T. Polypropylene fibers reinforced concrete: case study for thin-walled hollow core panel application. 2017. 83p. Dissertation (M. Sc. in Structural Engineering) School of Engineering of São Carlos, University of São Paulo, São Carlos, 2017.
\end{abstract}

This research presents a study on the composition of polypropylene fiber reinforced concrete and intents to evaluate its structural behavior in a type of thin-walled hollow core panel. The addition of high content of polypropylene fibers to the concrete modifies some of its mechanical properties, giving the composite greater split tensile strength, flexural strength, impact strength and toughness. Firstly, characterization tests of the composite were performed: consistency, compressive strength, modulus of elasticity, split tensile strength, flexural tensile strength and toughness. It was studied the behavior of all these mechanical properties for the contents of polypropylene fibers of 0,1 and $2 \%$ by volume of concrete. In order to study the mechanical behavior of the thin-walled hollow core panels by the addition of fibers, were performed concentrated load and flexural tests. This study was performed for fiber contents of 0 and $2 \%$. Two types of specimens were produced, both with a cross section of $300 \mathrm{~mm} \times 140 \mathrm{~mm}$, and lengths of $600 \mathrm{~mm}$ and $1200 \mathrm{~mm}$, for each fiber content and to be tested respectively for the concentrated load and flexural tests. For the characterization tests, there was no evidence of significant results arising on the addition of the fiber contents 1 and $2 \%$ for the compressive strength and modulus of elasticity. The tests of consistency, tensile strength and toughness presented significant results, especially for the fiber content of $2 \%$. The flexural tests on the panel showed slightly lower tensile strengths for specimens containing $2 \%$ fibers. It is then concluded that the properties of the high fiber cementitious material are suitable for application in thin-walled alveolar panels. However, it is necessary to improve the workability of the composite, because due to the small thicknesses of the panel walls, a satisfactorily consolidation of the material has not been achieved.

Keywords: Fiber reinforced concrete. Polypropylene Fibers. Hollow-core panel. Precast concrete. 



\section{LISTA DE FIGURAS}

Figura 1.1 - Disposições típicas dos painéis de fechamento (Castilho, 1998) 19

Figura 1.2 - Exemplo de sistema construtivo utilizando painéis pré-fabricados de concreto (FIB - Affordable Housing IX, 2010).

Figura 1.3 - Seção transversal ilustrativa do painel básico com ordem de grandeza das dimensões (E1 Debs, 2016)

Figura 1.4 - Aplicação do painel básico em paredes (E1 Debs, 2016) 21

Figura 1.5 - Seção transversal prevista para lajes e sua aplicação associada a concreto moldado no local (El Debs, 2016) 22

Figura 2.1 - Comportamento carga-deformação de concreto convencional e FRC (Hanna, A.C., 1977 apud Mehta e Monteiro, 2008) 28

Figura 2.2 - Mecanismo de aumento de tenacidade à flexão do concreto com fibra (Johnson, 1980 apud Mehta e Monteiro, 2008)

Figura 2.3 - Curva tensão-deformação do concreto para os diferentes volumes de fibras de polipropileno (Kim et al., 2010)

Figura 3.1 - Curva granulométrica da areia (Fonte: Autor) 36

Figura 3.2 - Fibra de polipropileno utilizada na pesquisa (BRASILIT - Saint Gobain Fonte: Autor)

Figura 4.1 - Argamassa com fibras no estado fresco

Figura 4.2 -Seção transversal do corpo-de-prova do painel - medidas em milímetros (Fonte: Autor)

Figura 4.3 - Geometria do corpo-de-prova para ensaios de carga concentrada (a) e resistência à flexão (b) - medidas em milímetros (Fonte: Autor)

Figura 4.4 - Corte do corpo de prova do painel de $1200 \mathrm{~mm}$ para obtenção de dois modelos de $600 \mathrm{~mm}$ de comprimento (Fonte: Autor) 
Figura 4.5 - Etapas de lançamento da argamassa. Fundo (a) e (b) e parte superior (c) e (d) da forma, antes e depois do lançamento. (Fonte: Autor).

Figura 4.6 - Misturador industrial utilizado na pesquisa (a) e detalhe da paleta misturadora (b) (Fonte: Autor). 44

Figura 4.7 - Fases do ensaio de consistência (Fonte: Autor) ..................................... 46

Figura 4.8 - Esquema do ensaio acústico (Haach et al., 2013) ................................. 47

Figura 4.9 - Ensaio acústico em corpo de prova de argamassa reforçada com fibras de polipropileno (Fonte: Autor) 48

Figura 4.10 - Esquema de ensaio para determinação da resistência à tração na flexão medidas em mm (Fonte: Autor) 50

Figura 4.11 - Prepaparação do corpo de prova para o ensaio (a), ruptura do corpo de prova e fim do ensaio (b) e comparação dos corpos de prova sem fibras e com fibras após a finalização do ensaio (c) (Fonte: Autor) 50

Figura 4.12 - Esquema de ensaio para determinação da resistência de tenacidade e detalhe no entalhe - medidas em mm (Fonte: Autor).... 52

Figura 4.13 - Detalhe do corpo de prova durante o ensaio (a) e pós ensaio (b) (Fonte: Autor) 52

Figura 4.14 - Face do plano de ruptura dos corpos de prova para os diferentes teores de fibras utilizados na pesquisa (Fonte: Autor) 53

Figura 4.15 - Localização dos pontos de aplicação da carga para o ensaio de carga concentrada (carga aplicada isoladamente em cada um dos pontos) (Fonte: Autor). 54

Figura 4.16 - Preparação do corpo de prova para o ensaio de carga concentrada (Fonte: Autor) 54

Figura 4.17 - Furo após a finalização do ensaio e cone extraído do corpo de prova da região do ensaio (Fonte: Autor) 55

Figura 4.18 - Localização dos transdutores de deslocamento em corte (a) e em planta (b) do corpo de prova do painel para o ensaio de flexão (Fonte: Autor) 56 
Figura 4.19 - Preparação do corpo de prova para o ensaio de flexão (Fonte: Autor)...56

Figura 4.20 - Detalhe dos corpos de prova com 2\% de fibras (a) e sem fibras (b) rompidos após o ensaio (Fonte: Autor)

Figura 5.1 - Resultados do ensaio de compressão axial (Fonte: Autor)

Figura 5.2 - Resultados do ensaio de módulo de elasticidade

Figura 5.3 - Resultados do ensaio de tração por compressão diametral (Fonte: Autor)

Figura 5.4 - Resultados do ensaio de tração na flexão (Fonte: Autor) 63

Figura 5.5- Curvas Força-Deslocamento vertical de ensaio de tenacidade para teor de fibra $0 \%$ (Fonte: Autor). 64

Figura 5.6 - Curvas Força-deslocamento vertical de ensaio de tenacidade para teor de fibra $1 \%$ (Fonte: Autor).

Figura 5.7 - Curvas Força-deslocamento vertical de ensaio de tenacidade para teor de fibra 2\% (Fonte: Autor).

Figura 5.8 - Curvas médias de Força - deslocamento vertical para os teores de fibra 0, 1 e $2 \%$ (Fonte: Autor) 66

Figura 5.9 - Gráfico da curva média da Força-Deslocamento do ponto do ensaio de carga concentrada para a teor de fibra de $2 \%$ e traço de referência (espessura da parede de 12 $\mathrm{mm}$ ) (Fonte: Autor) 67

Figura 5.10 - Gráfico Força-Deslocamento do ensaio de flexão das amostras sem fibras (Fonte: Autor) 68

Figura 5.11 - Gráfico Força-Deslocamento do ensaio de flexão das amostras com $2 \%$ de fibras de polipropileno (Fonte: Autor). 69

Figura 5.12 - Configuração do carregamento do ensaio e diagrama de momento fletor subsequente (Fonte: Autor) 



\section{LISTA DE TABELAS}

Tabela 2.1 - Propriedades típicas das fibras sintéticas (Bentur e Mindess, 2007)........31

Tabela 2.2 - Resultado dos ensaios de resistência (Song, Hwang e Sheu, 2004).........33

Tabela 2.3 - Propriedades do concreto leve reforçado com fibras de polipropileno (Kim et al., 2010)

Tabela 3.1 - Características do cimento Portland utilizado (HOLCIM S.A.)................35

Tabela 3.2 - Massa específica e massa unitária da areia utilizada na pesquisa .............36

Tabela 3.3 - Propriedades das fibras de polipropileno (BRASILIT-Saint Gobain) ......37

Tabela 3.4 - Propriedades do super plastificante (BASF - GLENIUM 51) .................38

Tabela 4.1 - Traço em massa de argamassa reforçada com fibras de polipropileno ((Fonte: Autor)) .40

Tabela 4.2 - Traço em massa da argamassa de referência ..........................................4 41

Tabela 5.1 - Resultados dos ensaios de consistência (Fonte: Autor)............................59

Tabela 5.2 - Resultados dos ensaios de compressão axial (Fonte: Autor)....................60

Tabela 5.3 - Resultados dos ensaios de módulo de elasticidade.................................61

Tabela 5.4 - Resultados dos ensaios de tração por compressão diametral (Fonte: Autor)

Tabela 5.5 - Resultados dos ensaios de tração na flexão (Fonte: Autor) 63

Tabela 5.6 - Resultados dos ensaios de tenacidade (Fonte: Autor) 64

Tabela 5.7 - Resumo dos resultados do ensaio de carga concentrada (Fonte: Autor) .. 67

Tabela 5.8 - Resultados do ensaio de flexão para amostras sem fibras (Fonte: Autor) 71

Tabela 5.9 - Resultados do ensaio de flexão para amostras com $2 \%$ de fibras de polipropileno (Fonte: Autor) 
Tabela A.1 - Traço em massa das argamassas do estudo preliminar (Fonte: Autor).. 79

Tabela A.2 - Resultados dos ensaios de resistência à compressão - relação a/c 0,35 (Fonte: Autor) 79

Tabela A.3 - Resultados dos ensaios de resistência à compressão - relação a/c 0,4 (Fonte: Autor) 80

Tabela A.4 - Resultados dos ensaios de resistência à compressão - relação a/c 0,45 (Fonte: Autor) 80

Tabela A.5 - Resultados do ensaio de compressão axial (Fonte: Autor) 81

Tabela A.6 - Resultados do ensaio de tração por compressão diametral (Fonte: Autor) 82

Tabela A.7 - Resultados do ensaio de módulo de elasticidade (Fonte: Autor) 82

Tabela A.8 - Resultados do ensaio de consistência (Fonte: Autor) 83

Tabela A.9 - Resultados do ensaio de tração na flexão (Fonte: Autor) 83 


\section{SUMÁRIO}

1 INTRODUÇÃO .............................................................................................17

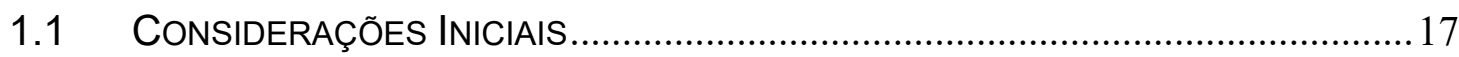

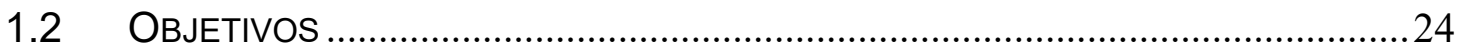

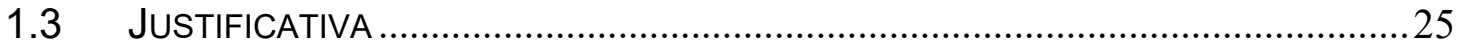

2 REVISÃO BIBLIOGRÁFICA ...............................................................................27

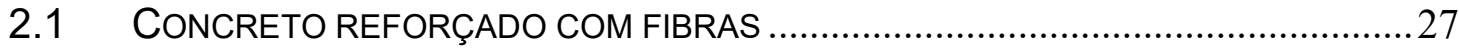

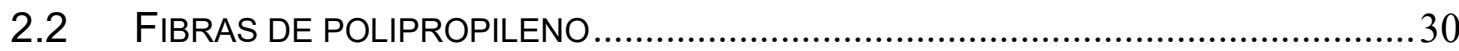

2.3 CONCRETO REFORÇADO COM FIBRAS DE POLIPROPILENO ...............................31

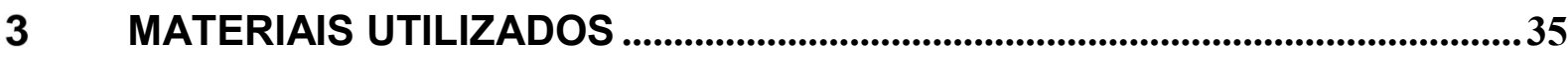

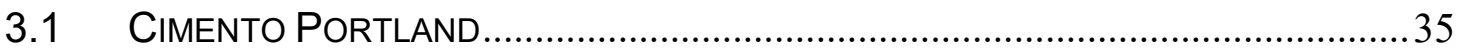

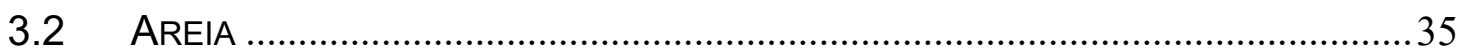

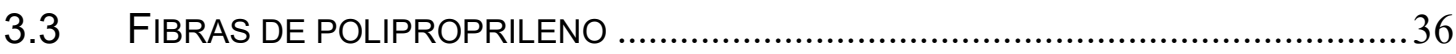

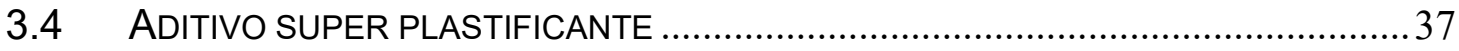

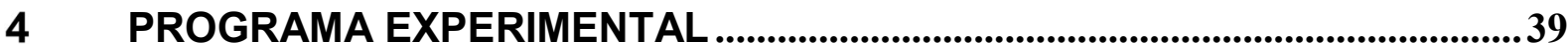

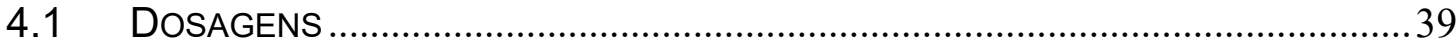

4.2 PRODUÇÃO DOS CORPOS DE PROVA DE PAINÉIS ALVEOLARES..........................41

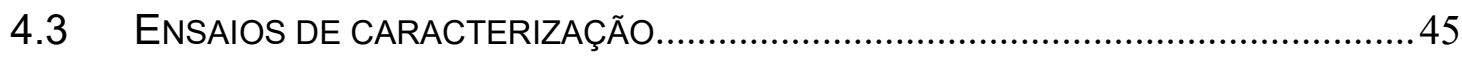

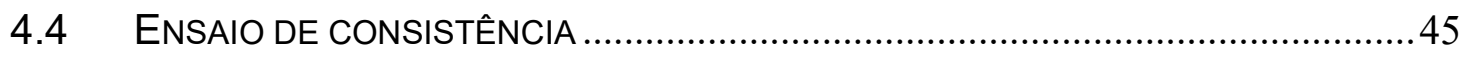

4.4.1 Ensaio de compressão axial .........................................................46

4.4.2 Ensaio de módulo de elasticidade ...................................................46

4.4.3 Ensaio de tração por compressão diametral......................................47

4.4.4 Ensaio de tração na flexão ...............................................................49

4.4.5 Ensaio de tenacidade à fratura............................................................51

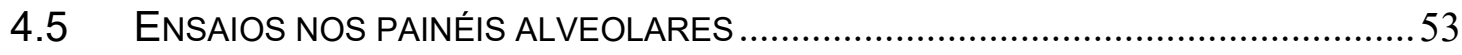

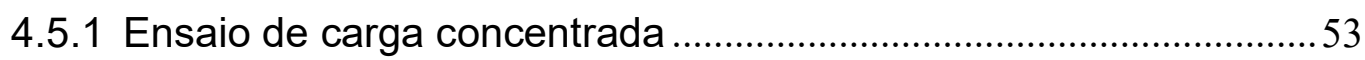

4.5.2 Ensaio de resistência à flexão ...............................................................55

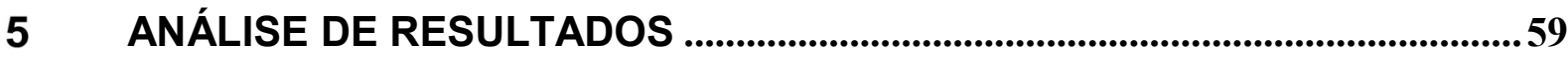

5.1 ENSAIO DE CARACTERIZAÇÃO DAS PROPRIEDADES DA ARGAMASSA MODIFICADA 


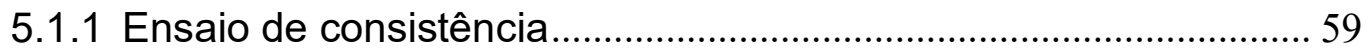

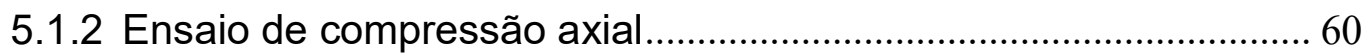

5.1.3 Ensaio de módulo de elasticidade .................................................. 61

5.1.4 Ensaio de tração por compressão diametral .................................. 62

5.1.5 Ensaio de tração na flexão ............................................................. 63

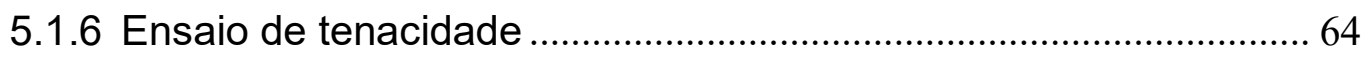

5.2 ENSAIO NOS CORPOS DE PROVA DO PAINEL ALVEOLAR .................................66

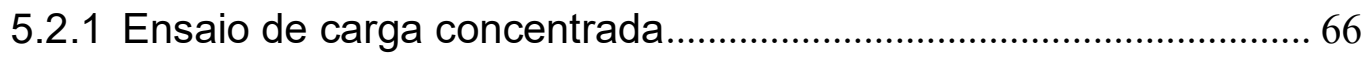

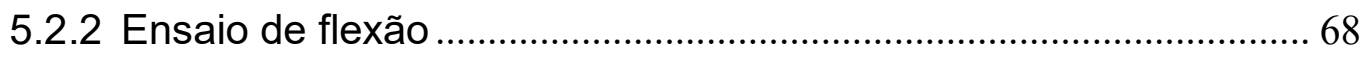

6 CONCLUSÃO E CONSIDERAÇÕES FINAIS ................................................ 73

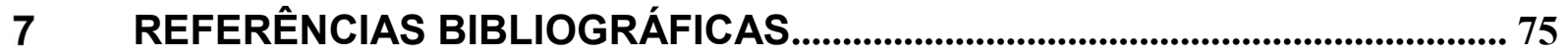

ANEXO A - RESULTADO DOS ENSAIOS EXPERIMENTAIS .................................... 79 


\section{INTRODUÇÃO}

\subsection{Considerações Iniciais}

A definição mais evidente para concreto pré-moldado é um concreto que é moldado e curado em um local que não é o seu destino final (Elliott, 2002).

Edificações com elementos de concreto pré-moldado são tão antigas quanto às com concreto moldado no local. Apenas na segunda metade do século passado, no entanto, esta forma de processo construtivo tomou sua forma industrializada. Os fatores que contribuíram para isso foram, em particular, o desenvolvimento de equipamentos pesados de elevação, a utilização de formas de aço mecanizadas e, mais recentemente, sistemas de produção automatizados (Bachmann e Steinle, 2011).

Dentre os motivos para a utilização de elementos de concreto pré-moldado, citam-se abaixo algumas características que favorecem seu emprego quanto à qualidade, custos de produção e tempo de construção.

\section{a) Qualidade:}

- A produção em um ambiente interno resulta em melhores condições de trabalho com correspondentemente melhor produtividade em comparação ao que seria produzido em um canteiro de obras;

- Na situação de produção em fábrica, a mão-de-obra é qualificada, diferentemente da situação em campo, onde, em geral, há escassez de trabalhadores qualificados;

- Formas de aço podem ser utilizadas para elementos de pequeno ou de grande porte, o que permite atingir um elevado grau de precisão dimensional;

- A produção em fábrica permite o alcanço de uma qualidade específica de concreto;

- Somente através da produção em fábrica é possível a produção de elementos de concreto com texturas e cores arquitetônicas, especialmente para projetos de fachada;

- Assim como acontece em outros ramos industriais fora do setor da construção civil, a produção em fábrica resulta em uma gestão mais eficiente do trabalho e da qualidade.

\section{b) Custos de produção:}


- Umas das principais finalidades de se construir com concreto pré-moldado é reduzir o custo das formas. Vários elementos podem ser produzidos utilizando-se a mesma forma, o que em grandes lotes é naturalmente mais vantajoso;

- Outro motivo para se construir com concreto pré-moldado é, sem dúvida, a redução ou total eliminação dos custos de andaimes;

- A fábrica de produção permite o uso de mecanização e automação, o que por sua vez pode resultar em uma redução substancial no número de horas de funcionamento necessárias. No entanto, se a capacidade de uma fábrica não é totalmente explorada, torna-se uma desvantagem devido à alta proporção de custos fixos;

- Redução da quantidade de materiais a partir da possibilidade da utilização de seções transversais mais finas, atendendo-se aos requisitos estruturais para os quais os elementos são projetados. Logo, os elementos também apresentam redução de peso próprio. Um exemplo típico de redução de material e peso são as diferenças presentes entre uma laje maciça e uma alveolar;

- Maior facilidade de protensão dos elementos, principalmente no caso de prétração;

- Um importante fator de custo para uma fábrica de pré-moldados é o de transporte, o que limita o raio de atividades e mercado.

\section{c) Velocidade de construção:}

- Uma grande vantagem da construção com concreto pré-moldado é a redução do tempo de construção. Por exemplo, elementos de pavimentos e de vedação (paredes/painéis) podem ser fabricados simultaneamente, mesmo quando a fundação ainda está sendo construída;

- A economia associada a um tempo de produção mais curto e, consequentemente, as chances de gerar receitas em uma data anterior são importantes, tornando-se uma das principais razões para construção de concreto pré-moldado em edificações industriais;

- No entanto, não deve ser esquecido que as estruturas feitas com elementos de concreto pré-moldado geralmente exigem um maior planejamento e informações ao se projetar. Por outro lado, essas informações podem ser substancialmente reduzidas utilizando um sistema de elementos pré-moldados normalizados. 
Uma das aplicações do concreto pré-moldado é seu emprego em painéis de fechamento tanto para estruturas principais em concreto pré-moldado, como em combinação com estruturas de concreto moldado no local e com estruturas de aço.

Quanto à disposição dos painéis, eles se apresentam usualmente de três diferentes maneiras. Podem ser dispostos cobrindo o vão entre pilares ao longo da estrutura (Figura 1.1. a); com diversos painéis cobrindo o vão para estruturas de vários pavimentos (Figura 1.1. b); ou com diversos painéis cobrindo o vão para estruturas de um pavimento (Figura 1.1. c).

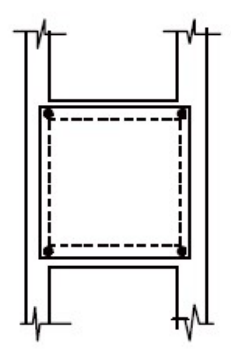

a)

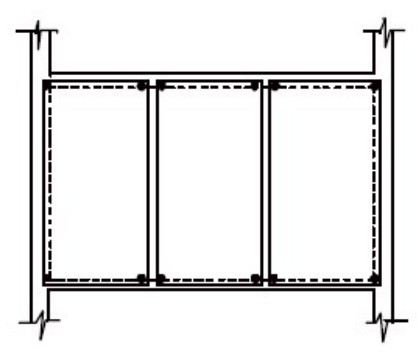

b)

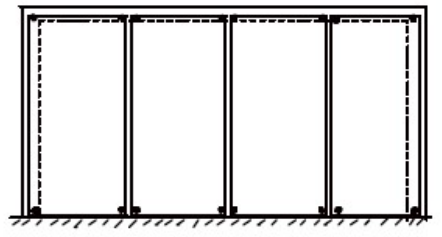

c)

Figura 1.1 - Disposições típicas dos painéis de fechamento (Castilho, 1998)

Recentemente, muita atenção tem sido dada para a aplicação de concreto leve em elementos pré-moldados a fim de melhorar o seu desempenho, como a redução de carga permanente, resistência ao fogo e condutividade térmica das edificações (Hassanpour, Shafigh e Mahmud, 2012).

O FIB - Affordable Housing IX (2010) apresenta considerações sobre construções sustentáveis de habitações em pré-fabricados quanto à:

- Materiais;

- Sistemas estruturais;

- Produção, transporte e montagem;

- Impermeabilização e isolamento térmico;

- Instalações.

Ao final do documento são apresentados diversos sistemas construtivos que são utilizados em partes do mundo. Entre os sistemas construtivos, faz-se a divisão entre sistemas de pórticos, parede (painéis) e mistos. A Figura 1.2 mostra um exemplo de sistema construtivo utilizando painéis de concreto apresentados na obra. 

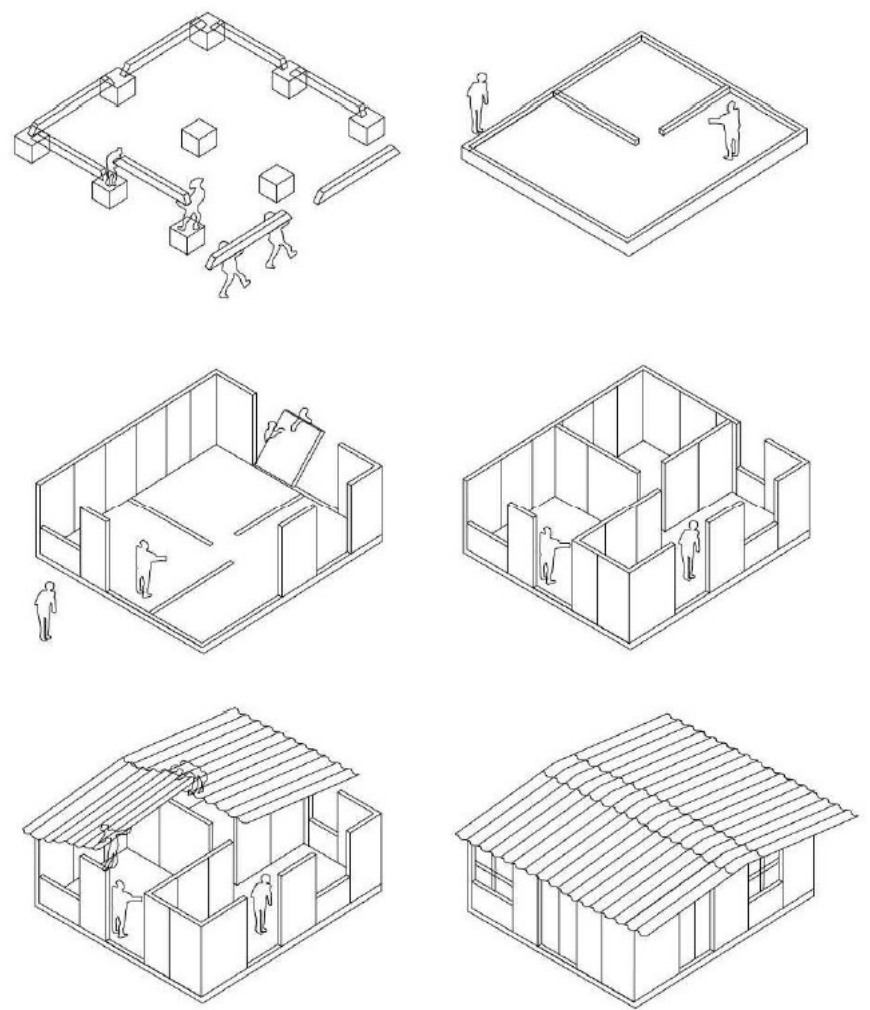

Figura 1.2 - Exemplo de sistema construtivo utilizando painéis pré-fabricados de concreto (FIB - Affordable Housing IX, 2010)

El Debs (2016) idealizou um sistema construtivo no qual são empregados componentes pré-fabricados, que seriam montados na obra e ligados com grautes e/ou concreto moldado no local para formar as estrutura e fechamento da construção, de forma integrada com as instalações. Os componentes pré-fabricados teriam produção em fábrica a partir de painéis alveolares de material cimentício de pequenas espessuras de paredes, produzidos em escala industrial, o qual o autor nomeia de painéis básicos do sistema construtivo proposto.

A Figura 1.3 apresenta uma seção transversal do painel idealizada por El Debs (2016), com as dimensões em milímetros. Na Figura 1.4 é apresentado a aplicação do painel em paredes. 


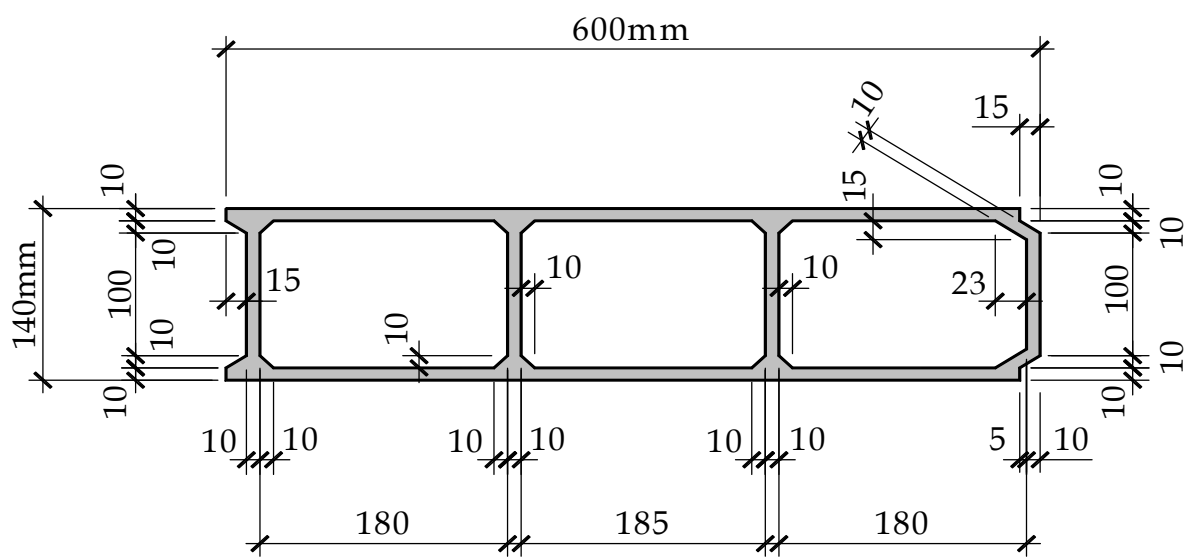

Figura 1.3 - Seção transversal ilustrativa do painel básico com ordem de grandeza das dimensões (El Debs, 2016)

El Debs (2016) ainda apresenta um outro tipo de painel que poderia ser utilizado nas lajes, com algumas adaptações, associado ao concreto moldado no local. Segundo o autor, o sistema estrutural seria de laje nervurada de concreto armado. O painel serviria de elemento de enchimento, propiciando acabamento na parte inferior da laje igual ao das paredes e estaria integrado ao sistema construtivo. A seção transversal desse painel e a seção transversal da laje é apresentada na Figura 1.5.
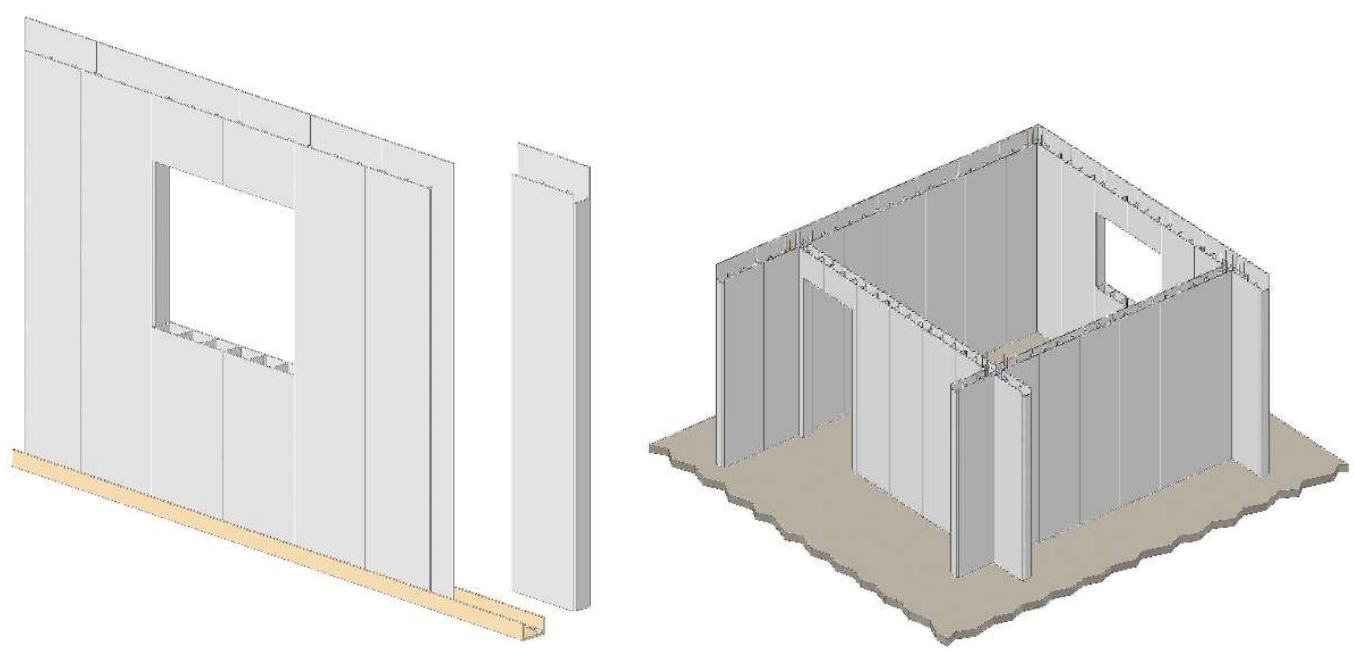

a) parede isolada

b) associação de paredes

Figura 1.4 - Aplicação do painel básico em paredes (El Debs, 2016) 


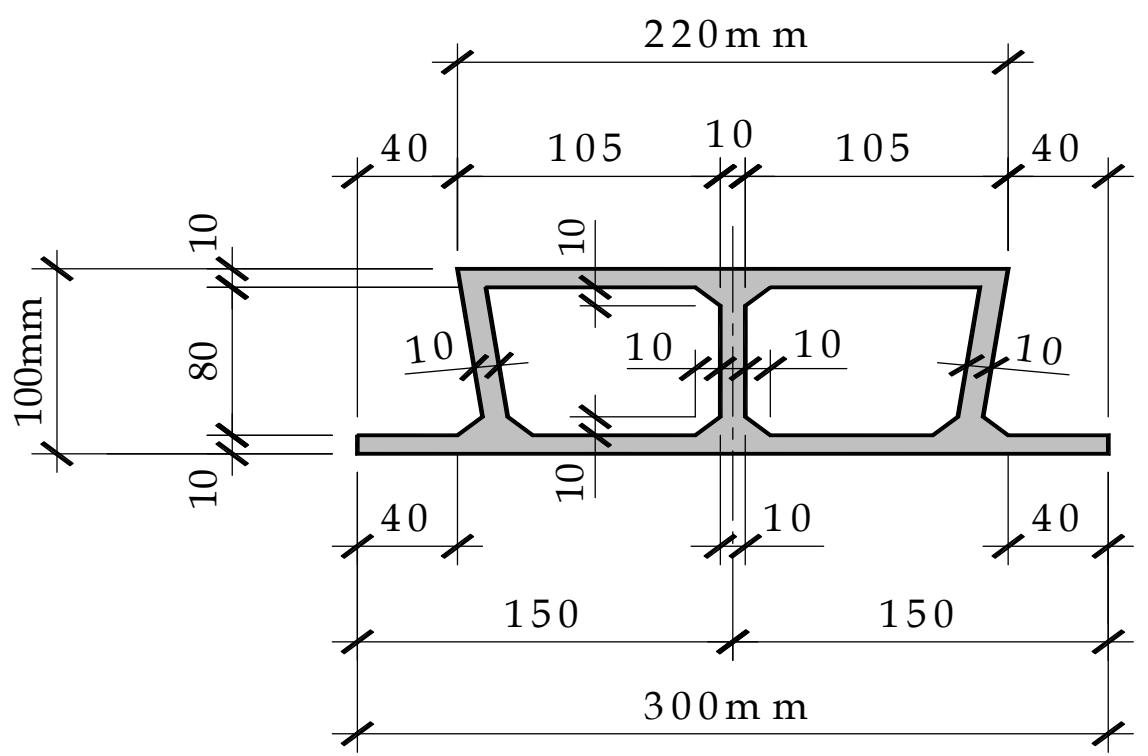

a) Seção transversal ilustrativa com ordem de grandeza das dimensões

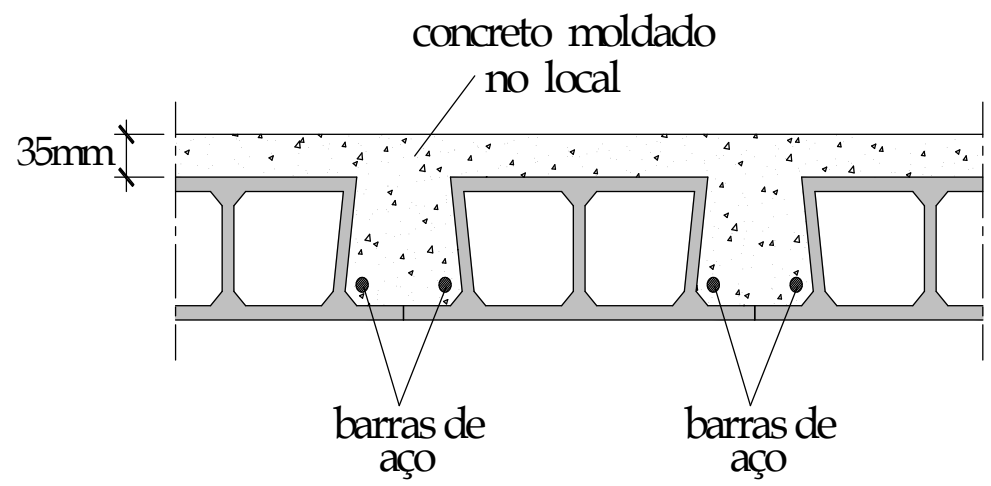

b) Seção transversal da laje

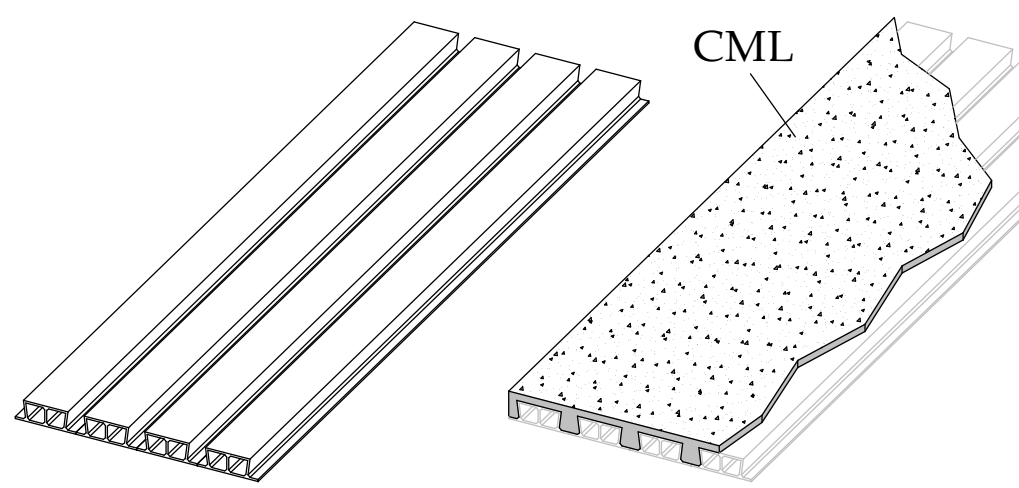

Figura 1.5 - Seção transversal prevista para lajes e sua aplicação associada a concreto moldado no local (El Debs, 2016) 
El Debs (2016) cita uma série de caracteteríscas que justificam o sistema construtivo proposto, sendo elas:

a) Em função das pequenas espessuras dos painéis, o consumo de matérias é baixo, o que resulta em baixa quantidade de cimento, mesmo que o consumo por metro cúbico de cimento seja alto. A redução do cimento é, reconhecidamente, muito importante em para redução de $\mathrm{CO} 2$ e, portanto, em relação à sustentabilidade.

b) Em função da padronização, a produção dos painéis básicos seria bastante apropriada para ser feita em fábrica, com alto grau de mecanização.

c) A produção dos componentes pré-fabricados das paredes, a partir dos painéis básicos, também nas fábricas, agregaria os benefícios do ambiente industrial.

d) Os componentes pré-fabricados das paredes poderiam incorporar, de forma integrada, grande parte das instalações na fábrica.

e) A proposta construtiva conduz a uma racionalização da construção no local, em particular em relação à estrutura, aos fechamentos e às instalações.

f) Em principio, não haveria necessidade de revestimentos nas paredes e forros, em função do acabamento previsto para as duas faces dos painéis, embora possa ser necessária a aplicação de mastique nas juntas. A eliminação do material de revestimento também seria benéfica em relação à sustentabilidade.

g) Em principio, a forma das paredes pode trazer benefícios para o conforto térmico da construção.

h) A proposta poderia ser aplicada em construções com um ou mais andares. Naturalmente, é necessário projetar os pilares/pilaretes e vigas/cintas que são moldadas nos nichos feitos nos painéis, mas é possível prever o seu empregado para edifícios relativamente altos.

Embora, o sistema construtivo proposto apresente as vantagens citadas acima, a proposta necessita de desenvolver algumas partes como afirma El Debs (2016), sendo:

a) Desenvolver os sistema de produção dos painéis de forma mecanizada em conjunto com uma dosagem do material cimenticio com elevado teor de fibras.

b) Embora estejam delineadas a interação das varias partes que compoem o sistema construtivo, seria necessário detalhar e compatibilizar todas as instalações e caixilhos com as paredes e lajes. 
O presente trabalho propões o desenvolvimento de um material cimentício que será composto dos seguintes elementos: cimento, agregado miúdo (areia), superplastificante e fibras curtas de polipropileno. A adição de fibras curtas ao concreto melhora, em geral, as resistências ao impacto e a tração do compósito endurecido, bem como aumenta a sua tenacidade. Por outro lado, em altos teores, as fibras reduzem significativamente a trabalhabilidade da mistura e podem incorporar ar ao material endurecido, o que promove também a redução do módulo de elasticidade.

$\mathrm{Na}$ tentativa de desenvolver um material com resistência e rigidez adequadas ao uso estrutural, com reduzido peso do elemento estrutural, idealizou-se painéis alveolares de concreto de fina espessura. Esse painel poderá ser utilizado para paredes e lajes, permitindo que sejam realizados cortes sem dificuldades para atender a adaptações e possibilitar aberturas.

Entre as vantagens da geometria do painel, podem ser citadas: sugere uma melhoria quanto ao isolamento térmico; as instalações elétricas, hidráulicas e sanitárias podem passar pelos alvéolos; o acabamento final do painel possibilita que a pintura seja aplicada diretamente; e, no caso de construções de pequeno porte, os painéis poderiam ser montados manualmente.

\subsection{Objetivos}

O objetivo geral da pesquisa é estudar a composição do concreto reforçado com alto teor de fibras de polipropileno com características apropriadas para a moldagem do painel alveolar com paredes finas, assim como avaliar seu comportamento estrutural.

Os objetivos específicos são:

- Desenvolver material cimentício para a moldagem do painel, composto por cimento, areia, fibras de polipropileno (com taxas superiores a 1\%), com resistência à compressão superior a $35 \mathrm{MPa}$;

- Estudar as propriedades mecânicas do compósito desenvolvido através de análise de ensaios laboratoriais;

- Analisar o comportamento quanto a flexão e carga concentrada, do corpo de prova do painel de concreto reforçado com alto teor de fibras de polipropileno. 


\subsection{Justificativa}

Na busca de novas tecnologias de construção, procura-se desenvolver um material capaz de atender as perspectivas do mercado com soluções inovadoras que reduzam o tempo de construção, sendo econômicas sob o ponto de vista de tempo como também de quantidade de material empregado para sua aplicação.

Para esse propósito será estudado o comportamento estrutural de painel de concreto pré-moldado reforçado com fibras de polipropileno. Esses podem ser usados como elemento de vedação e laje, principalmente em edificações habitacionais.

Observa-se da literatura que:

- Existe um pequeno número de pesquisas do comportamento estrutural do concreto reforçado com fibras de polipropileno com frações volumétricas de fibras moderada (entre $1 \%$ e $2 \%$ ) e alta (maior que $2 \%$ );

- A utilização das fibras de polipropileno no concreto indica um aumento das propriedades mecânicas do concreto, entre elas a resistência à tração, resistência à flexão, resistência ao impacto, e tenacidade. Além disso, Kim et al. (2010) obteve em seus ensaios experimentais, resistências à compressão superiores a $30 \mathrm{MPa}$, com um máximo de 38,3 MPa com volume de fibras de polipropileno de 3\%;

- Novas tecnologias impulsionam a utilização de elementos de baixo peso estrutural, além da facilidade e rapidez de construção. A geometria do painel de parede fina com a presença de alvéolos e inclusão de fibras de polipropileno, que possuem peso específico e baixo custo, contribui significativamente não só em tornar a estrutura mais leve como também mais econômica.

Com base nos aspectos citados nota-se a relevância do estudo do material cimentício a ser aplicado nos painéis, pois existem diversos tipos de fibras que estão disponíveis no mercado que propiciam um ganho nas propriedades mecânicas dos compósitos produzidos. 


\section{REVISÃO BIBLIOGRÁFICA}

\subsection{Concreto reforçado com fibras}

A combinação de material baseado em cimento Portland e de polímeros forma um compósito que apresenta características como resistência mecânica, módulo de elasticidade, ductilidade, tenacidade e comportamento pós-fissuração mais apropriadas, quando comparadas às propriedades dos materiais isoladamente.

Os materiais que podem compor um compósito podem ser classificados em dois tipos: a matriz e o elemento de reforço. A matriz é o que confere estrutura ao material compósito, preenchendo os espaços vazios que ficam entre os materiais reforços e mantendo-os em suas posições relativas. Os elementos de reforço são os que realçam as propriedades mecânicas do material compósito como um todo.

Segundo ${ }^{1}$ Budinski (1996, apud ARAÚJO, 2005), os materiais compósitos provenientes de combinações de polímeros e materiais cerâmicos são os mais importantes. Os materiais baseados em cimento Portland são considerados como materiais cerâmicos por apresentarem propriedades típicas a este grupo de materiais, como, por exemplo, alta rigidez, fragilidade, baixa resistência à tração e tendência de fissuração por secagem.

Quanto às propriedades mecânicas, os polímeros são caracterizados por possuírem ductilidade variável, moderada resistência à tração e baixo módulo de elasticidade.

Bentur e Mindess (2007) afirmam que a presença de fibras na argamassa promove ao concreto um ganho de resistência à tração, maior capacidade de deformação e aumento da tenacidade. Além dessas propriedades, Choi e Yuan (2004) adicionam o aumento da resistência ao impacto, resistência à flexão e do módulo de ruptura. Ainda segundo Bentur e Mindess (2007), a adição de fibras ao concreto tem pouco ou nenhum efeito sobre a resistência a compressão e no módulo de elasticidade. A Figura 2.1 mostra curvas carga-deformação para o concreto convencional e o concreto reforçado com fibras (fiber reinforced concrete $-F R C$ ) e a Figura 2.2 evidencia o mecanismo de aumento de tenacidade à flexão do concreto com fibras.

1 BUDINSKI, K.G. Engineering materials: properties and selection. New Jersey: Prentice Hall International., 5ed, 1996. 653p. 


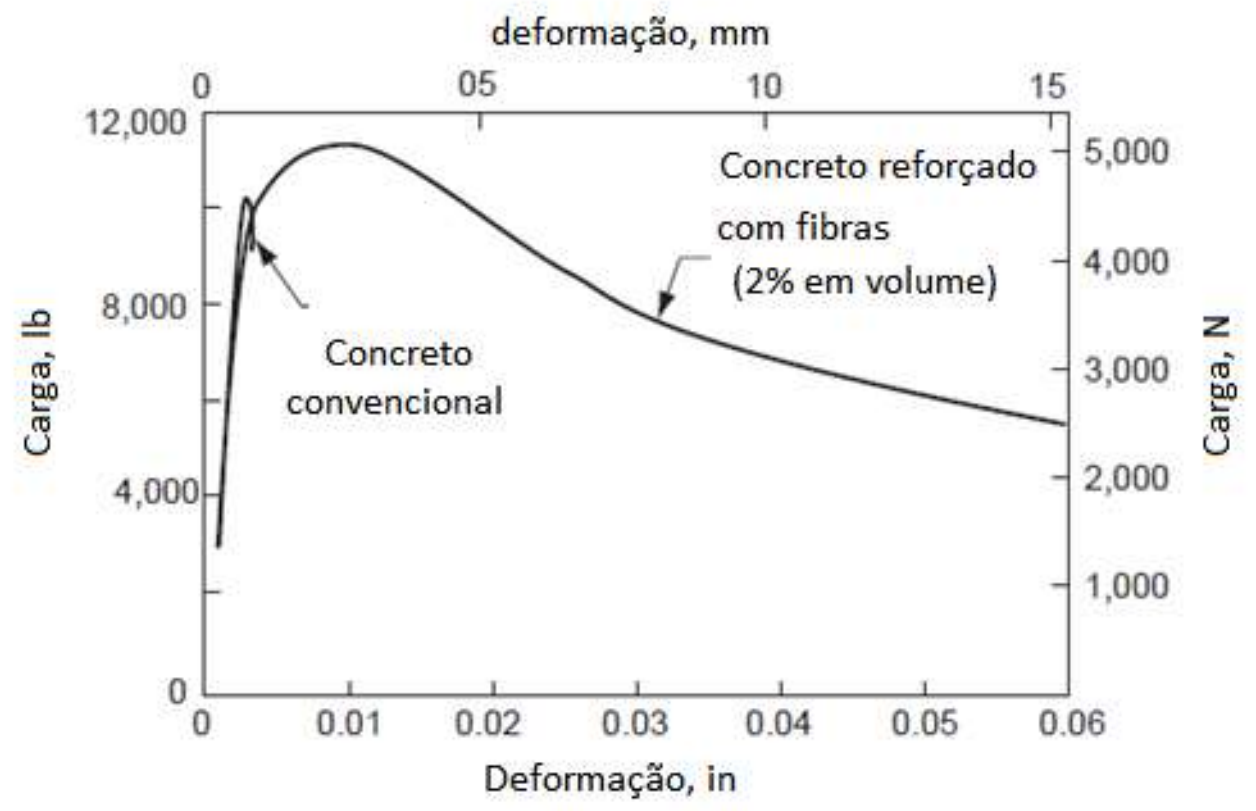

Figura 2.1 - Comportamento carga-deformação de concreto convencional e FRC ( ${ }^{2}$ Hanna, A.C., 1977 apud Mehta e Monteiro, 2008)

No ensaio de determinação da resistência à flexão, a ruptura do concreto convencional ocorre de forma repentina, assim que a deformação correspondente supera a resistência última à flexão. Já o FRC é capaz de suportar cargas consideráveis, mesmo com deformações superiores à deformação na fratura do concreto convencional. Portanto, um corpo de prova de FRC após o início da primeira fissuração não se rompe, diferentemente do concreto convencional.

As propriedades mecânicas do concreto podem ser melhoradas por fibras curtas discretas aleatoriamente orientadas, que previnem ou controlam a formação e a propagação de fissuras. A fibra induz uma distribuição homogênea das tensões no concreto, o que provoca uma melhor exploração da matriz de elevada resistência (Gencel et al., 2011).

2 Hanna. A.C., Steel Fiber Reinforced Concrete Properties and Resurfacing Applications, Portand Cement Association, Stokie, IL, Report RD049.01P, 1977. 


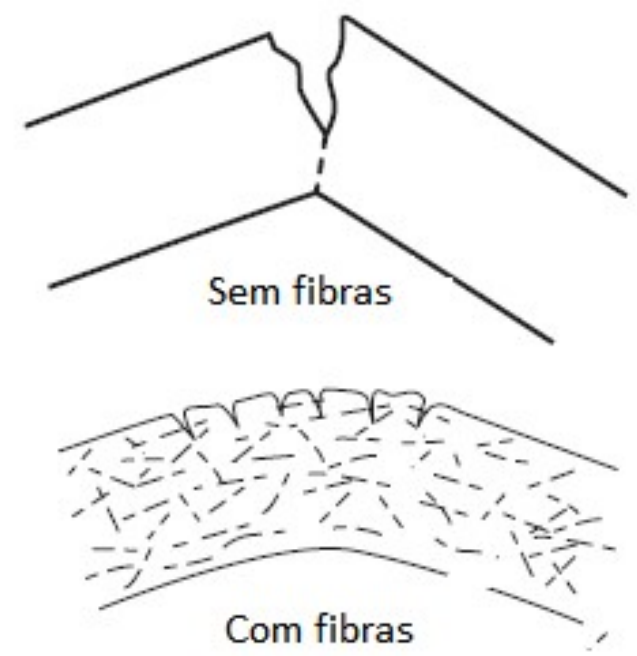

Figura 2.2 - Mecanismo de aumento de tenacidade à flexão do concreto com fibra ( ${ }^{3}$ Johnson, 1980 apud Mehta e Monteiro, 2008)

De acordo com Kim et al. (2010) vários tipos de produtos de concreto pré-moldado, como concreto reforçado com fibras (FRC) e concreto leve, têm sido desenvolvidos e verificados experimentalmente. Alguns deles têm sido aplicados na construção de estruturas de grande escala. Concretos de agregado leve oferecem resistência, redução da carga permanente, e condutividade térmica, mas apresentam limitada capacidade para absorver a energia de sismos. Em contraste, o FRC tem uma maior capacidade de absorção de energia, ou seja, tenacidade.

Segundo Mehta e Monteiro (2008) a fração volumétrica assim como o tipo de fibra apresenta efeitos significativos nas propriedades do concreto reforçado com fibras. Quanto à fração volumétrica, pode-se classificar o FRC em:

- Baixa fração volumétrica $(<1 \%)$ : utilizada quando se deseja reduzir a fissuração decorrida da retração, usualmente aplicada em estruturas onde há grande superfície exposta, como por exemplo, lajes de pavimentos.

- Moderada fração volumétrica (entre 1 e 2\%): propriedades como módulo de ruptura, tenacidade e resistência ao impacto apresentam significativos aumentos nessa fração volumétrica.

${ }^{3}$ Johnson, C.D., in Progress in Concrete Technology, Malhotra, V.M., ed., CANMET, Ottawa, pp.452$504,1980$. 
- Alta fração volumétrica ( $>2 \%$ ): a presença de fibras nessa fração volumétrica leva ao endurecimento por deformação dos compósitos. Devido ao seu melhor desempenho, esses compósitos são considerados de alto desempenho.

Segundo Kakooei et al. (2012), os resultados de ensaios conduzidos por pesquisadores mostram que a resistência à compressão, tração e flexão apresentam aumento com grande volume de fibras. Uma das mais importantes razões para o reforço do concreto com fibras é elevar a estabilização da tensão e da elasticidade.

Em geral, o desempenho de concreto reforçado depende de formulações, bem como características de fibras, incluindo o tipo, geometria, distribuição, orientação e concentração. Muitos tipos diferentes de fibras, tais como metálicas, poliméricas, revestidas, não revestidas ou modificadas por irradiação, foram utilizadas em engenharia de concreto para as suas vantagens específicas (Gencel et al., 2011).

\subsection{Fibras de polipropileno}

Entre as fibras usadas para reforço de materiais cimentícios, o uso de fibras sintéticas (poliméricas), vem ganhando importância, com destaque especial às de polipropileno, extensivamente utilizadas. As propriedades de algumas fibras sintéticas comuns são apresentadas na Tabela 2.1 .

As fibras de polipropileno são produzidas a partir da resina de polipropileno do tipo homopolímero em vários tamanhos e formas, e com diferentes propriedades. As principais vantagens dessas fibras são relativo alto ponto de fusão $\left(165^{\circ} \mathrm{C}\right)$, resistência a álcalis e o baixo preço do material. Em contrapartida suas desvantagens são sua baixa resistência ao fogo, sensibilidade à luz do sol e oxigênio, baixo módulo de elasticidade e fraca aderência com a matriz cimentícia (Bentur e Mindess, 2007).

Como o peso específico das fibras de polipropileno é baixo, um alto teor de fibras também reduz o peso do concreto. Isso é um efeito oposto do que acontece com as fibras de aço, onde sua inclusão no concreto aumenta o peso do elemento estrutural. 
Tabela 2.1 - Propriedades típicas das fibras sintéticas (Bentur e Mindess, 2007)

\begin{tabular}{|c|c|c|c|c|c|}
\hline Tipo de Fibra & $\begin{array}{l}\text { Diâmentro } \\
(\mathrm{mm})\end{array}$ & $\begin{array}{c}\text { Densidade } \\
\left(\mathrm{g} / \mathrm{cm}^{3}\right)\end{array}$ & $\begin{array}{c}\text { Resistência à } \\
\text { Tração (GPa) }\end{array}$ & $\begin{array}{c}\text { Módulo de } \\
\text { Elasticidade } \\
\text { (GPa) }\end{array}$ & $\begin{array}{l}\text { Alongame- } \\
\text { nto último } \\
\text { (\%) }\end{array}$ \\
\hline Acrílica & $20-350$ & $1,16-1,18$ & $0,2-1,0$ & $14-19$ & $10-50$ \\
\hline Aramida (Kevlar) & $10-12$ & 1,44 & $2,3-3,5$ & $63-120$ & $2-4,5$ \\
\hline Carbon (PAN) & $8-9$ & $1,6-1,7$ & $2,5-4,0$ & $230-380$ & $0,5-1,5$ \\
\hline Carbon (Pich) & $9-18$ & $1,6-1,21$ & $0,5-3,1$ & $30-480$ & $0,5-2,4$ \\
\hline Nylon & $23-400$ & 1,14 & $0,75-1,0$ & $4,1-5,2$ & $16-20$ \\
\hline Poliéster & $10-200$ & $1,34-1,39$ & $0,23-1,2$ & $10-18$ & $10-50$ \\
\hline Polietileno & $25-1000$ & $0,92-0,96$ & $0,08-0,6$ & 5 & $3-100$ \\
\hline Poliolefina & $150-635$ & 0,91 & 275 & 2,7 & 15 \\
\hline Polipropileno & $20-400$ & $0,9-0,95$ & $0,45-0,76$ & $3,5-10$ & $15-25$ \\
\hline PVA & $14-650$ & 1,3 & $0,8-1,5$ & $29-36$ & 5,7 \\
\hline Aço & $100-1000$ & 7,84 & $0,5-2,6$ & 210 & $0,5-3,5$ \\
\hline
\end{tabular}

As fibras de polipropileno usadas em reforço da matriz cimentícia, podem se apresentar em três diferentes formas geométricas: monofilamentadas, multifilamentadas (filme fibrilado) e fita extrusada. As três formas são usadas com sucesso para reforço de argamassa e concreto. Segundo Bentur e Mindess (2007), as fibras monofilamentadas e fibriladas possuem essencialmente a mesma resistência e módulo de elasticidade. Entretanto, para o combate de fissuras são sugeridas as fibras monofilamentadas, que são mais efetivas do que as fibras fibriladas.

\subsection{Concreto reforçado com fibras de polipropileno}

A capacidade do reforço após a fissuração da matriz tem relação direta com o teor de fibras. Logo, aumentando a quantidade de fibras por unidade de volume do compósito, pode ocorrer o aumento da sua capacidade resistente e sua tenacidade. Isso porque o aumento da quantidade de fibras faz com que ocorra o aumento da quantidade de pontes de transferência de tensões nas fissuras (Bentur e Mindess, 2007).

Shah (1991) observou que a adição de baixos teores de fibras de polipropileno ao 
concreto, contribui para evitar a propagação das microfissuras. De acordo com Jiang e Roy (1992) a utilização de alto teor de fibras em polipropileno (cerca de $2 \%$ em volume de concreto), não só evita a propagação como também pode desviar as microfissuras.

Quanto à degradação, as fibras poliméricas quando comparadas a outros tipos de fibras são mais vantajosas, pois não sofrem ataques de micro-organismos, como é o caso da fibra vegetal; corrosão, no caso de fibras de aço; degradação em meio alcalino do cimento, no caso de fibras vegetal e de vidro.

Zeiml et al.(2006) menciona que o uso de fibras de polipropileno pode melhorar o comportamento da fissuração do concreto. Segundo Kakooei et al. (2012), em concreto comum, onde é necessária vibração, o melhor e mais aceitável método de prevenir a formação de fissuras causadas pela retração da pasta de cimento é o uso de fibras, particularmente artificiais (sintéticas), como é o caso das fibras de polipropileno.

Mogre e Parbat (2012), afirmam que o uso de alta fração volumétrica de fibras de polipropileno para o concreto é vantajoso, pois:

- Inibe fissuras por retração plástica;

- Aumenta a resistência à tração;

- Aumenta a resistência à flexão;

- Aumenta a resistência à fadiga;

- Aumenta em geral a durabilidade e a resistência à fissuração;

- Impede o lascamento;

- Fornece resistência ao impacto;

- Fornece resistência à abrasão;

- Aumenta a tenacidade.

Com o aumento do volume das fibras de polipropileno, o abatimento da mistura diminui. Logo, para elementos de concreto com alto teor de fibras, Mogre e Parbat (2012) recomendam o uso de super plastificantes para melhorar a trabalhabilidade.

Song, Hwang e Sheu (2005) demonstram experimentalmente que a adição de fibras de polipropileno com frações moderadas (1\% em volume de concreto) aumentou em 5,8\% a resistência à compressão, 9,7\% a resistência à tração diametral e 1,5\% a resistência à tração na flexão. Estes resultados não são expressivos, levando-se em consideração as médias e desvios padrões obtidos. A Tabela 2.2 abaixo apresenta os resultados obtidos nos ensaios de resistência para o concreto reforçado com fibras de polipropileno e concreto convencional. 
Tabela 2.2 - Resultado dos ensaios de resistência (Song, Hwang e Sheu, 2004)

\begin{tabular}{clcccc}
\hline Tipo de concreto & Estatística descritiva & $\begin{array}{c}\text { Resistência à } \\
\text { compressão } \\
(\mathbf{M P a})\end{array}$ & $\begin{array}{c}\text { Resistência à } \\
\text { tração } \\
\text { diametral } \\
(\mathbf{M P a})\end{array}$ & $\begin{array}{c}\text { Resistência } \\
\text { à tração na } \\
\text { flexão } \\
(\mathbf{M P a})\end{array}$ & Slump (cm) \\
\hline $\begin{array}{c}\text { Concreto } \\
\text { reforçado com } \\
\text { fibras de }\end{array}$ & Média & 24,35 & 2,38 & 5,98 & \\
polipropileno & Coeficiente de variação (\%) & 7,5 & 6,16 & 0,36 & 12 \\
\hline $\begin{array}{c}\text { Concreto } \\
\text { convencional }\end{array}$ & Média & 23,02 & 2,17 & 6,0 & \\
& Desvio Padrão & 1,77 & 0,15 & 0,36 & 16 \\
\hline
\end{tabular}

Kakooei et al. (2012) demonstra através de ensaios experimentais que amostras de concreto com fibras de polipropileno têm menor permeabilidade em comparação com as amostras sem fibras. Isto porque as fibras previnem o crescimento de fissuras no concreto pela formação das pontes de ligação. Quanto à resistividade elétrica, as amostras de concreto com frações de fibra de $1 \mathrm{~kg} / \mathrm{m}^{3}$ e $2 \mathrm{~kg} / \mathrm{m}^{3}$ têm valores mais elevados em comparação com as sem fibras, que afetam diretamente a redução da corrosão das armaduras.

Hassanpour, Shafigh e Mahmud (2012) estudaram o comportamento mecânico da adição de baixo teor de fibras de polipropileno ao concreto leve (LWAC - Light Weight Agregate Concrete). Os ensaios experimentais mostraram que não há praticamente nenhum efeito sobre a resistência à compressão e módulo de elasticidade, porém notou-se indícios de aumento de resistência à tração, flexão e tenacidade, quando comparados ao concreto convencional.

Kim et al.(2010) realizaram ensaios em concretos utilizando fibras de polipropileno, com frações em volume de 0,1,2, 3 e 4\%, argila expandida como agregado graúdo e agente de auto adensamento. A Tabela 2.3 apresenta os resultados do estudo das propriedades mecânicas do material. O módulo de elasticidade parece ser pouco afetado pelo volume de fibras, (com exceção dos resultados obtidos com teor de $1 \%$ de fibras). $\mathrm{O}$ índice de tenacidade é definido, segundo os mesmos autores, como a razão entre área sob a curva de tensão-deformação do concreto reforçado com fibras e do concreto convencional (sem reforço de fibras) até uma deformação de 0,015. A Figura 2.3 mostra o gráfico de tensão-deformação dos resultados obtidos para os diferentes volumes de fibras. 


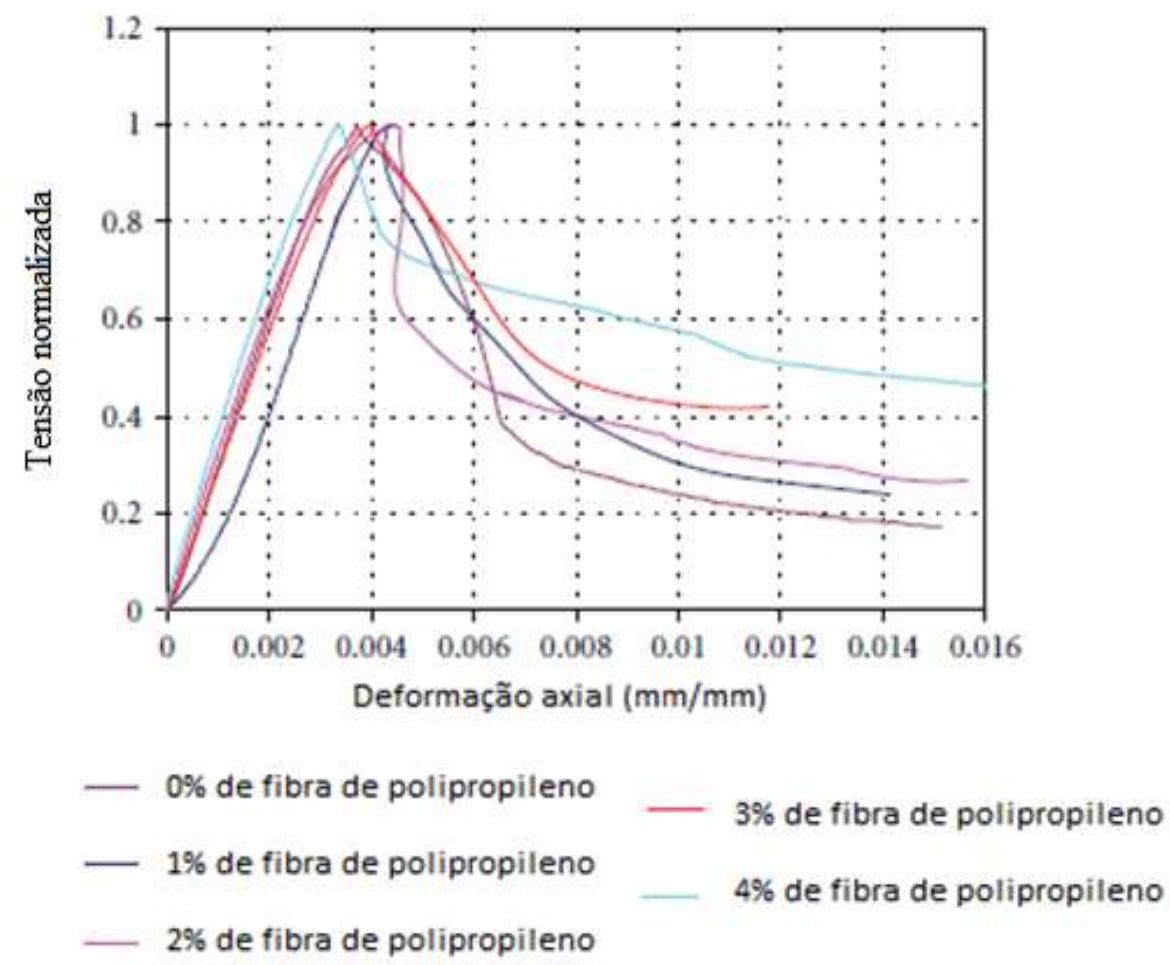

Figura 2.3 - Curva tensão-deformação do concreto para os diferentes volumes de fibras de polipropileno (Kim et al., 2010)

Tabela 2.3 - Propriedades do concreto leve reforçado com fibras de polipropileno (Kim et al., 2010)

\begin{tabular}{|c|c|c|c|c|c|}
\hline $\begin{array}{c}\text { Volume } \\
\text { de Fibras } \\
(\%)\end{array}$ & $\begin{array}{c}\text { Massa } \\
\text { Específica } \\
\left(\mathrm{kg} / \mathbf{m}^{3}\right)\end{array}$ & $\begin{array}{c}\text { Resistência à } \\
\text { Compressão } \\
\text { (MPa) }\end{array}$ & $\begin{array}{l}\text { Deformação axial } \\
\text { no pico }(\mathrm{mm} / \mathbf{m m})\end{array}$ & $\begin{array}{c}\text { Módulo de } \\
\text { elasticidade (GPa) }\end{array}$ & $\begin{array}{c}\text { Índice de } \\
\text { tenacidade }\end{array}$ \\
\hline 0 & 1473,7 & 32,8 & 0,0037 & 10,8 & 1,00 \\
\hline 1 & 1457,7 & 31,5 & 0,0044 & 6,6 & 1,03 \\
\hline 2 & 1489,7 & 34,7 & 0,0044 & 11,2 & 1,26 \\
\hline 3 & 1473,7 & 38,3 & 0,0040 & 11,0 & 1,29 \\
\hline 4 & 1473,7 & 33,2 & 0,0034 & 12,0 & 1,33 \\
\hline
\end{tabular}




\section{MATERIAIS UTILIZADOS}

Neste capítulo, apresentam-se os materiais utilizados nessa pesquisa, sua origem e suas características.

\subsection{Cimento Portland}

Cimento Portland é definido, segundo a norma ABNT NBR 5732:1991, como um aglomerante hidráulico obtido pela moagem de clínquer Portland ao qual se adiciona, durante a operação, a quantidade necessária de uma ou mais formas de sulfato de cálcio. De acordo com a mesma norma, é permitido adicionar durante a moagem, materiais pozolânicos, escórias granuladas de alto-forno e/ou materiais carbonáticos, em teores especificados.

Para o desenvolvimento da pesquisa será utilizado o cimento Portland do tipo CP-VARI da fabricante HOLCIM S.A., possibilitando rápida desmoldagem e rápido ganho de resistência nas primeiras idades.

As propriedades do cimento utilizado na pesquisa são apresentadas na Tabela 3.1.

Tabela 3.1 - Características do cimento Portland utilizado (HOLCIM S.A.)

\begin{tabular}{ccc}
\hline Características & Unidade & Valor \\
\hline Massa específica & $\mathrm{g} / \mathrm{cm}^{3}$ & 3,12 \\
Finura Blaine & $\mathrm{cm}^{2} / \mathrm{g}$ & 4687 \\
Início de pega & $\mathrm{min}$ & 130 \\
Fim de pega & $\mathrm{min}$ & 210 \\
Resistência (1 dia) & $\mathrm{MPa}$ & 27,7 \\
Resistência (3 dias) & $\mathrm{MPa}$ & 42 \\
Resistência (7 dias) & $\mathrm{MPa}$ & 46,7 \\
Resistência (28 dias) & $\mathrm{MPa}$ & 56,1 \\
\hline
\end{tabular}

\subsection{Areia}

A areia utilizada para a produção dos painéis alveolares e do material de caracterização é proveniente do rio Mogi Guaçú, no estado de São Paulo, e é a mesma que foi usada por Ditz (2015). 
Para sua caracterização, seguiu-se os prescritos nas publicações ABNT NBR 7251:1982, ABNT NBR 9776:1987 e ABNT NBR NM 248:2003. A Figura 3.1 apresenta a composição granulométrica da areia e a massa específica e unitária são apresentadas na Tabela 3.2 .

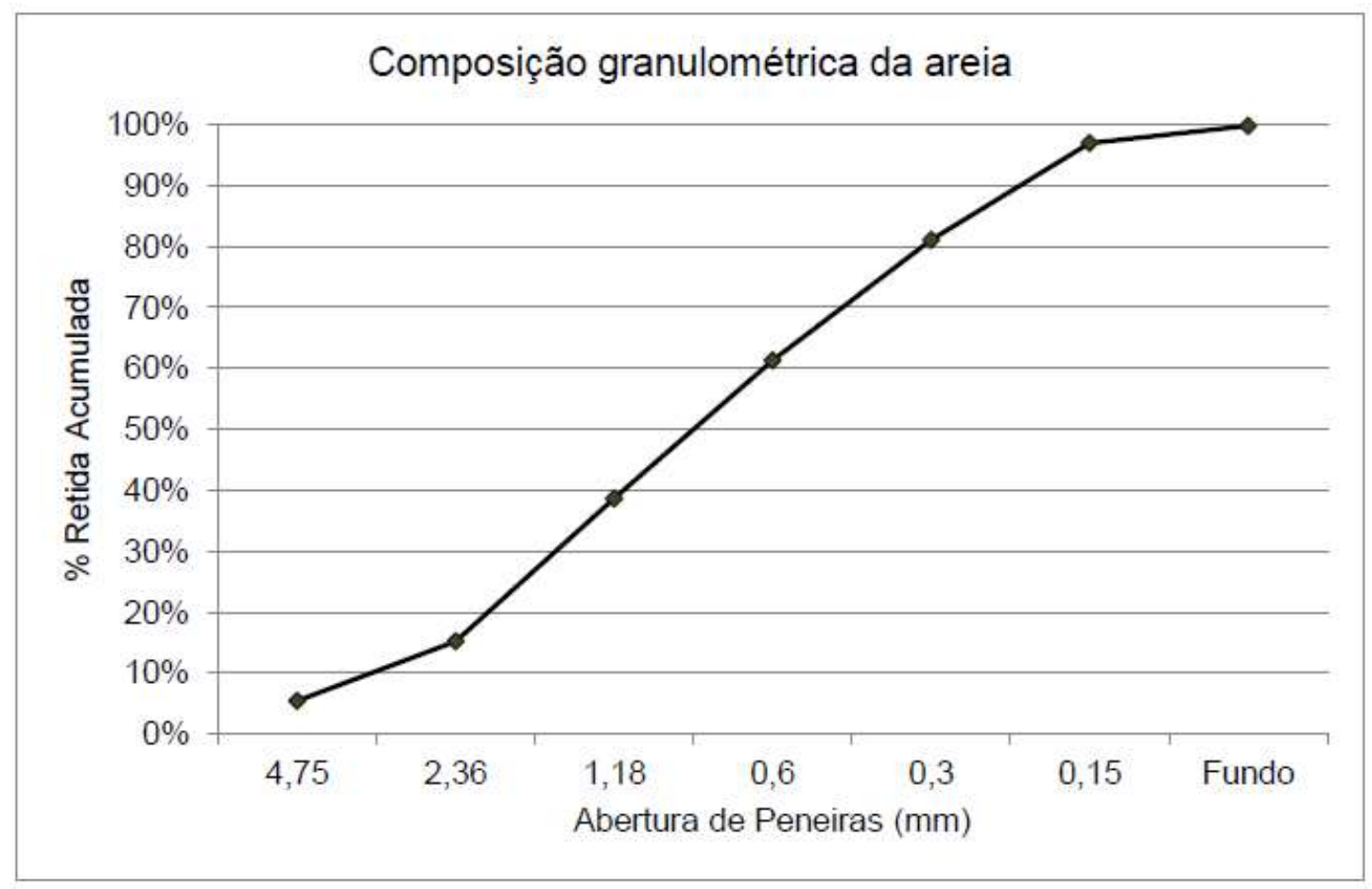

Figura 3.1 - Curva granulométrica da areia (Fonte: Autor)

Tabela 3.2 - Massa específica e massa unitária da areia utilizada na pesquisa

\begin{tabular}{cc}
\hline Propriedadade & Valor \\
\hline Massa específica $\left(\mathrm{g} / \mathrm{cm}^{3}\right)$ & 2,63 \\
Massa unitária $\left(\mathrm{g} / \mathrm{cm}^{3}\right)$ & 1,58 \\
\hline
\end{tabular}

\subsection{Fibras de poliproprileno}

As fibras de polipropileno utilizadas nesta pesquisa foram fornecidas pela empresa BRASILIT-Saint Gobain (Figura 3.2).

As propriedades das fibras estão expostas na Tabela 3.3. 
Tabela 3.3 - Propriedades das fibras de polipropileno (BRASILIT-Saint Gobain)

\begin{tabular}{ccc}
\hline Características & Unidade & Valor \\
\hline Massa específica & $\mathrm{g} / \mathrm{cm}^{3}$ & 0,91 \\
Diâmetro & $\mu \mathrm{m}$ & 12 \\
Comprimento & $\mathrm{mm}$ & 10 \\
Alongamento & $\%$ & 21 \\
Ponto de fusão & ${ }^{\circ} \mathrm{C}$ & 170 \\
\hline
\end{tabular}

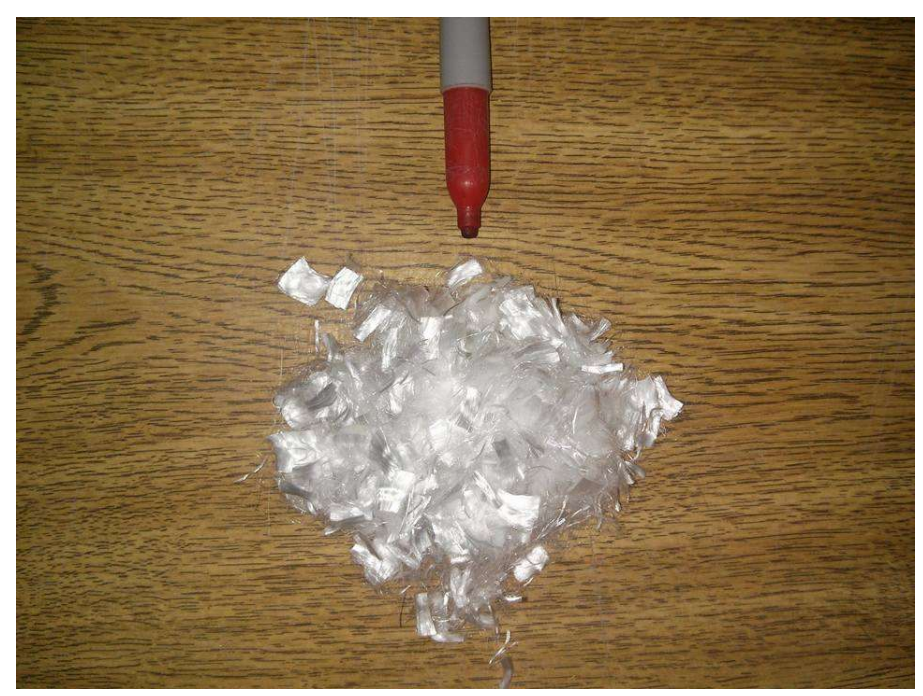

Figura 3.2 - Fibra de polipropileno utilizada na pesquisa (BRASILIT - Saint Gobain - Fonte: Autor)

\subsection{Aditivo super plastificante}

A adição de fibras de polipropileno reduz significativamente a trabalhabilidade da mistura fresca do compósito de cimento. Como alternativa para melhorar a trabalhabilidade, foi adicionado às misturas o aditivo super plastificante GLENIUM 51, fabricado pela empresa BASF.

As propriedades do super plastificante estão descritas na Tabela 3.4. 
Tabela 3.4 - Propriedades do super plastificante (BASF - GLENIUM 51)

\begin{tabular}{ccc}
\hline Características & Unidade & Valor \\
\hline Aparência & Visual & Líquido branco turvo \\
Base Química & - & Éter policarboxílico \\
$\mathbf{p H}$ & - & $6 \pm 1$ \\
Massa específica & $\mathrm{g} / \mathrm{cm}^{3}$ & $1,087 \pm 0,02$ \\
Teor de sólidos & $\%$ & $30 \pm 1,5$ \\
Viscosidade & $\mathrm{cps}$ & $<150$ \\
\hline
\end{tabular}




\section{PROGRAMA EXPERIMENTAL}

Este capítulo descreve o programa experimental da pesquisa, como as dosagens, os ensaios de caracterização do concreto, procedimentos de montagem dos corpos de prova e os ensaios realizados nos corpos do painel alveolar de parede fina.

Não há na mistura a adição de agregado graúdo, o que caracteriza o concreto utilizado na pesquisa como uma argamassa modificada.

\subsection{Dosagens}

Realizaram-se ensaios de caracterização, de forma preliminar para cada teor de fibras, em três argamassas, diferenciando-se a relação água/cimento, a fim de se obter a que apresentasse o melhor resultado quanto às propriedades mecânicas e trabalhabilidade que estivessem de acordo com o objetivo do trabalho.

Estes ensaios de caracterização consistiam em ensaios de compressão axial e módulo de elasticidade. As variáveis analisadas foram relação água/cimento, valores de 0,35;0,4 e 0,45, e teor de fibras, 0,1 e $2 \%$ em volume de concreto. Todas as misturas tinham relação em massa de cimento/areia de 1:2 e o teor em volume de superplastificante de $2 \%$.

Quanto à trabalhabilidade, misturas com relação água/cimento baixa e alto teor de fibras, acarretaram uma argamassa de difícil manuseio, logo, muito baixa trabalhabilidade, o que, durante a moldagem dos corpos de prova, principalmente dos painéis devido a sua geometria, dificultava um bom adensamento.

Os resultados dos ensaios de resistência à compressão das amostras de 0,35 e 0,4 de relação água/cimento apresentaram divergência significativa com relação às amostras de referência (sem fibras), o que pode ser justificado pelo mau adensamento durante a moldagem dos corpos de prova desses teores, ocasionando quantidade e tamanho de vazios altos.

Depois de realizados os ensaios, a dosagem, que foi utilizada para os demais ensaios é apresentada na Tabela 4.1. Para esse traço, os modelos em que foi ensaiada a resistência à compressão apresentaram valores médios superiores à $35 \mathrm{MPa}$. Os demais resultados do estudo preliminar estão presentes no Anexo A. 
Tabela 4.1 - Traço em massa de argamassa reforçada com fibras de polipropileno ((Fonte: Autor))

\begin{tabular}{ccccc}
\hline Cimento & Areia & Fibras PP (em volume de argamassa) & Super plastificante & Água (total) \\
\hline 1 & 2 & $0,01-0,02$ & 0,02 & 0,45 \\
\hline
\end{tabular}

A Equação 01 representa a expressão para o cálculo do consumo de cimento (C $\left.\mathrm{kg} / \mathrm{m}^{3}\right)$. Na expressão, os índices $\gamma_{c}$ e $\gamma_{a}$ significam, respectivamente, as massas específicas do cimento e da areia em $\mathrm{g} / \mathrm{cm}^{3}$ e os índices $a$ e $h$ indicam o consumo, em relação ao cimento, de areia e água.

$$
C=\frac{1000}{\frac{1}{\gamma_{c}}+\frac{a}{\gamma_{a}}+\frac{f}{\gamma_{\text {fibra }}}+h} \quad \text { Eq. (01) }
$$

Sendo $\gamma_{\mathrm{c}}=3,12 \mathrm{~g} / \mathrm{cm}^{3}, \gamma_{\mathrm{a}}=2,65 \mathrm{~g} / \mathrm{cm}^{3}, \gamma_{\text {fibra }}=0,91 \mathrm{~g} / \mathrm{cm}^{3}, \mathrm{a}=2, \mathrm{f}=0,013 \mathrm{e} \mathrm{h}=0,45$, resulta em um consumo de cimento (C) da argamassa é igual a $649,15 \mathbf{~ k g} / \mathbf{m}^{3}$.

Quanto à ordem de colocação dos materiais na misturadora mecânica, primeiro são adicionados juntamente o cimento e areia, após um pequeno tempo de mistura é adicionada a parte da água, e logo em seguida o superplastificante. Assim que a mistura apresentar adequada plasticidade, são adicionadas as fibras de polipropileno molhadas com o restante de água.

É necessária atenção quanto à quantidade de água, pois segundo o fabricante do superplastificante, $70 \%$ do produto é água, logo na tabela 4.1 o valor de 0,45 para a água representa o valor total.

A Figura 4.1 apresenta a argamassa após a mistura no estado fresco. Devido à adição de alto teor de fibras de polipropileno (2\%), nota-se uma trabalhabilidade muito baixa. A compactação da mistura é realizada em mesa vibratória, além da utilização de um soquete para contribuir para melhor adensamento.

Além dos corpos de prova de painel alveolar com argamassa reforçada com fibras de polipropileno, são produzidas e caracterizadas, através dos mesmos ensaios, argamassas de referência, ou seja, com uma dosagem padrão sem a adição de fibra de polipropileno, para verificar as alterações nas propriedades do compósito. O traço da mistura da argamassa de referência é apresentado na Tabela 4.2. 


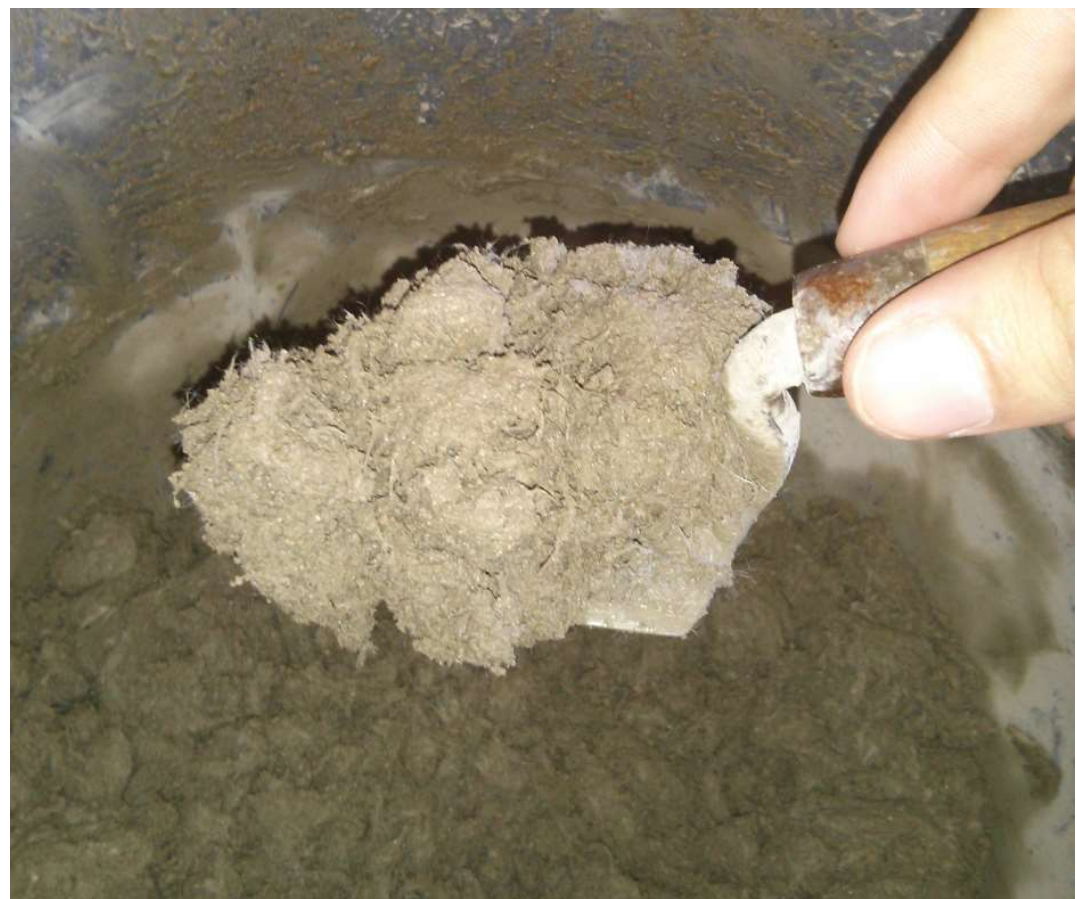

Figura 4.1 - Argamassa com fibras no estado fresco

Tabela 4.2 - Traço em massa da argamassa de referência

\begin{tabular}{cccc}
\hline Cimento & Areia & Super plastificante & Água \\
\hline 1 & 2 & 0,01 & 0,45 \\
\hline
\end{tabular}

A ordem de introdução dos componentes é semelhante à argamassa reforçada com fibras, com exceção apenas da última etapa. Diferentemente da mistura com adição de fibras, a dosagem de referência apresentou excelente trabalhabilidade, sendo uma excelente vantagem para seu lançamento e adensamento.

\subsection{Produção dos corpos de prova de painéis alveolares}

Os painéis alveolares possuem seção transversal com dimensões de 300 mm x 140 mm, conforme apresentado na Figura 4.2. Essas dimensões representam um modelo reduzido semelhante ao modelo proposto por El Debs (2016), conforme apresentado na introdução, nas considerações iniciais.

Devido às configurações dos ensaios, foram produzidos dois tipos de corpos de prova com diferença apenas no seu comprimento. Para os ensaios de carga concentrada, o 
comprimento foi de $600 \mathrm{~mm}$; para o ensaio de flexão, $1200 \mathrm{~mm}$. A geometria dos dois corpos de prova é apresentada na Figura 4.3.
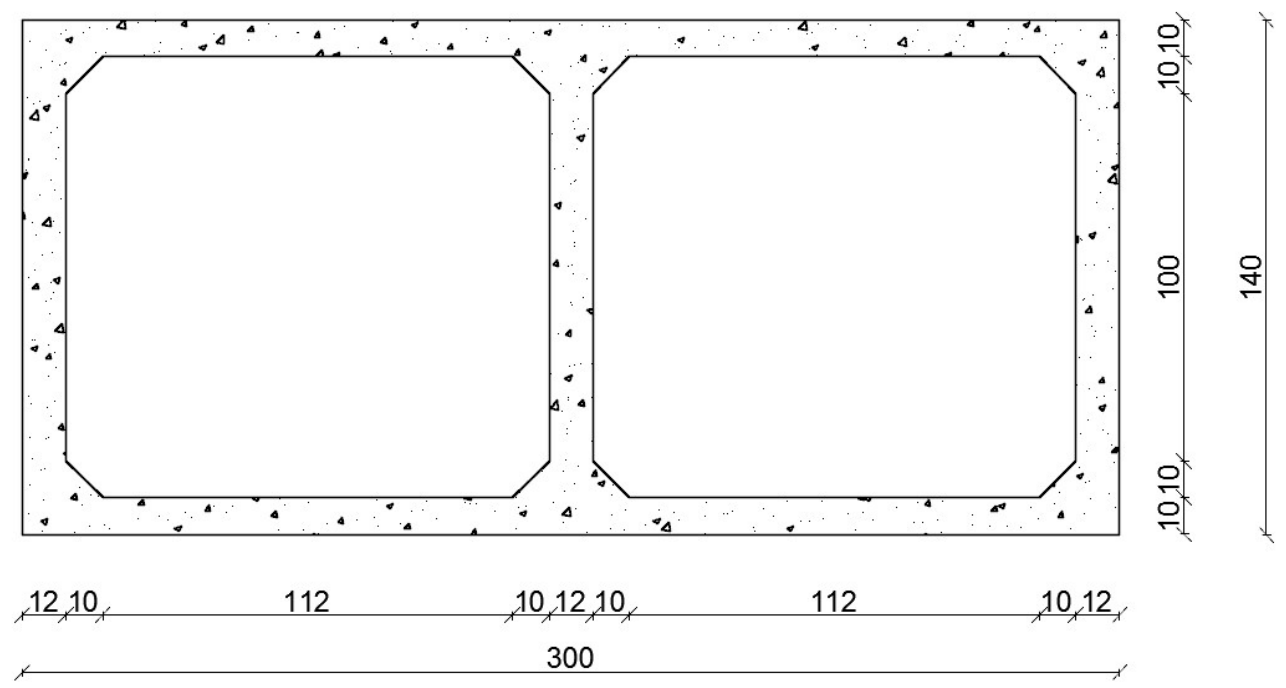

Figura 4.2 -Seção transversal do corpo-de-prova do painel - medidas em milímetros (Fonte: Autor)

A forma dos painéis foi produzida com chapas de madeira compensada naval de 20 $\mathrm{mm}$, chapas de poliestireno $1 \mathrm{~mm}$ para acabamento das faces, além de parafusos e barras roscadas.

Os modelos produzidos na forma tinham comprimento de $1200 \mathrm{~mm}$, correspondendo aos corpos de prova que foram ensaiados à flexão.

Para fabricação dos corpos de prova para o ensaio de carga concentrada, esses eram obtidos pela moldagem na forma do painel de $1200 \mathrm{~mm}$ que era posteriormente cortado na metade do comprimento, produzindo então dois modelos com $600 \mathrm{~mm}$ de comprimento e mesma seção transversal. A Figura 4.4 apresenta o corte do modelo produzido pela moldagem, em dois corpos de prova de comprimento de $600 \mathrm{~mm}$.

Para se obter a forma dos alvéolos, inicialmente utilizou-se cunhas de madeira, mas durante a desmoldagem estas cunhas apresentaram relativa aderência à argamassa e observouse fissurações excessivas no modelo. Por conta disso, resolveu-se substituir essas peças de madeira por peças de poliestireno. $\mathrm{Na}$ etapa de desmoldagem as peças de poliestireno eram facilmente removidas com a utilização de tíner, um solvente para tintas que reage quimicamente com o poliestireno dissolvendo-o.

Devido à baixa trabalhabilidade da argamassa reforçada com fibras, o lançamento do material na forma dos painéis foi feito primeiramente preenchendo-se o fundo, em seguida acopla-se a parte superior da forma e então preenche-se as duas laterais e o trecho central para 
finalizar a parte superior. Utilizou-se um sarrafo para nivelar e ter o acabamento na superfície superior. A Figura 4.5 apresenta as etapas da moldagem.

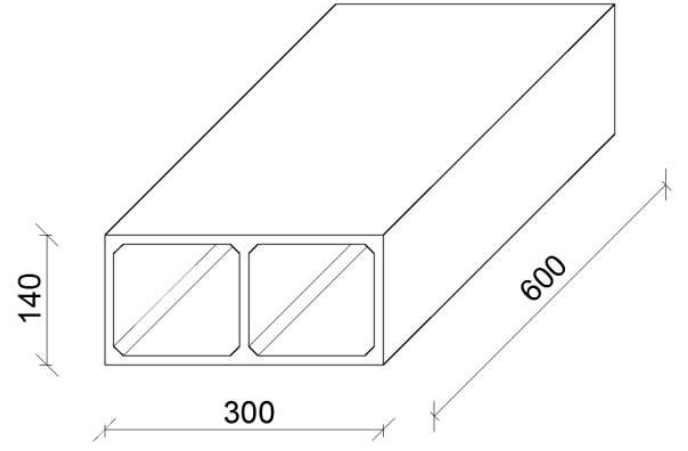

(a)

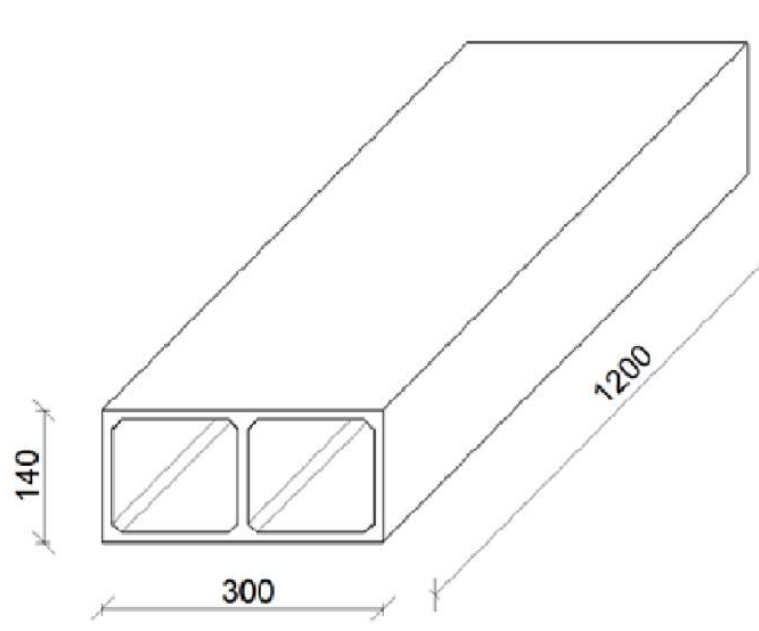

(b)

Figura 4.3 - Geometria do corpo-de-prova para ensaios de carga concentrada (a) e resistência à flexão (b) medidas em milímetros (Fonte: Autor)

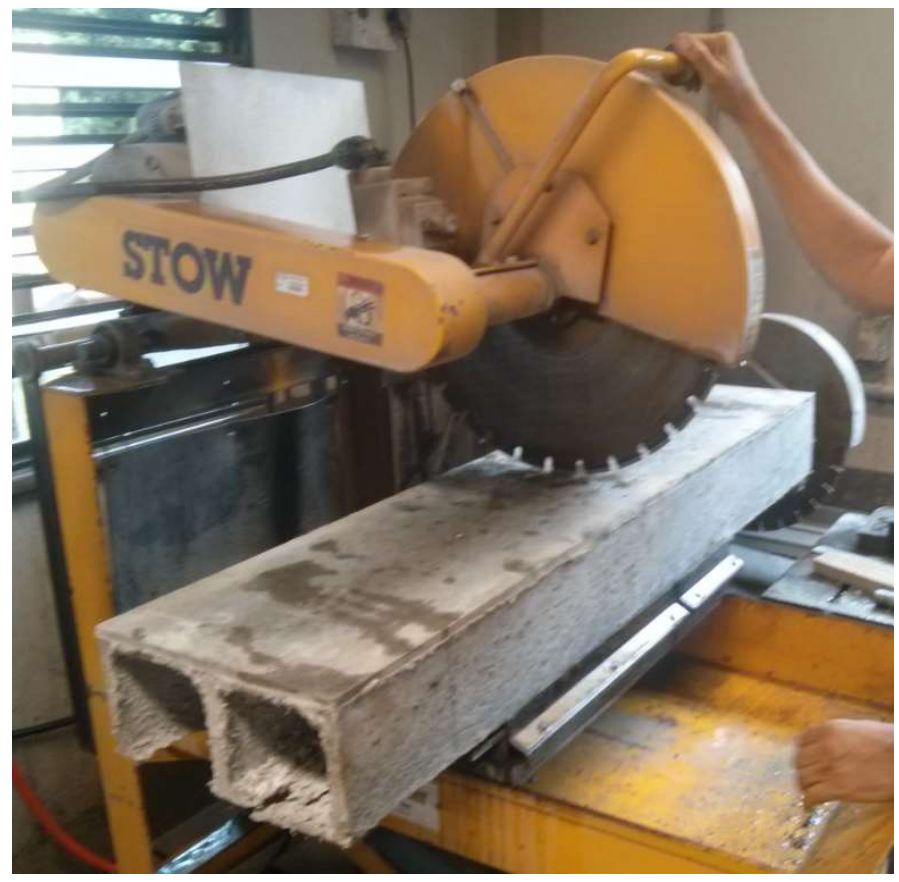

Figura 4.4 - Corte do corpo de prova do painel de $1200 \mathrm{~mm}$ para obtenção de dois modelos de $600 \mathrm{~mm}$ de comprimento (Fonte: Autor)

Para moldagem de todos os corpos de prova dos ensaios de caracterização, foi utilizado um misturador industrial com capacidade de 20 litros. Para a moldagem dos corpos de prova 
do painel alveolar, que exigia um volume muito maior do material, utilizou-se uma betoneira com capacidade de 50 litros. As desmoldagens dos corpos de prova ocorreram em torno de 24 horas após a moldagem. A Figura 4.6 mostra o misturador industrial utilizado na pesquisa.

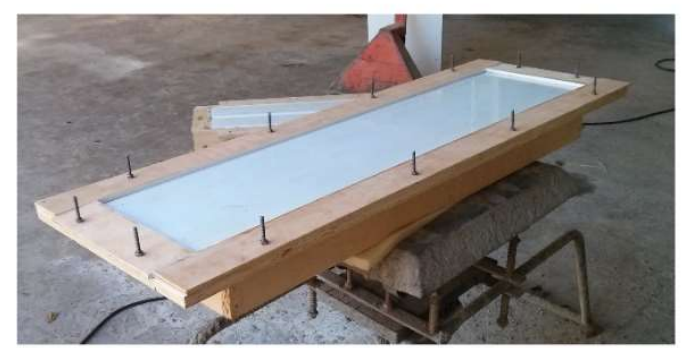

(a)

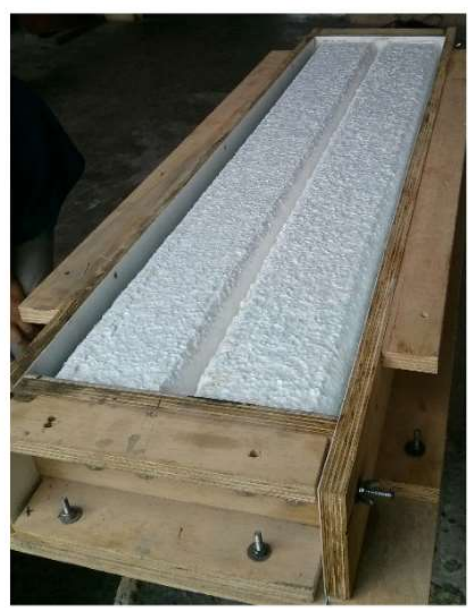

(c)

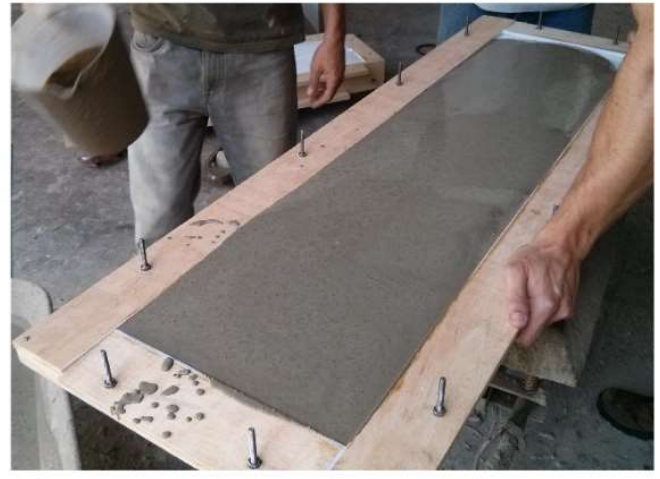

(b)

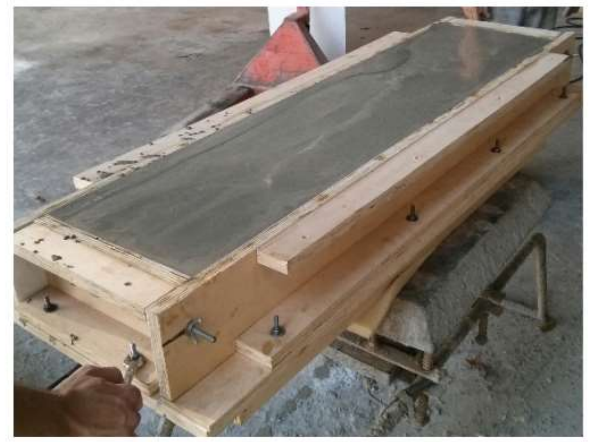

(d)

Figura 4.5 - Etapas de lançamento da argamassa. Fundo (a) e (b) e parte superior (c) e (d) da forma, antes e depois do lançamento. (Fonte: Autor)

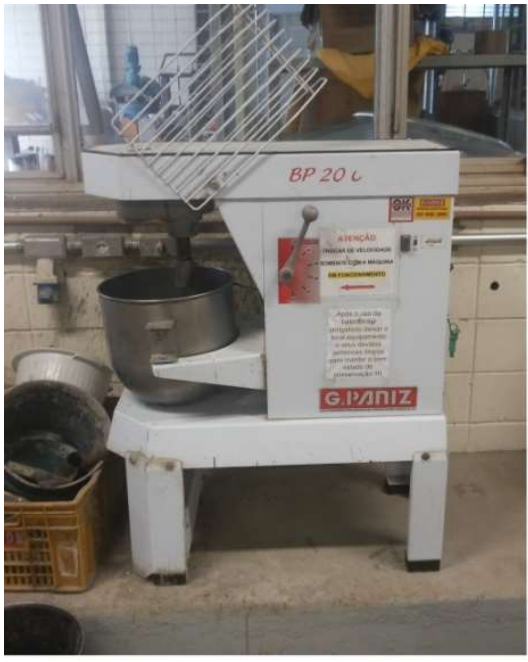

(a)

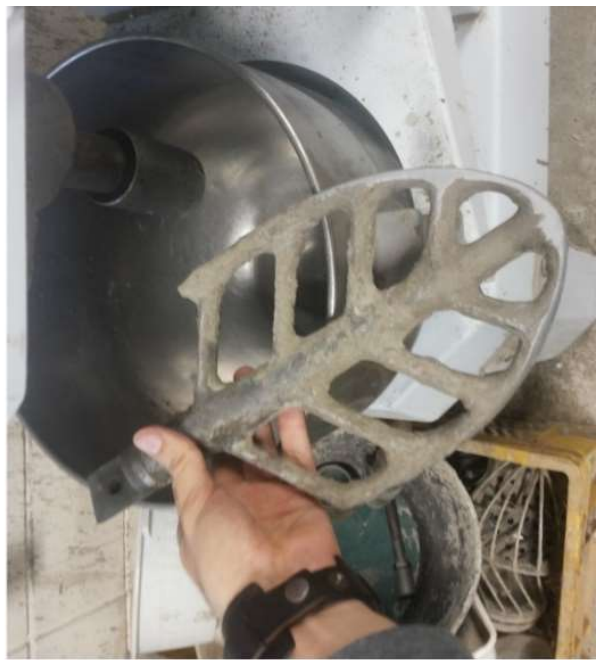

(b)

Figura 4.6 - Misturador industrial utilizado na pesquisa (a) e detalhe da paleta misturadora (b) (Fonte: Autor) 
Após a desmoldagem, os painéis foram curados em câmara úmida até a data de execução dos ensaios. Os ensaios foram realizados com a idade de 7 dias a partir da data de moldagem.

\subsection{Ensaios de caracterização}

Além de ensaios de caracterização do agregado miúdo (areia - item 3.2), em que foram determinadas massa específica, massa unitária e curva granulométrica, também foram realizados ensaios em corpos de prova de argamassa, como descrito na sequência. Para caracterização do material, as argamassas continham teor de fibras de $1 \%$ e $2 \%$, além da argamassa de referência sem a presença das fibras de polipropileno.

\subsection{Ensaio de consistência}

Para a determinação de um parâmetro de consistência para argamassa reforçada com fibras, são seguidas as especificações da norma ABNT NBR 13276:2005, com a utilização de mesa de consistência descrita no anexo B da ABNT NBR 7215:1996.

O ensaio consiste na medida do espalhamento de uma quantidade de argamassa inicialmente moldada em forma de tronco de cone sobre uma mesa de ensaio. A argamassa é lançada em três camadas de mesma altura na forma, aplicando-se respectivamente, 15,10 e 5 golpes uniformes e homogeneamente distribuídos com um soquete normal, na primeira, segunda e terceira camada.

Após o enchimento, retira-se imediatamente a forma e a argamassa moldada se deformará mediante a aplicação de 30 golpes, em aproximadamente 30 segundos, padronizados a uma altura controlada $(12,5 \pm 2 \mathrm{~mm})$. Ao final, são medidos três diâmetros na base do tronco de cone de argamassa. O índice de consistência é a média aritmética das três medidas e arredondada ao número inteiro mais próximo, expresso em milímetros.

A Figura 4.7 apresenta fases do ensaio de consistência segundo a ABNT NBR 13276:2005 e a mesa de consistência da ABNT NBR 7215:1996. 


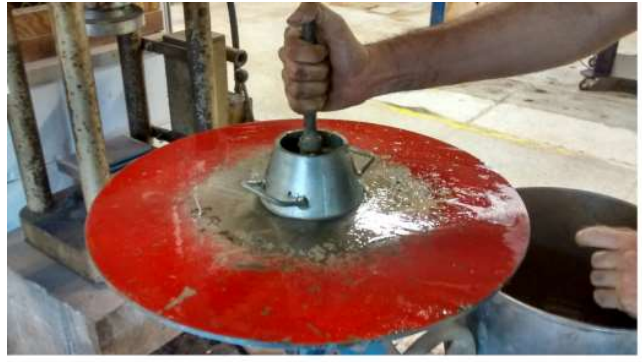

(1)

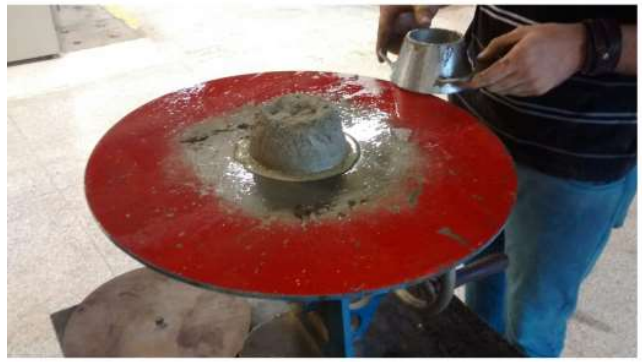

(3)

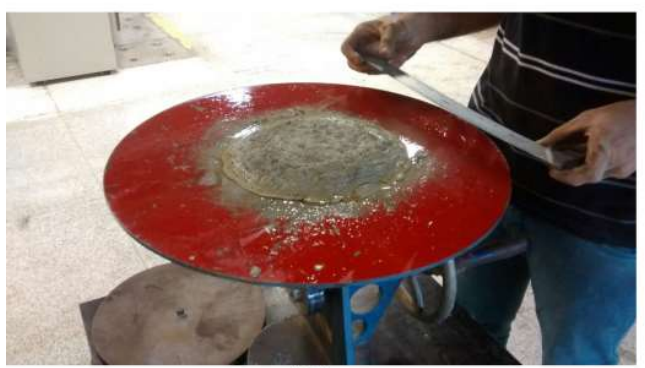

(5)

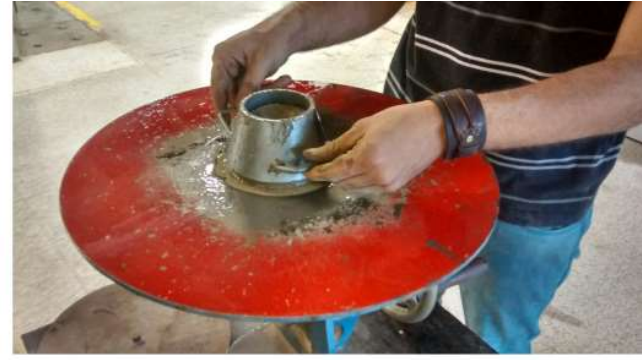

(2)

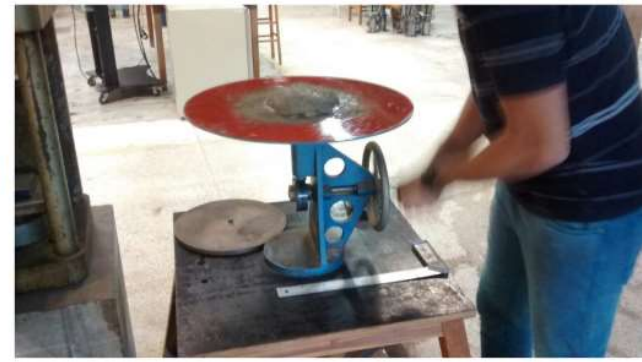

(4)

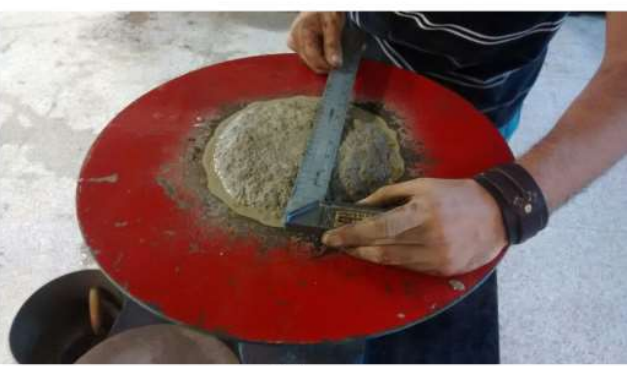

(6)

Figura 4.7 - Fases do ensaio de consistência (Fonte: Autor)

\subsubsection{Ensaio de compressão axial}

Para caracterizar o compósito quanto à sua resistência à compressão, seguiu-se as especificações da norma ABNT NBR 7215:1996. Foram moldados dez corpos de corpos de prova cilíndricos, de $5 \mathrm{~cm}$ de diâmetro e $10 \mathrm{~cm}$ de altura, para cada teor em volume de argamassa $(0,1$ e $2 \%)$.

Além dos corpos de prova de caracterização do material, a cada moldagem do corpo de prova do painel alveolar, eram extraídos seis corpos de prova para a realização deste ensaio, utilizando-se da máquina de ensaio ELE, modelo Autotest 2000.

\subsubsection{Ensaio de módulo de elasticidade}

Para o ensaio de módulo de elasticidade foi utilizado o ensaio acústico para caracterização das amostras de argamassa, segundo os textos normativos ASTM E1876-01 e ASTM C215-02. O esquema do ensaio acústico é mostrado na Figura 4.8. 


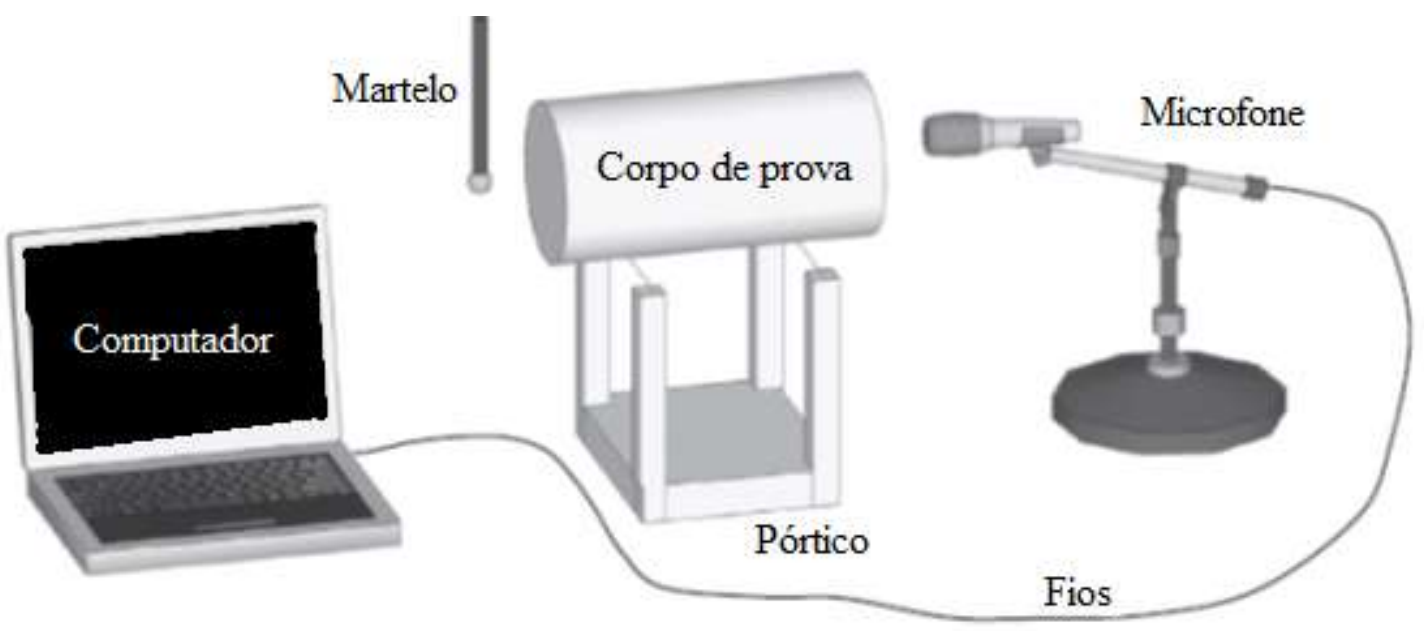

Figura 4.8 - Esquema do ensaio acústico (Haach et al., 2013)

Os materiais e instrumentos para realização do ensaio resumidamente são descritos a seguir:

a) Sistema Sonelastic $\AA$ fornecido pelo fabricante ATCP ENGENHARIA FÍSICA, composto por amplificador, frequencímetro e receptor, que se encontra no Laboratório de Estruturas da Escola de Engenharia de São Carlos LE EESC-USP;

b) Martelo de impacto excitador com cabeça metálica;

c) Balança de precisão;

Por se tratar de um ensaio não destrutivo, as amostras de caracterização para compressão axial foram antes ensaiados por este método de ensaio. As amostras de argamassa foram ensaiadas na idade de 7 dias. A Figura 4.9 apresenta o esquema de ensaio acústico nos corpos de prova de argamassa reforçada com fibras.

O procedimento experimental inicia-se pesando os corpos de prova. Posteriormente, posiciona-se o corpo de prova a ser ensaiado no pórtico, e então se aciona a captura de sinal do microfone e excita-se o corpo de prova. Por meio de correlações o programa informa o módulo de elasticidade dinâmico da amostra.

\subsubsection{Ensaio de tração por compressão diametral}

Para caracterização quanto à resistência à tração por compressão diametral, seguiu-se os procedimentos regidos pela ABNT NBR 7222:1994. Utiliza-se para este ensaio, um corpo de prova cilíndrico com dimensões de $50 \mathrm{~mm}$ de diâmetro por $100 \mathrm{~mm}$ de altura. Submetendo 
o corpo de prova à ação de forças de compressão linearmente distribuídas e diametralmente opostas, surgem tensões de tração perpendiculares ao plano da ação de força de compressão.

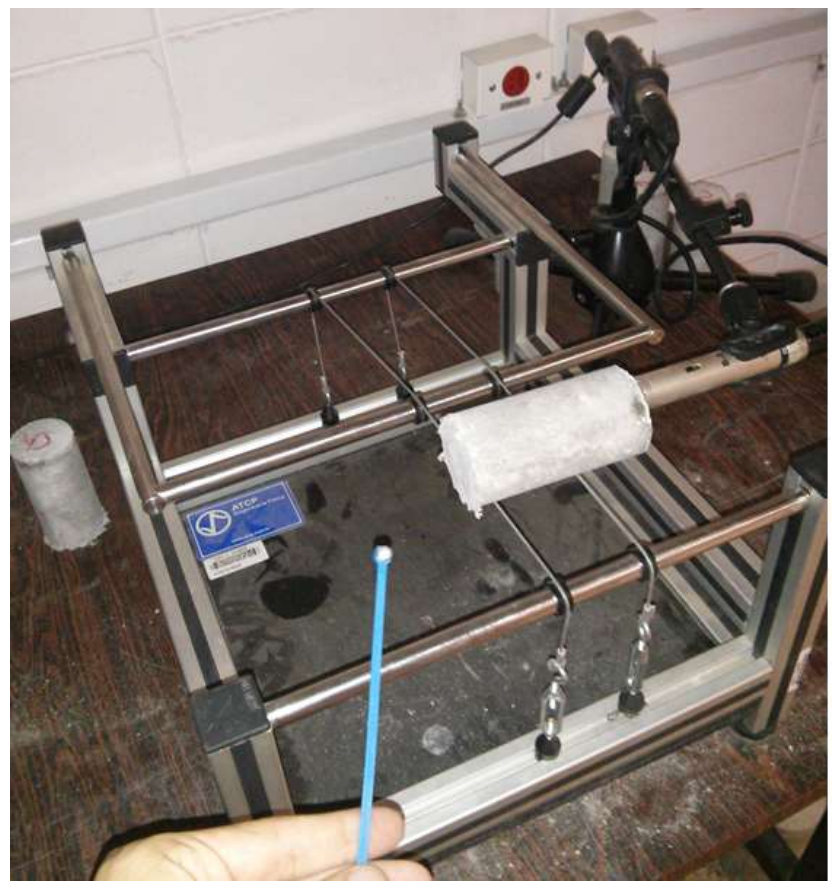

Figura 4.9 - Ensaio acústico em corpo de prova de argamassa reforçada com fibras de polipropileno (Fonte: Autor)

Para se estimar a resistência à tração deve-se aplicar a Equação 02.

$$
f_{t}=0,85 \frac{2 \cdot F}{\pi \cdot d \cdot h} \text { Eq. (02) }
$$

Onde:

$f_{t}=$ Resistência à tração por compressão diametral;

$F=$ Força máxima obtida no ensaio;

$d=$ diâmetro do corpo de prova;

$h=$ altura do corpo de prova.

Ensaiaram-se dez corpos de prova para cada teor de fibras em volume de argamassa $(0,1$ e $2 \%)$ para caracterização do material. A cada moldagem do corpo de prova do painel, extraia-se seis corpos de prova para realização desse ensaio.

Os ensaios foram realizados na máquina de ensaio ELE, modelo Autotest 2000. 


\subsubsection{Ensaio de tração na flexão}

Para caracterização quanto à resistência à tração por flexão foram seguidos os procedimentos regidos pela ABNT NBR 13279:2005. O ensaio em argamassas é realizado com corpo de prova prismático de dimensões $4 \mathrm{~cm}$ x $4 \mathrm{~cm}$ x $16 \mathrm{~cm}$. Os corpos de prova foram desmoldados após de 24 horas, e curados em câmara úmida por sete dias, que correspondia a data de realização do ensaio.

Os ensaios de tração na flexão foram realizados na máquina de ensaios INSTRON, modelo 8506.

O ensaio consiste na aplicação de uma carga centrada, com velocidade de carregamento de $50 \mathrm{~N} / \mathrm{s}$, em um corpo de prova bi-apoiado até a sua ruptura. A resistência à tração na flexão é calculada segundo a Equação (3). A Figura 4.10 mostra detalhadamente as dimensões dos dispositivos assim como suas posições e a Figura 4.11, as etapas do ensaio e comparação dos corpos de prova após o fim do ensaio.

$$
\begin{gathered}
f_{t, f}=\frac{1,5 \cdot F \cdot L}{40^{3}} \quad \text { Eq. (03) } \\
\text { Sendo } \mathrm{L}=100 \mathrm{~mm}, f_{t, f}=\frac{150 \cdot F}{40^{3}}
\end{gathered}
$$

Onde:

$f_{t, f}=$ Resistência à tração na flexão $(\mathrm{MPa})$;

$F=$ Carga aplicada verticalmente no centro do prisma $(\mathrm{N})$;

$L=$ distância entre apoios (mm); 


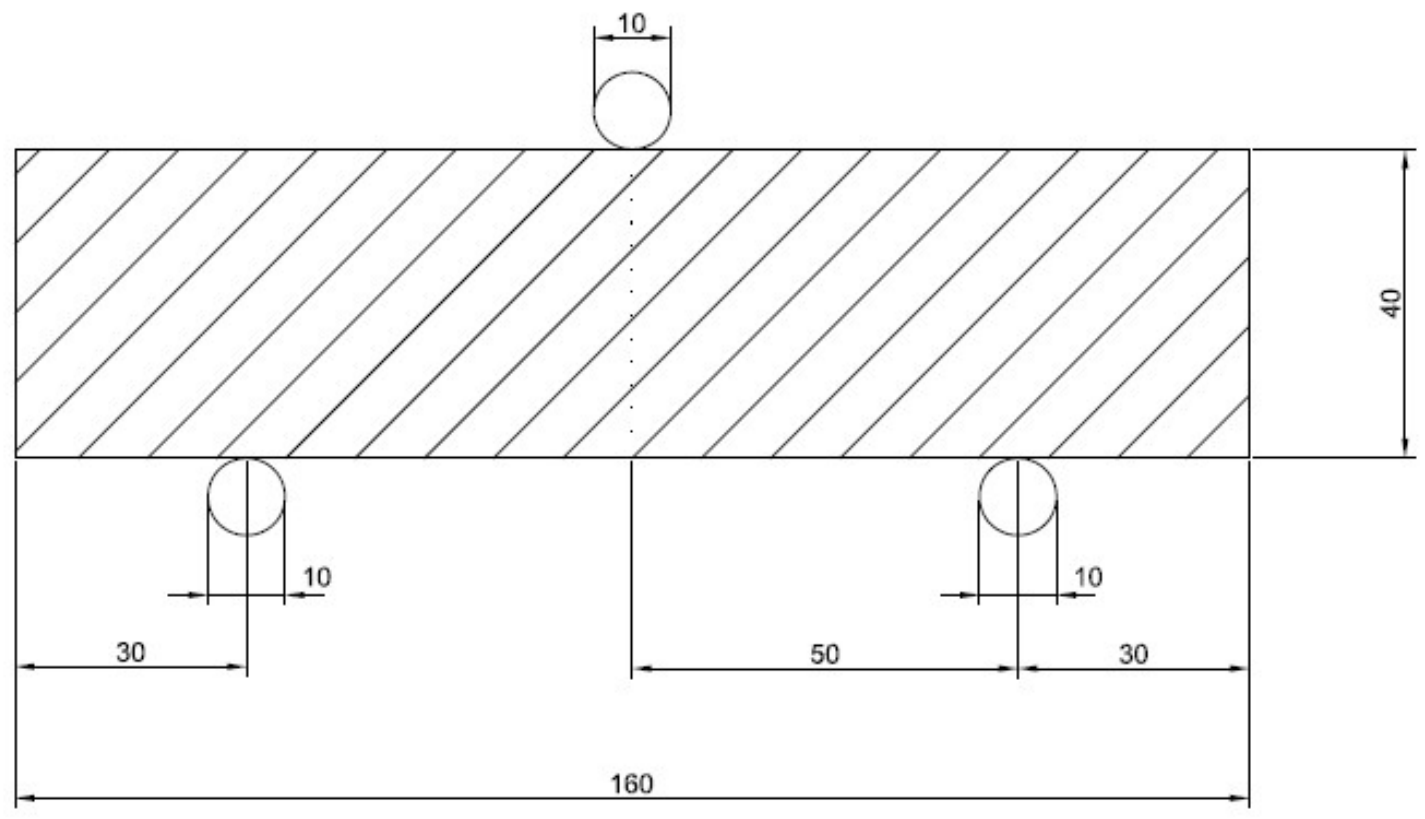

Figura 4.10 - Esquema de ensaio para determinação da resistência à tração na flexão - medidas em mm (Fonte: Autor)

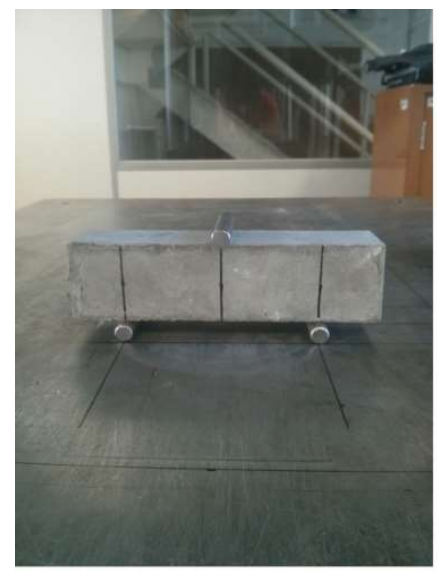

(a)

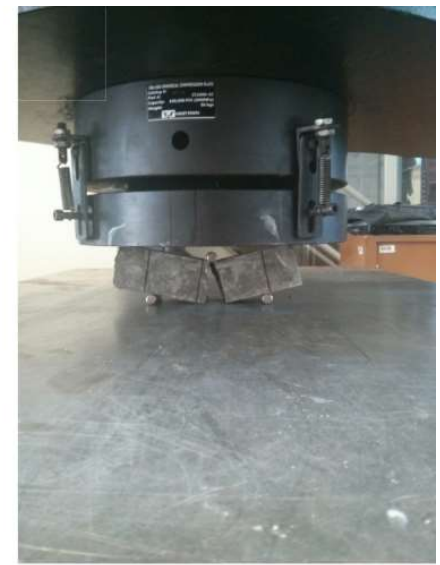

(b)

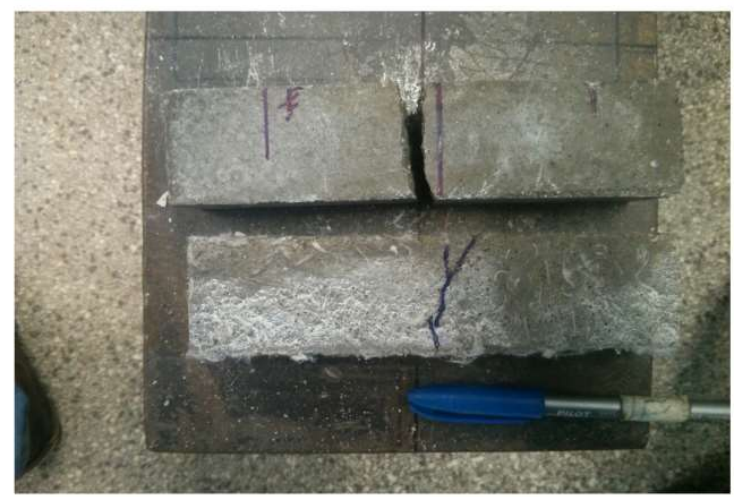

(c)

Figura 4.11 - Prepaparação do corpo de prova para o ensaio (a), ruptura do corpo de prova e fim do ensaio (b) e comparação dos corpos de prova sem fibras e com fibras após a finalização do ensaio (c) (Fonte: Autor) 


\subsubsection{Ensaio de tenacidade à fratura}

O ensaio de tenacidade foi adaptado seguindo os procedimentos regidos pela norma ASTM C1609. O modelo de corpo de prova assim como o processo de cura para o ensaio de tenacidade são os mesmos do ensaio de tração na flexão descrito anteriormente, com a única diferença que os corpos de prova para este ensaio foram entalhados com uma profundidade de $4 \mathrm{~mm}$ no trecho central. Adotou-se $4 \mathrm{~mm}$ para entalhe devido às pequenas dimensões do corpo de prova, valores exatamente proporcionais à norma de referência apresentavam fissurações no modelo.

O ensaio é realizado com controle de deslocamento através da utilização de transdutor de deslocamento (clip gauge) posicionado no entalhe com precisão de $0,001 \mathrm{~mm} / \mathrm{s}$, conforme apresentado na Figura 4.12. A taxa de deslocamento (abertura da fissura) aumenta a uma velocidade constante de $0,05 \mathrm{~mm} / \mathrm{min}$. Quando o valor da abertura de fissura alcança $0,1 \mathrm{~mm}$, a taxa de deslocamento é aumentada para o valor de $0,2 \mathrm{~mm} / \mathrm{min}$. A abertura de fissura deve ser superior a $4 \mathrm{~mm}$ para que o ensaio seja finalizado. Além do clip gauge, são posicionados dois transdutores de deslocamento com precisão de $0,01 \mathrm{~mm}$, para medir o deslocamento vertical, posicionados em lados opostos e apoiados na máquina de ensaio. O sistema de aquisição registra os valores obtidos para posterior construção do gráfico força - abertura de fissura, assim como o gráfico força - deslocamento, que serão importantes para se mensurar a capacidade de absorção de energia das amostras.

A Figura 4.13 apresenta a configuração do ensaio com o corpo de prova durante (a) e após (b) o ensaio, e a Figura 4.14 mostra a face dos corpos de prova no plano de ruptura para os teores 0,1 e $2 \%$ de fibras de polipropileno.

Os ensaios de tenacidade foram realizados na máquina de ensaios INSTRON, modelo 8506. 

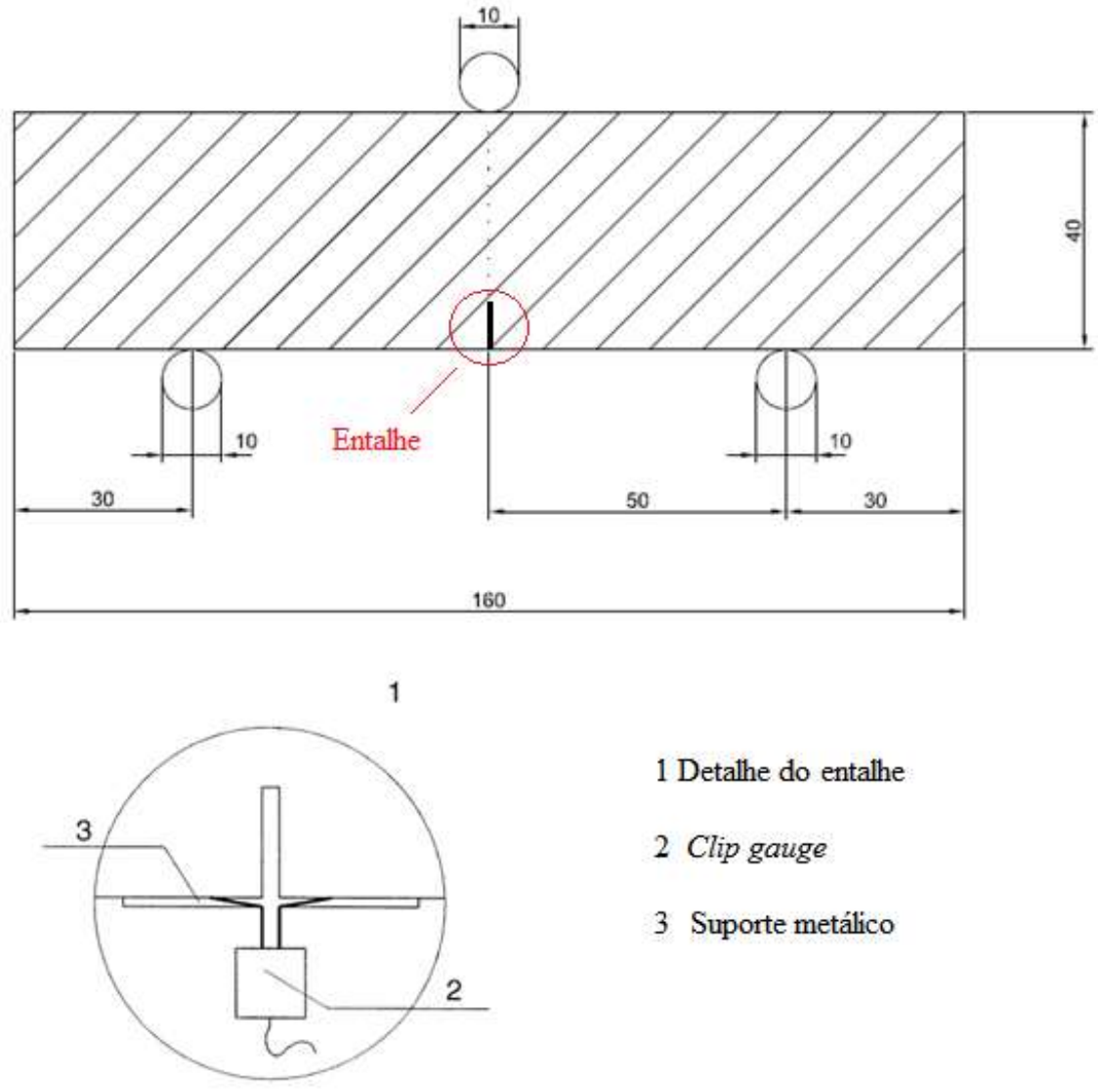

1 Detalhe do entalhe

2 Clip gauge

3 Suporte metálico

Figura 4.12 - Esquema de ensaio para determinação da resistência de tenacidade e detalhe no entalhe - medidas em mm (Fonte: Autor)

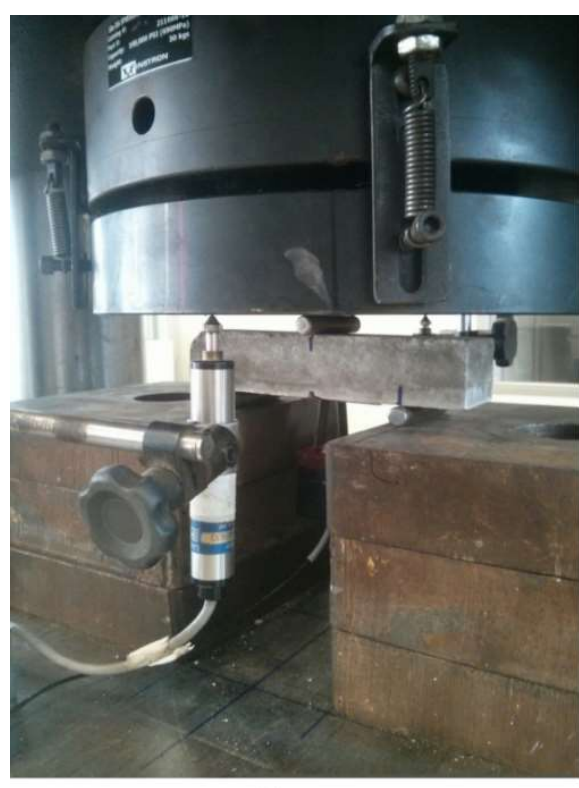

(a)

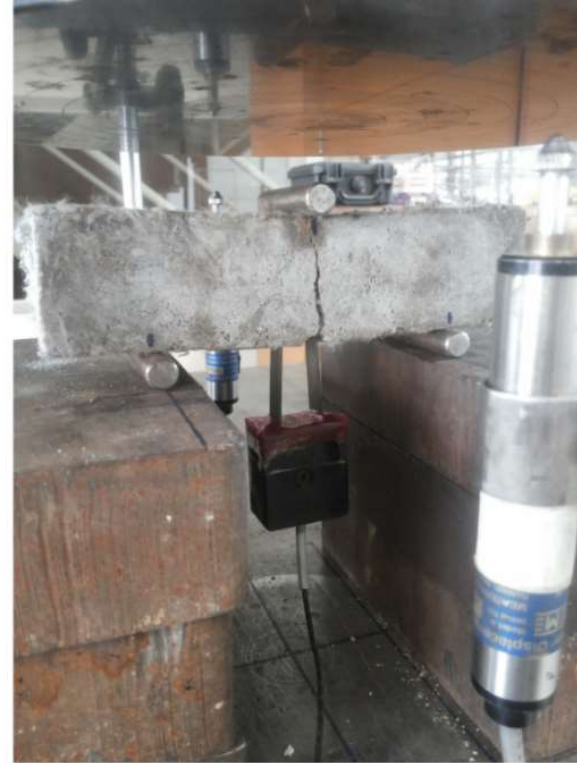

(b)

Figura 4.13 - Detalhe do corpo de prova durante o ensaio (a) e pós ensaio (b) (Fonte: Autor) 


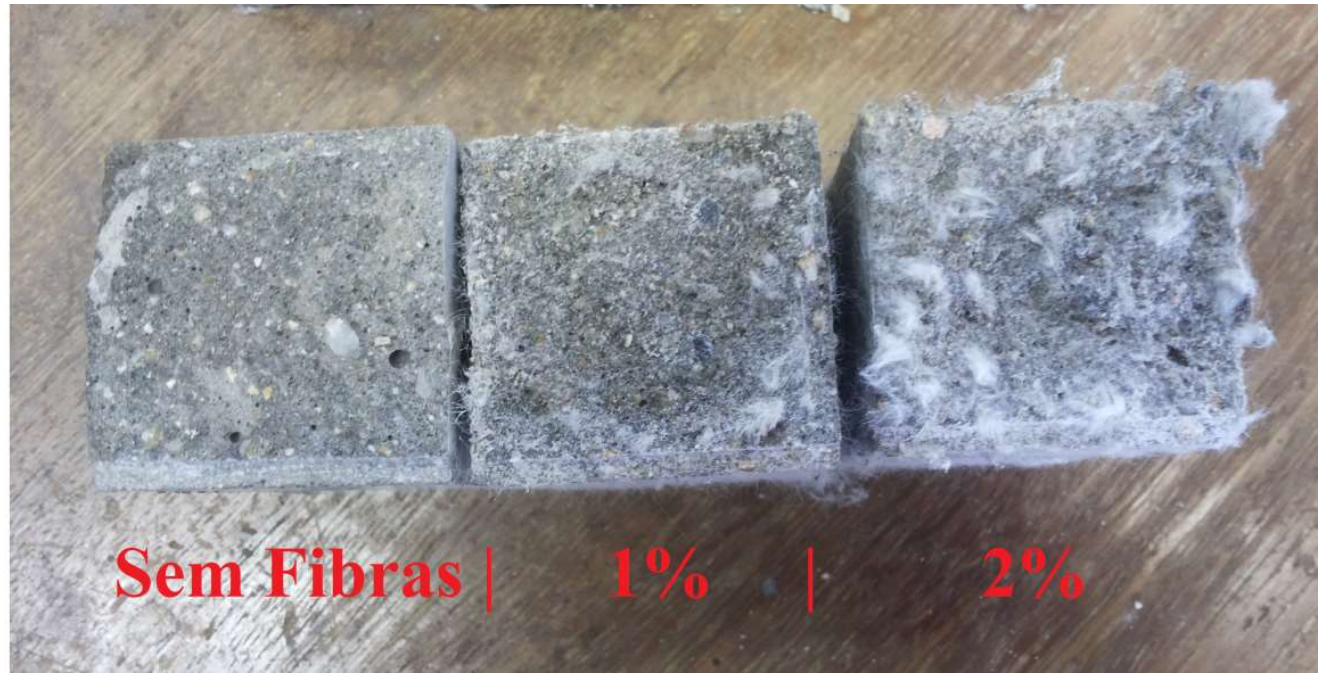

Figura 4.14 - Face do plano de ruptura dos corpos de prova para os diferentes teores de fibras utilizados na pesquisa (Fonte: Autor)

\subsection{Ensaios nos painéis alveolares}

Os ensaios descritos a seguir, nos modelos de corpo de prova dos painéis alveolares, desenvolveram-se na máquina de ensaios da marca INSTRON, modelo 8506.

\subsubsection{Ensaio de carga concentrada}

Nesta pesquisa optou-se por realizar o ensaio de carga concentrada com o objetivo de comparar a influência da inclusão de alto teor de fibras de polipropileno na capacidade de resistir a carregamentos pontuais aplicadas no painel alveolar.

O ensaio apresentado a seguir seria uma adaptação seguindo os preceitos da ABNT NBR 11675:2016, porém não se representa ensaio de impacto por corpo duro e corpo mole. O ensaio, portanto, assemelha-se mais a um ensaio de resistência à punção da face do painel.

O corpo de prova do painel para este ensaio é apresentado na Figura 4.3.a. Foram ensaiados quatro corpos de prova para argamassa reforçada com $2 \%$ de fibras e quatro para a argamassa de referência.

A face inferior do painel foi apoiada e sobre a face superior foram aplicadas independentemente as cargas, com controle de deslocamento da máquina a uma taxa de $0,01 \mathrm{~mm} / \mathrm{s}$, em cada um dos pontos da Figura 4.15.

Para simular a aplicação de uma carga em um ponto, utilizou-se uma esfera metálica, posicionada sobre o ponto desejado, apoiada no topo por uma chapa metálica. A Figura 4.16 apresenta essa configuração de ensaio e a Figura 4.17 o furo oriundo do ensaio apresentando o detalhe da esfera e da chapa metálica. 


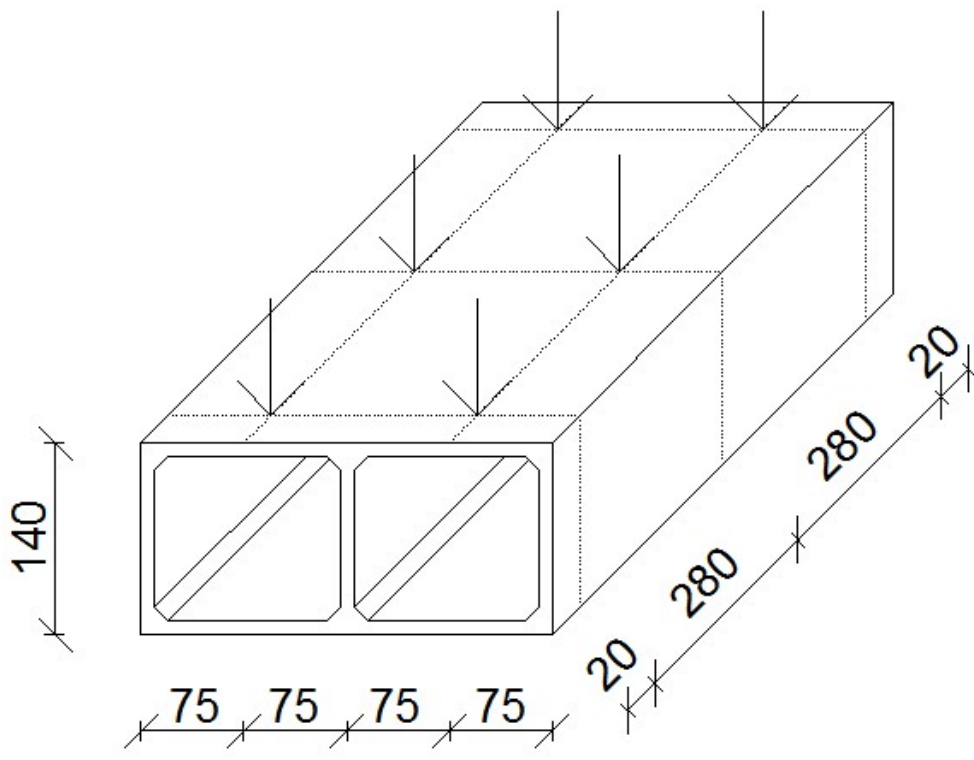

\section{Pontos de aplicação da carga concentrada}

Figura 4.15 - Localização dos pontos de aplicação da carga para o ensaio de carga concentrada (carga aplicada isoladamente em cada um dos pontos) (Fonte: Autor)

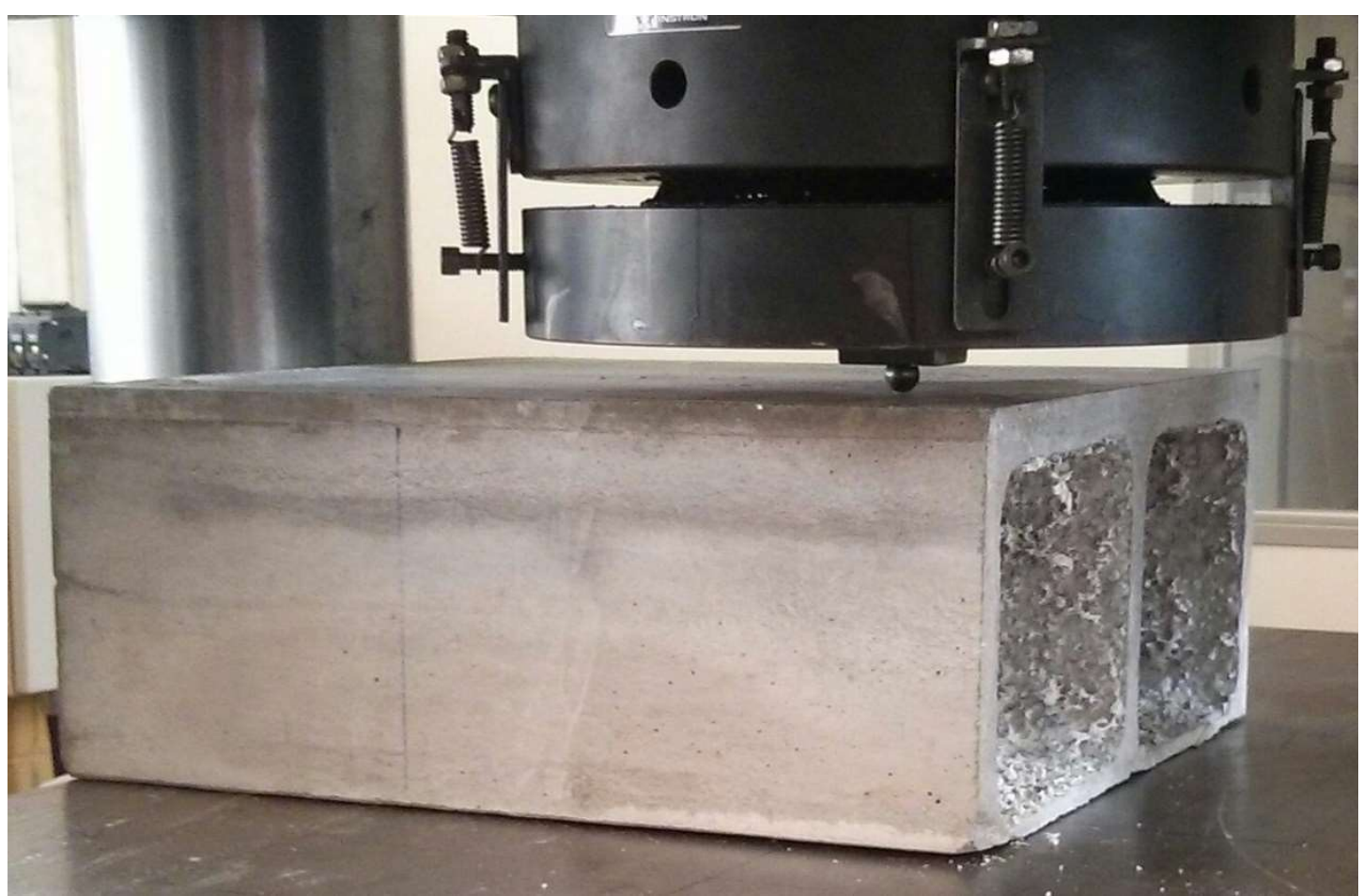

Figura 4.16 - Preparação do corpo de prova para o ensaio de carga concentrada (Fonte: Autor) 


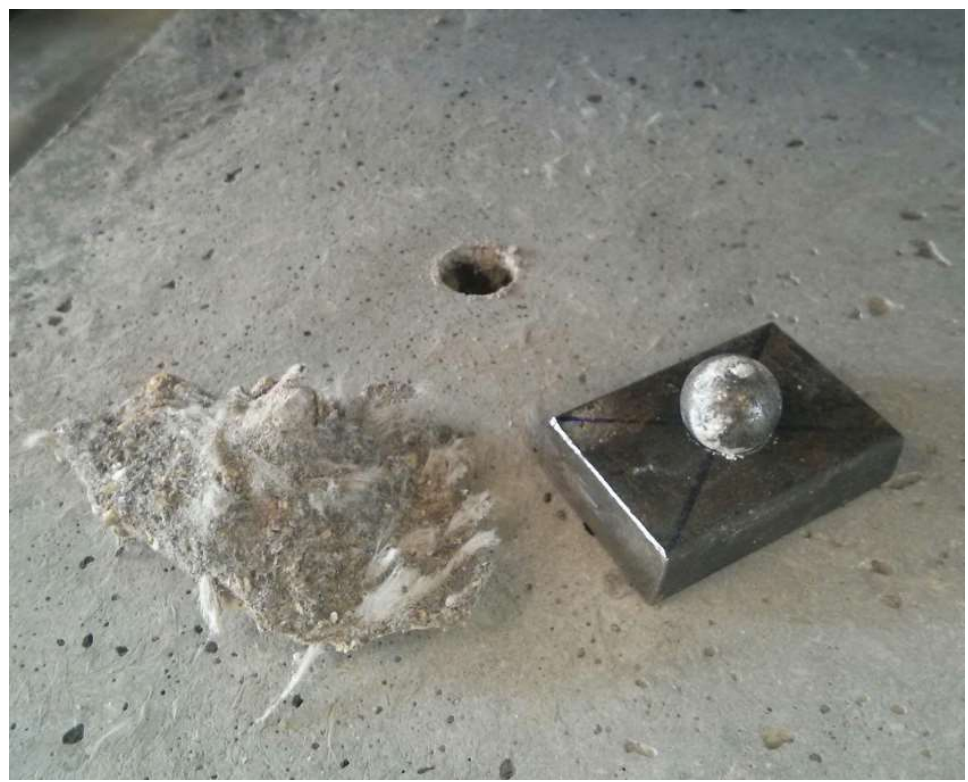

Figura 4.17 - Furo após a finalização do ensaio e cone extraído do corpo de prova da região do ensaio (Fonte: Autor)

\subsubsection{Ensaio de resistência à flexão}

Este ensaio foi realizado para verificar a influência das fibras de polipropileno no comportamento quanto à flexão nos painéis alveolares.

Foram moldados dois corpos de prova para a argamassa com $2 \%$ fibras e dois para argamassa de referência, com dimensões de 300 mm x 140 mm e 1200 mm de comprimento, conforme mostrado na Figura 4.3.b.

Devido à geometria dos corpos de prova, o ensaio foi adaptado seguindo as prescrições da ABNT NBR 12142:1991. Foram utilizados seis transdutores de deslocamentos com precisão de $0,01 \mathrm{~mm}$ nos ensaios, além de um LVDT com precisão de 0,0005 mm. A Figura 4.18 apresenta o esquema do ensaio e a posição dos transdutores de deslocamento que serão adotados e a Figura 4.19 a preparação do corpo de prova para o ensaio de flexão. 


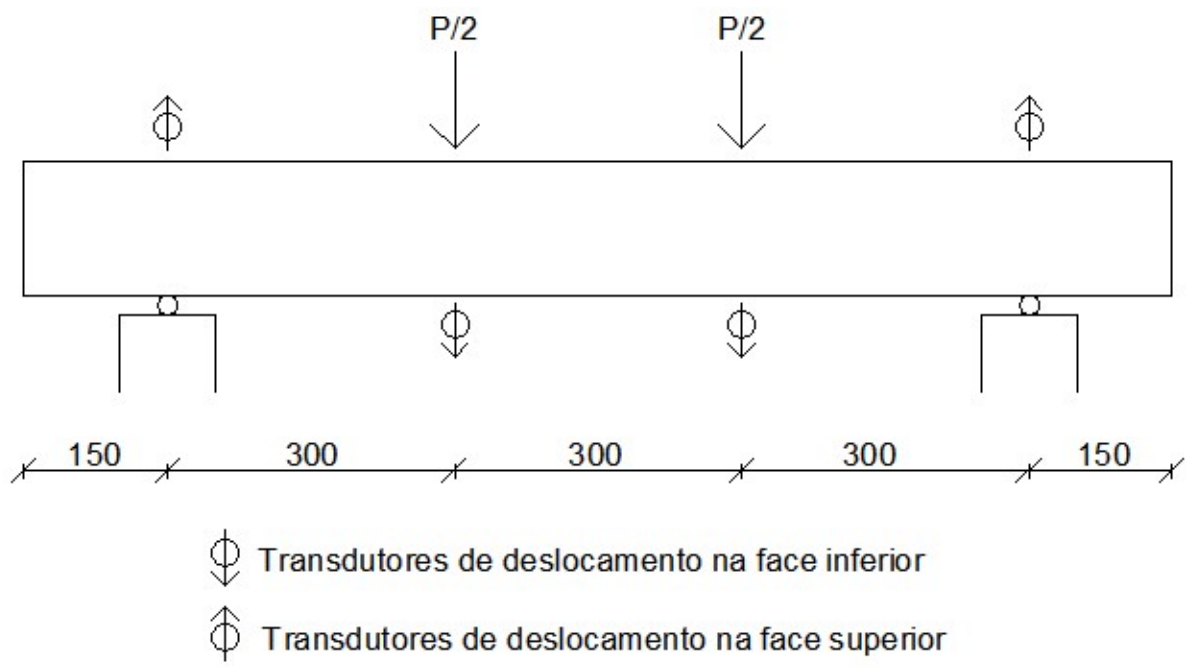

(a)
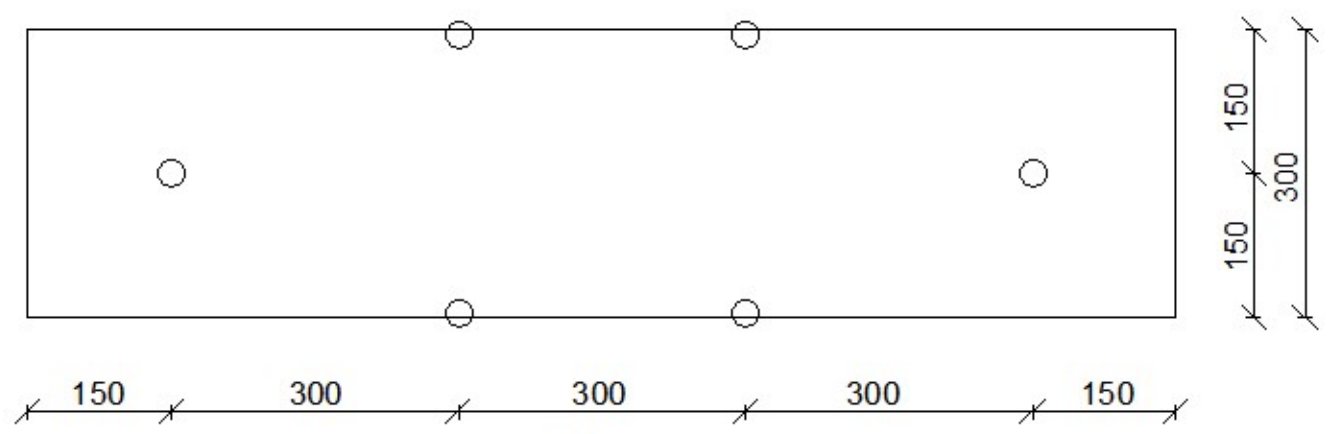

(b)

Figura 4.18 - Localização dos transdutores de deslocamento em corte (a) e em planta (b) do corpo de prova do painel para o ensaio de flexão (Fonte: Autor)

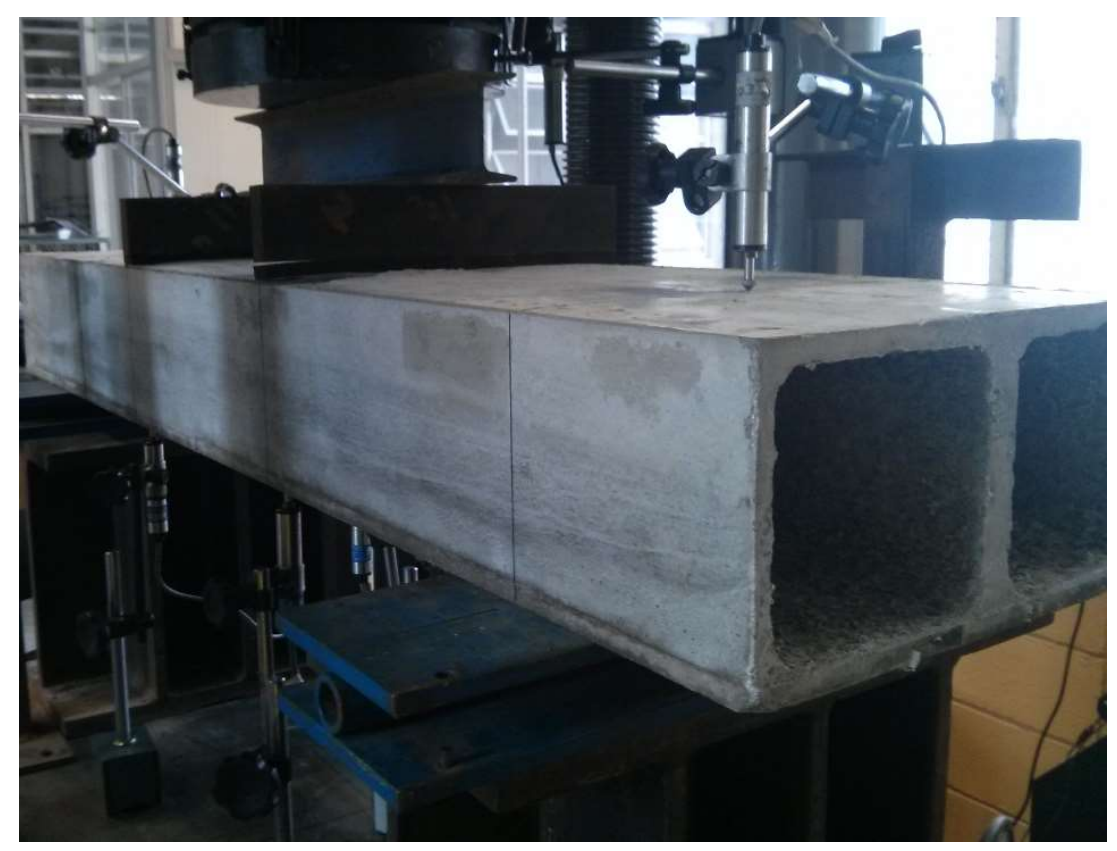

Figura 4.19 - Preparação do corpo de prova para o ensaio de flexão (Fonte: Autor) 
A Figura 4.20, apresenta a diferença de ruptura dos corpos de prova com $2 \%$ de fibra e sem fibras utilizados no ensaio.

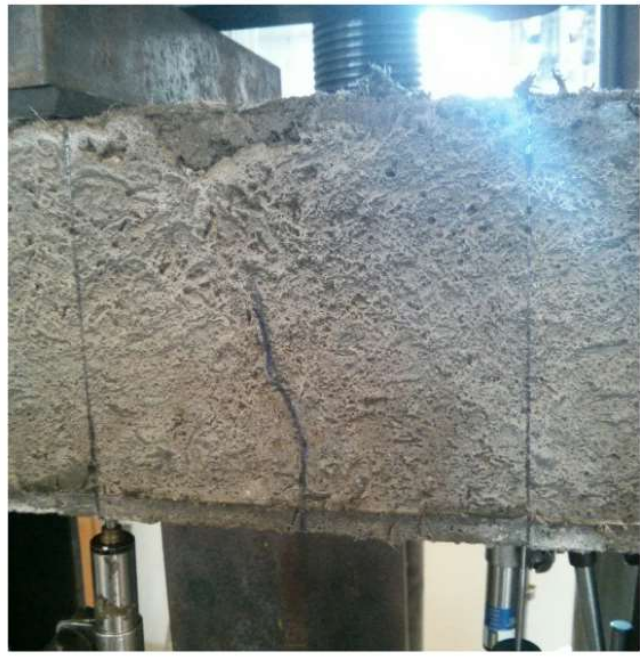

(a)

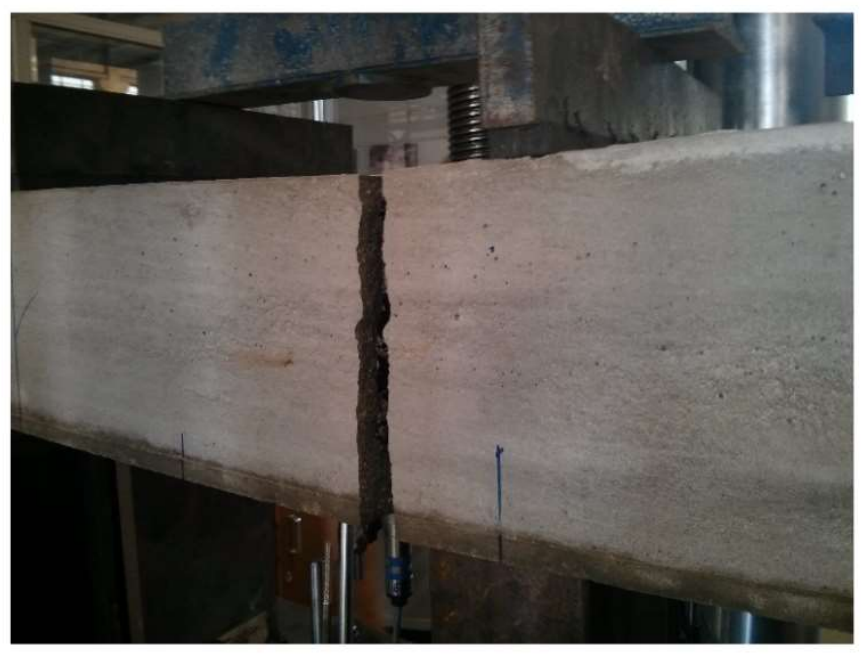

(b)

Figura 4.20 - Detalhe dos corpos de prova com 2\% de fibras (a) e sem fibras (b) rompidos após o ensaio (Fonte: Autor) 


\section{ANÁLISE DE RESULTADOS}

Neste capítulo são apresentados e discutidos os resultados dos ensaios de caracterização do material, que compõem:

- Consistência;

- Compressão axial;

- Módulo de elasticidade;

- Tração por compressão diametral;

- Tração na flexão;

- Tenacidade.

Além dos ensaios realizados nos corpos de prova dos painéis alveolares, sendo eles o ensaio de flexão e carga concentrada.

\subsection{Ensaio de caracterização das propriedades da argamassa modificada}

\subsubsection{Ensaio de consistência}

Apresenta-se, na Tabela 5.1, os resultados dos ensaios de consistência, observando a grande influência do teor de fibras na consistência da mistura. Para cada teor de fibra de polipropileno, os valores apresentados representam a média de três medidas.

Observa-se que o índice de consistência decai significativamente de amostras sem fibras para amostras com $1 \%$ de fibras, e ocorre uma redução ainda maior para amostras com $2 \%$ de fibras. A diminuição do valor do índice de consistência representa um aumento da consistência da mistura e indica uma menor trabalhabilidade.

Tabela 5.1 - Resultados dos ensaios de consistência (Fonte: Autor)

\begin{tabular}{cc}
\hline Teor de fibras (\%) & $\begin{array}{c}\text { Índice de consistência } \\
\text { médio }(\mathbf{c m})\end{array}$ \\
\hline 0 & 34,14 \\
1 & 21,12 \\
2 & 17,62 \\
\hline
\end{tabular}




\subsubsection{Ensaio de compressão axial}

O resultado do ensaio de resistência à compressão, pela análise de médias, indica que o aumento do teor de fibras na mistura não influencia na resistência à compressão. $\mathrm{O}$ gráfico da Figura 5.1 e a Tabela 5.2 apresentam os resultados do ensaio.

Tabela 5.2 - Resultados dos ensaios de compressão axial (Fonte: Autor)

\begin{tabular}{ccccc}
\hline $\begin{array}{c}\text { Teor de fibras } \\
(\%)\end{array}$ & $\begin{array}{c}\text { Quantidade de } \\
\text { amostras }\end{array}$ & $\begin{array}{c}\text { Resistência à } \\
\text { compressão } \\
\text { média - 7 dias } \\
\text { (MPa) }\end{array}$ & $\begin{array}{c}\text { Desvio padrão } \\
\text { (MPa) }\end{array}$ & $\begin{array}{c}\text { Coeficiente de } \\
\text { variação (\%) }\end{array}$ \\
\hline 0 & \multicolumn{5}{c}{39,62} & 1,81 & 4,56 \\
1 & 10 & 39,61 & 3,07 & 7,75 \\
2 & 10 & 37,17 & 1,70 & 4,58 \\
\hline
\end{tabular}

Os resultados para todos os corpos de prova são mostrados no Anexo A.

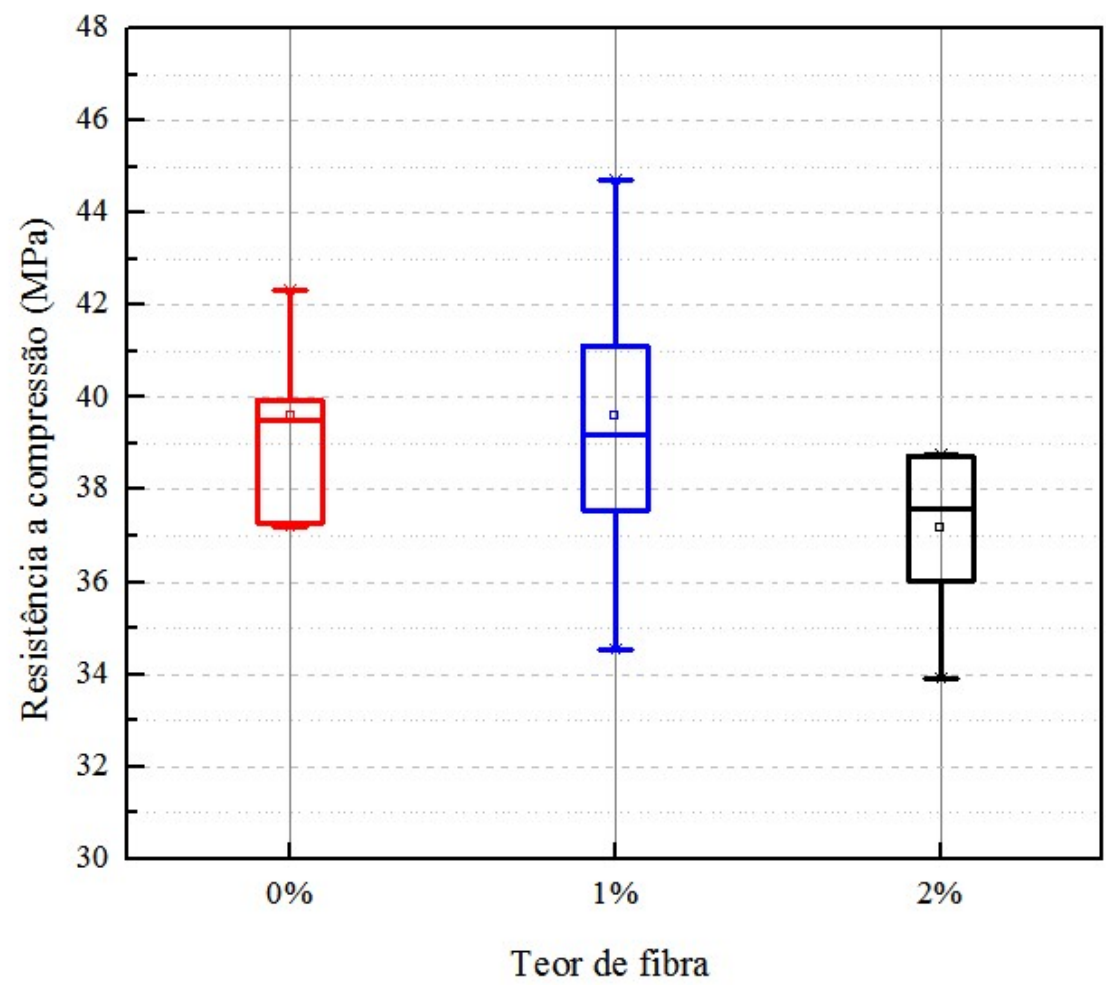

Figura 5.1 - Resultados do ensaio de compressão axial (Fonte: Autor) 


\subsubsection{Ensaio de módulo de elasticidade}

Para o ensaio de módulo de elasticidade, os resultados são mostrados no gráfico da Figura 5.2 e na Tabela 5.3.

Obtiveram-se médias para 0,1 e 2\% de fibras de polipropileno, respectivamente, 27,26 $\mathrm{GPa}, 28,89 \mathrm{GPa}$ e $31,09 \mathrm{GPa}$. A diferença de valores de 0 para $1 \%$ de fibras de polipropileno foi de $5,64 \%$, e de 0 para $2 \%$ de $12,31 \%$.

Os resultados indicam um pequeno aumento sobre o módulo de elasticidade para o teor de $1 \%$ de fibras, e um leve ganho para $2 \%$ de fibras, quando comparados aos resultados obtidos para as argamassas de referência.

Tabela 5.3 - Resultados dos ensaios de módulo de elasticidade

\begin{tabular}{ccccc}
\hline $\begin{array}{c}\text { Teor de fibras } \\
(\%)\end{array}$ & $\begin{array}{c}\text { Quantidade de } \\
\text { amostras }\end{array}$ & $\begin{array}{c}\text { Módulo de } \\
\text { elasticidade }-7 \\
\text { dias (GPa) }\end{array}$ & $\begin{array}{c}\text { Desvio padrão } \\
\text { (GPa) }\end{array}$ & $\begin{array}{c}\text { Coeficiente de } \\
\text { variação (\%) }\end{array}$ \\
\hline 0 & 20 & 27,26 & 1,94 & 7,13 \\
1 & 20 & 28,63 & 1,15 & 5,50 \\
2 & 20 & 31,09 & 2,27 & 7,31 \\
\hline
\end{tabular}

Os resultados para todos os corpos de prova são mostrados no Anexo A.

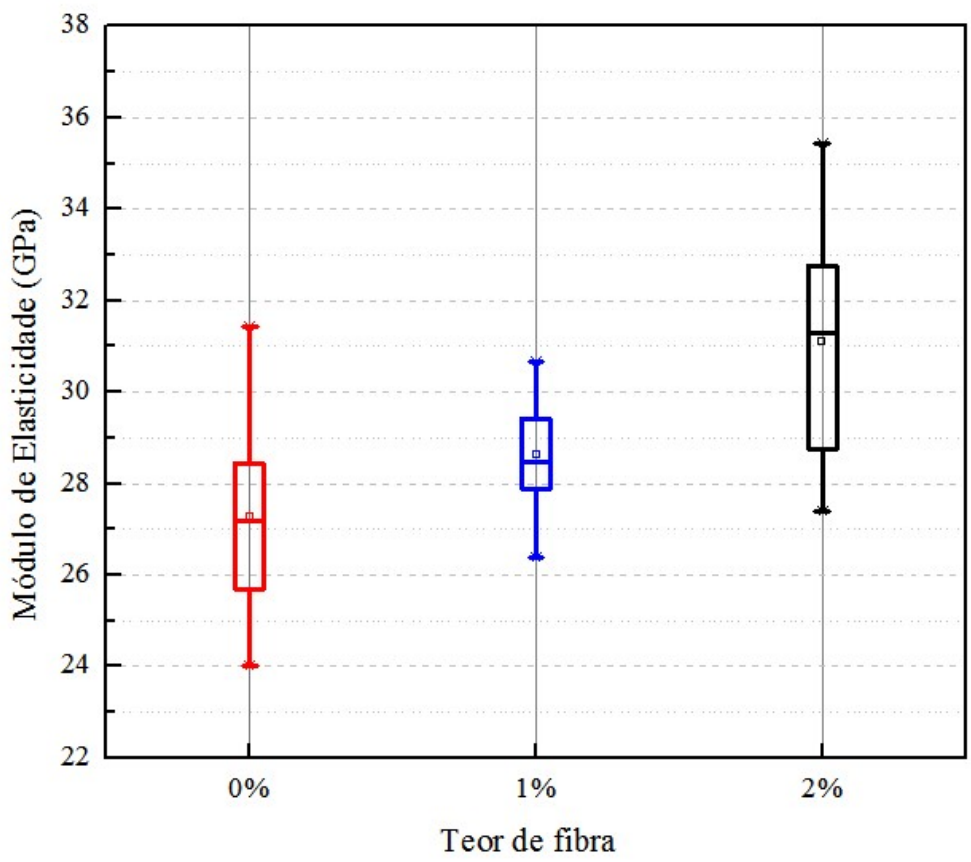

Figura 5.2 - Resultados do ensaio de módulo de elasticidade 


\subsubsection{Ensaio de tração por compressão diametral}

Para o ensaio de tração por compressão diametral, os resultados são mostrados na Figura 5.3 e na Tabela 5.4 .

Obtiveram-se médias para 0,1 e $2 \%$ de fibras de polipropileno, respectivamente, 2,52 $\mathrm{MPa}, 3,01 \mathrm{MPa}$ e 3,43 MPa. A diferença de valores de 0 para 1\% fibras de polipropileno foram de $16,28 \%$, de 1 para $2 \%$ de $12,24 \%$, e de 0 para $2 \%$ de $26,53 \%$.

Estes resultados indicam um efeito significativo na resistência à tração por este ensaio pela utilização de teores de fibras elevados, observando-se um aumento da resistência à tração por compressão diametral com o aumento do teor de fibra.

Tabela 5.4 - Resultados dos ensaios de tração por compressão diametral (Fonte: Autor)

\begin{tabular}{|c|c|c|c|c|}
\hline $\begin{array}{c}\text { Teor de fibras } \\
\text { (\%) }\end{array}$ & $\begin{array}{c}\text { Quantidade de } \\
\text { amostras }\end{array}$ & $\begin{array}{c}\text { Resistência à } \\
\text { tração por } \\
\text { compressão } \\
\text { diametral média } \\
\text { - } 7 \text { dias (MPa) }\end{array}$ & $\begin{array}{c}\text { Desvio padrão } \\
\text { (MPa) }\end{array}$ & $\begin{array}{l}\text { Coeficiente de } \\
\text { variação (\%) }\end{array}$ \\
\hline 0 & 10 & 2,52 & 0,35 & 13,75 \\
\hline 1 & 10 & 3,01 & 0,32 & 10,55 \\
\hline 2 & 10 & 3,55 & 0,16 & 4,50 \\
\hline
\end{tabular}

Os resultados para todos os corpos de prova são mostrados no Anexo A.

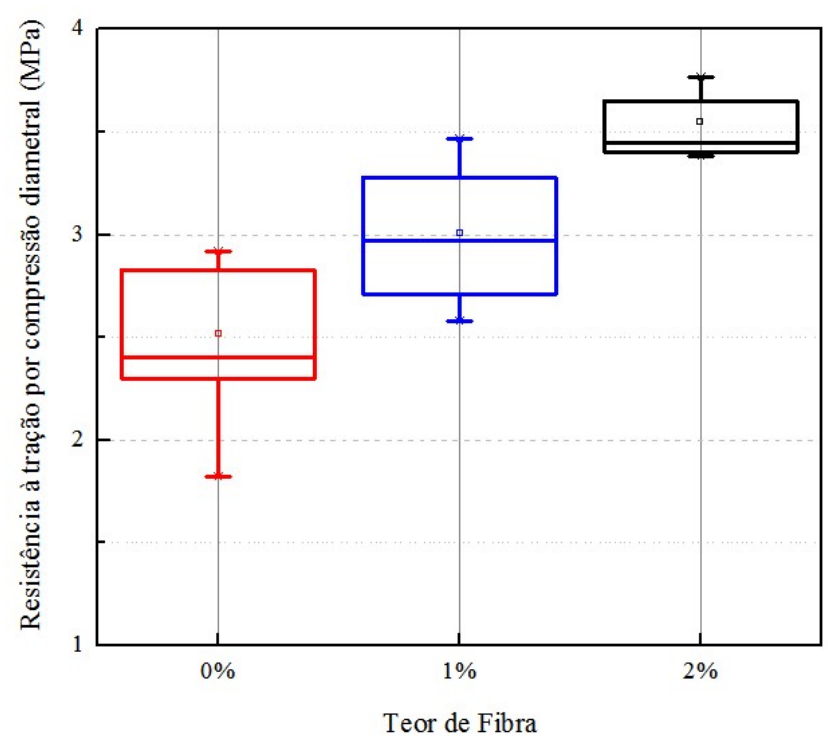

Figura 5.3 - Resultados do ensaio de tração por compressão diametral (Fonte: Autor) 


\subsubsection{Ensaio de tração na flexão}

Para o ensaio de tração na flexão, os resultados são mostrados na Figura 5.4 e na Tabela 5.5 .

A diferença de valores de 0 para $1 \%$ de fibras de polipropileno foram de $8,88 \%$, de 1 para $2 \%$ de $3,19 \%$, de 0 para $2 \%$ de $11,79 \%$. Estes resultados indicam um efeito pouco significativo, na resistência à tração por flexão, da utilização de teores de fibras elevados. Isso pode representar problemas de sensibilidade das células de carga de equipamentos diferentes.

Tabela 5.5 - Resultados dos ensaios de tração na flexão (Fonte: Autor)

\begin{tabular}{ccccc}
\hline $\begin{array}{c}\text { Teor de fibras } \\
(\%)\end{array}$ & $\begin{array}{c}\text { Quantidade de } \\
\text { amostras }\end{array}$ & $\begin{array}{c}\text { Resistência à } \\
\text { tração na flexão }- \\
7 \text { dias (MPa) }\end{array}$ & $\begin{array}{c}\text { Desvio padrão } \\
\text { (MPa) }\end{array}$ & $\begin{array}{c}\text { Coeficiente de } \\
\text { variação (\%) }\end{array}$ \\
\hline 0 & 6 & 7,18 & 0,59 & 8,27 \\
1 & 6 & 7,88 & 0,29 & 3,68 \\
2 & 6 & 7,97 & 0,24 & 3,01 \\
\hline
\end{tabular}

Os resultados para todos os corpos de prova são mostrados no Anexo A.

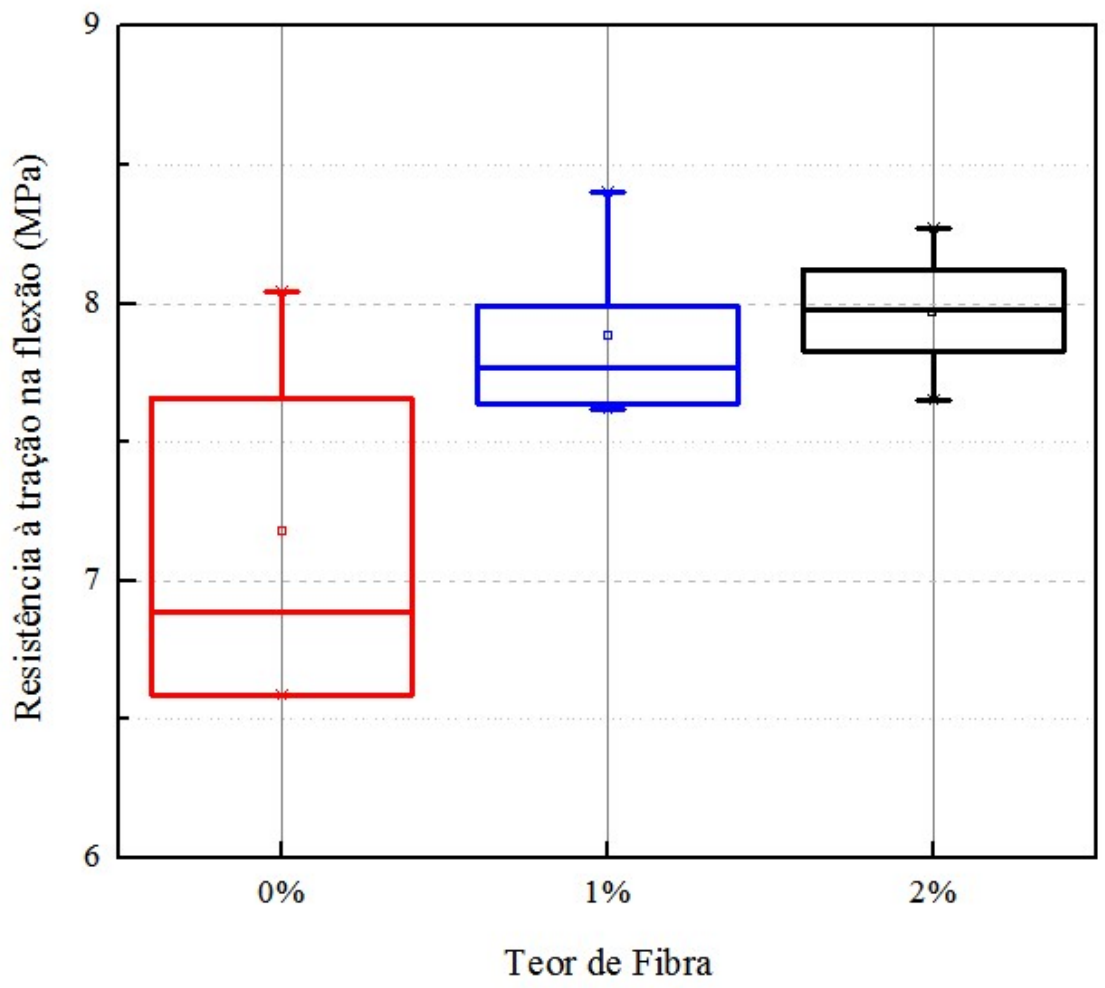

Figura 5.4 - Resultados do ensaio de tração na flexão (Fonte: Autor) 


\subsubsection{Ensaio de tenacidade}

Para o ensaio de tenacidade, os resultados são mostrados nas Figura 5.5, Figura 5.6, Figura 5.7, Figura 5.8 e na Tabela 5.6. CMOD significa, nos gráficos apresentados, Crack Mouth Opening Displacement que, por sua vez, é o mesmo que abertura de fissura. Usou-se a mesma sigla da norma base para este ensaio. Todos os gráficos foram apresentados com a escala das abscissas até $0,5 \mathrm{~mm}$, mas os valores para os teores de fibras de polipropileno 1 e $2 \%$ iam até 4 $\mathrm{mm}$, onde se interrompeu o ensaio. Durante a moldagem dos corpos de prova, duas amostras do teor de $1 \%$ de fibras foram comprometidas e foram descartadas do ensaio, logo apenas quatro amostras foram estudas para esse teor.

Tabela 5.6 - Resultados dos ensaios de tenacidade (Fonte: Autor)

\begin{tabular}{ccccc}
\hline $\begin{array}{c}\text { Teor de fibras } \\
(\%)\end{array}$ & $\begin{array}{c}\text { Quantidade de } \\
\text { amostras }\end{array}$ & $\begin{array}{c}\text { Energia - } \\
\text { tenacidade } \\
(\mathbf{N . m m})\end{array}$ & $\begin{array}{c}\text { Desvio padrão } \\
(\mathbf{m m})\end{array}$ & $\begin{array}{c}\text { Coeficiente de } \\
\text { variação (\%) }\end{array}$ \\
\hline 0 & 6 & 104,50 & 9,56 & 9,15 \\
1 & 4 & 2873,68 & 265,64 & 9,24 \\
2 & 6 & 3932,92 & 293,02 & 7,45 \\
\hline
\end{tabular}

A magnitude da tenacidade depende diretamente da geometria do corpo de prova e da configuração do carregamento. Todas as amostras ensaiadas na pesquisa apresentavam essas mesmas configurações, geométrica e de carregamento, portanto pode-se então analisar os resultados obtidos comparando-se os resultados para amostras com teores de fibras de polipropileno variando entre 0,1 e $2 \%$.

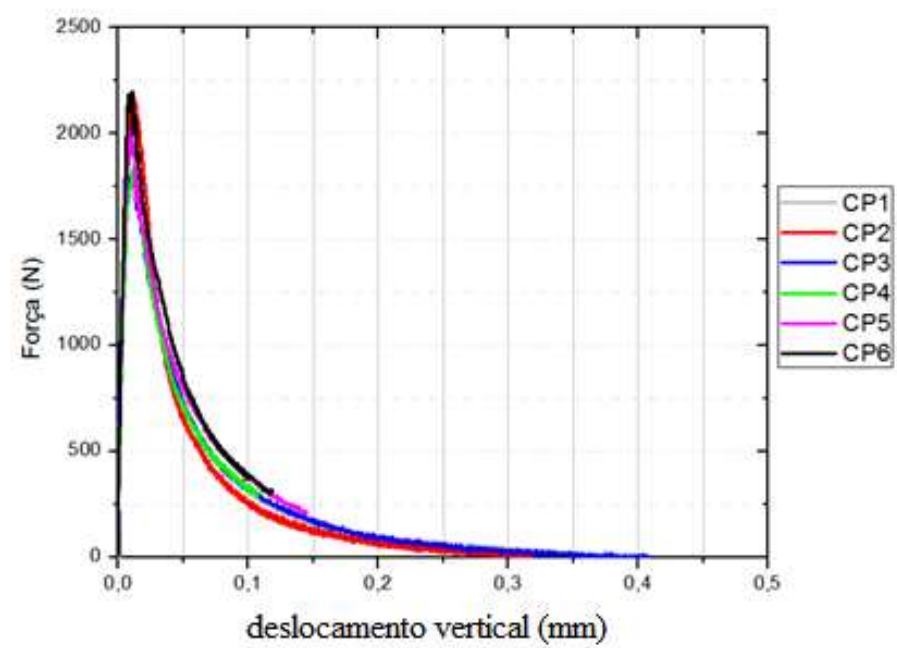

Figura 5.5- Curvas Força-Deslocamento vertical de ensaio de tenacidade para teor de fibra 0\% (Fonte: Autor) 


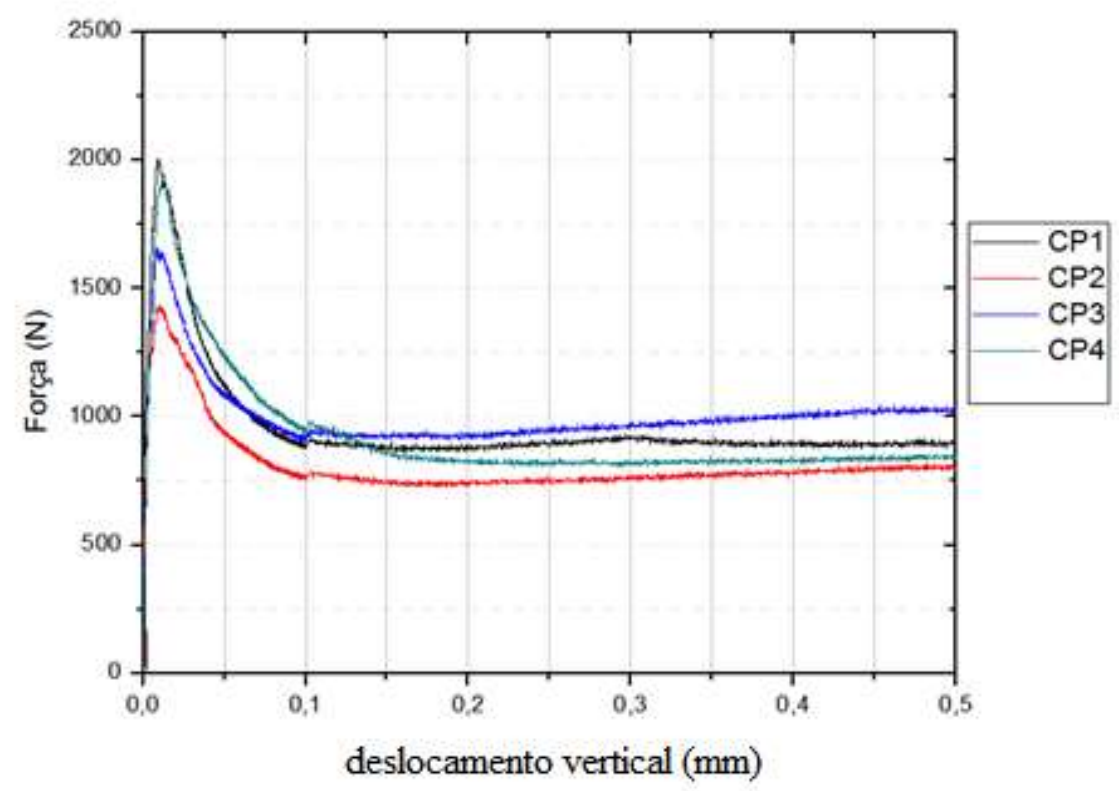

Figura 5.6 - Curvas Força-deslocamento vertical de ensaio de tenacidade para teor de fibra 1\% (Fonte: Autor)

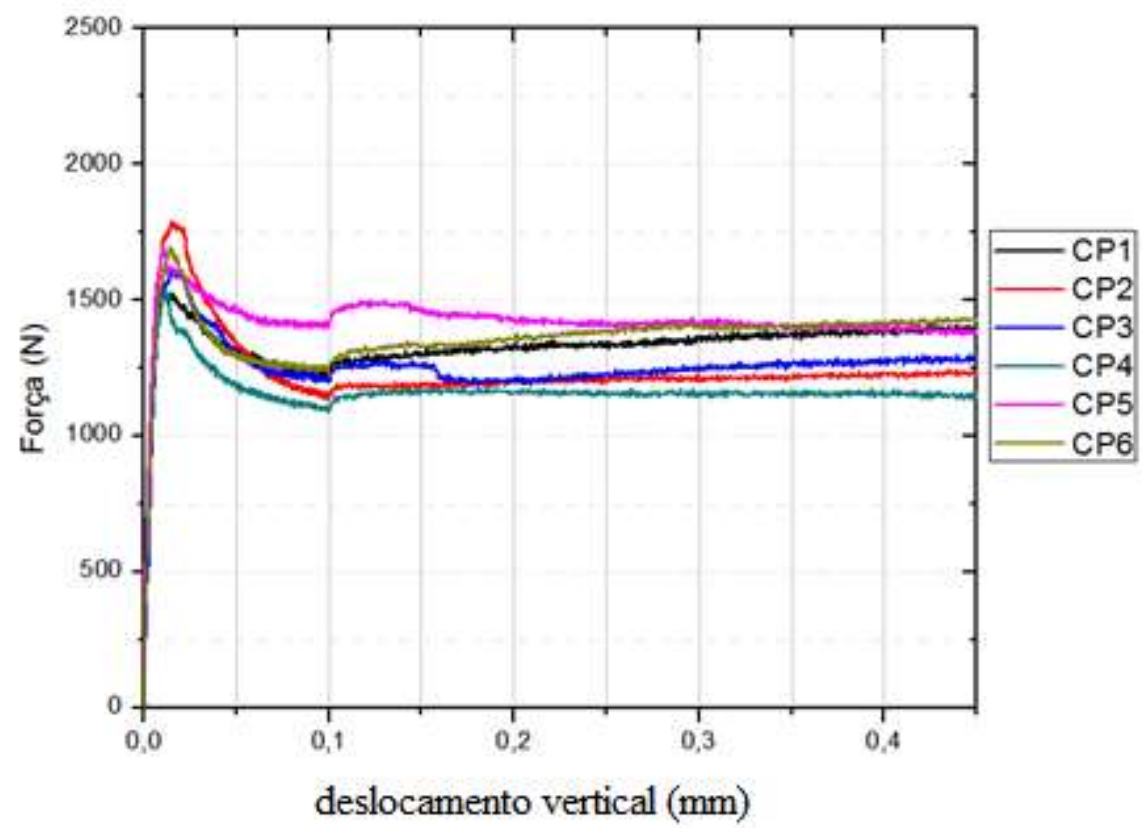

Figura 5.7 - Curvas Força-deslocamento vertical de ensaio de tenacidade para teor de fibra 2\% (Fonte: Autor)

Os resultados mostram a grande influência na tenacidade da incorporação de altos teores de fibras. Verificando-se a média das energias obtidas das amostras de 0 para 1 e de 0 para $2 \%$ de fibras, checou-se uma diferença de cerca 27 e 37 vezes respectivamente.

Na Figura 5.8 traçou-se as curvas médias para cada um dos teores para se comparar o comportamento da influência do teor de fibra para tenacidade. 


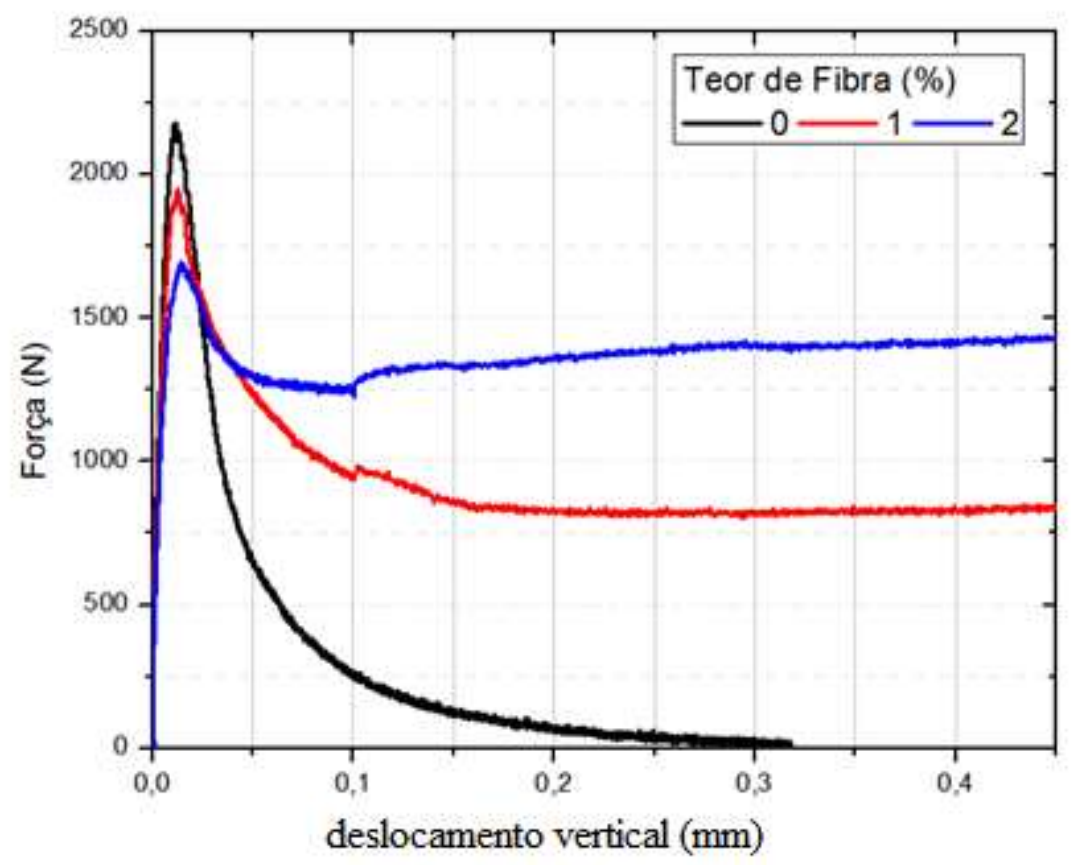

Figura 5.8 - Curvas médias de Força - deslocamento vertical para os teores de fibra 0, 1 e 2\% (Fonte: Autor)

\subsection{Ensaio nos corpos de prova do painel alveolar}

\subsubsection{Ensaio de carga concentrada}

Para o ensaio de carga concentrada, das quatro amostras ensaiadas para o teor sem fibras, apenas foi possível se aproveitar um resultado, isso devido às fissurações decorrentes da aplicação da carga concentrada em outros pontos do modelo, o que geraria falsos resultados. Para as amostras com teores de $2 \%$ de fibras de polipropileno, dos quatro modelos, foi descartado apenas um devido ao mesmo problema já citado.

Verificou-se que o comportamento do modelo contendo $2 \%$ de fibras de polipropileno em relação ao modelo de referência, apresentou, aproximadamente, dez vezes maior capacidade de carga e cinco vezes maior capacidade de deslocamento. Os resultados dos ensaios são apresentados nas Figura 5.9. 


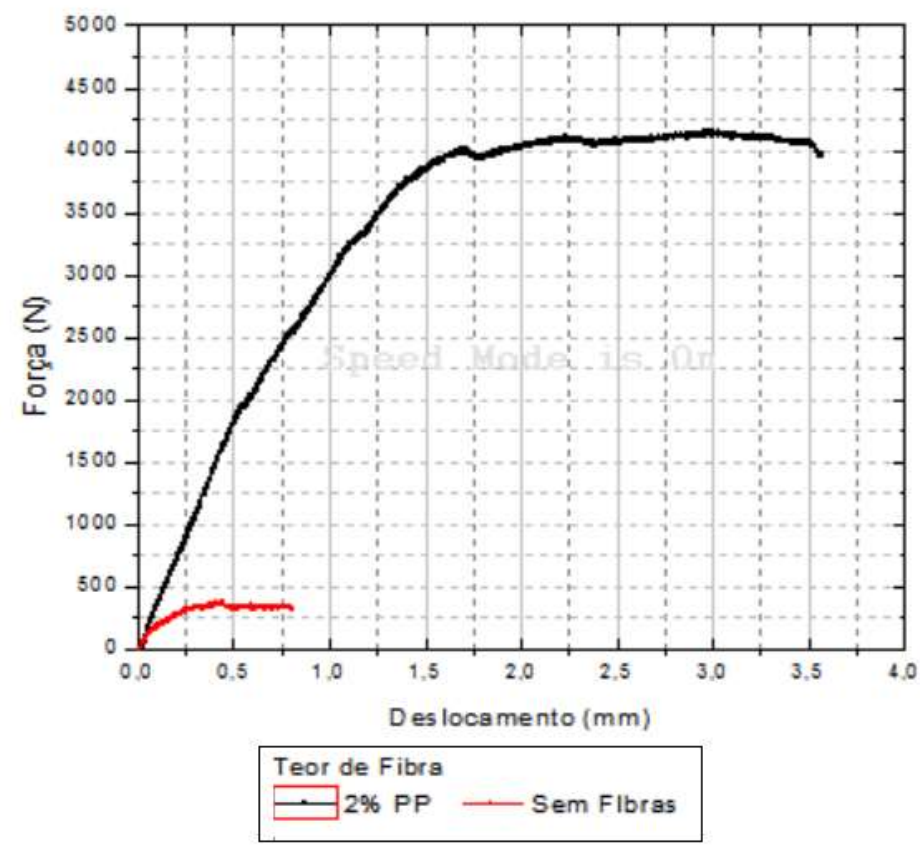

Figura 5.9 - Gráfico da curva média da Força-Deslocamento do ponto do ensaio de carga concentrada para a teor de fibra de $2 \%$ e traço de referência (espessura da parede de $12 \mathrm{~mm}$ ) (Fonte: Autor)

A espessura da parede do corpo de prova do painel alveolar também foi um parâmetro analisado neste ensaio, porém só pôde ser avaliado para as amostras contendo $2 \%$ de fibras. Quanto maior a espessura da parede do painel, maior a capacidade de carga e deslocamento observados. Ao final dos ensaios, extraíram-se os troncos de cone do material no ponto de aplicação de carga. A partir do diâmetro da base e do valor da carga máxima aplicada, calculouse a resistência à punção. A Tabela 5.7 apresenta os resultados obtidos.

Para a espessura da parede do painel de $12 \mathrm{~mm}$ observou-se um aumento de aproximadamente 7 vezes da resistência à punção para o modelo de $2 \%$ de fibras de polipropileno com relação ao traço de referência.

Tabela 5.7 - Resumo dos resultados do ensaio de carga concentrada (Fonte: Autor)

\begin{tabular}{cccccc}
\hline $\begin{array}{c}\text { Corpo de } \\
\text { prova }\end{array}$ & $\begin{array}{c}\text { Teor de } \\
\text { fibra }\end{array}$ & Espessura (cm) & Carga (N) & $\begin{array}{c}\text { Diâmetro do } \\
\text { tronco de cone } \\
(\mathbf{m m})\end{array}$ & $\begin{array}{c}\text { Resistência à } \\
\text { Punção (MPa) }\end{array}$ \\
\hline CP-0-1 & $0 \%$ & 12 & 389,54 & 50 & 0,20 \\
CP-2-1 & $2 \%$ & 12 & 4184,9 & 60 & 1,48 \\
CP-2-2 & $2 \%$ & 13,5 & 4238,28 & 60 & 1,49 \\
CP-2-3 & $2 \%$ & 15 & 4630,12 & 58 & 1,75 \\
\hline
\end{tabular}




\subsubsection{Ensaio de flexão}

Os resultados para o ensaio de flexão são mostrados na Figura 5.10 e na Figura 5.11. A Figura 5.10 mostra os resultados das amostras sem fibras, já a Figura 5.11 das amostras contendo $2 \%$ de fibras de polipropileno, e ambas mostram graficamente um comparativo dos dois resultados.

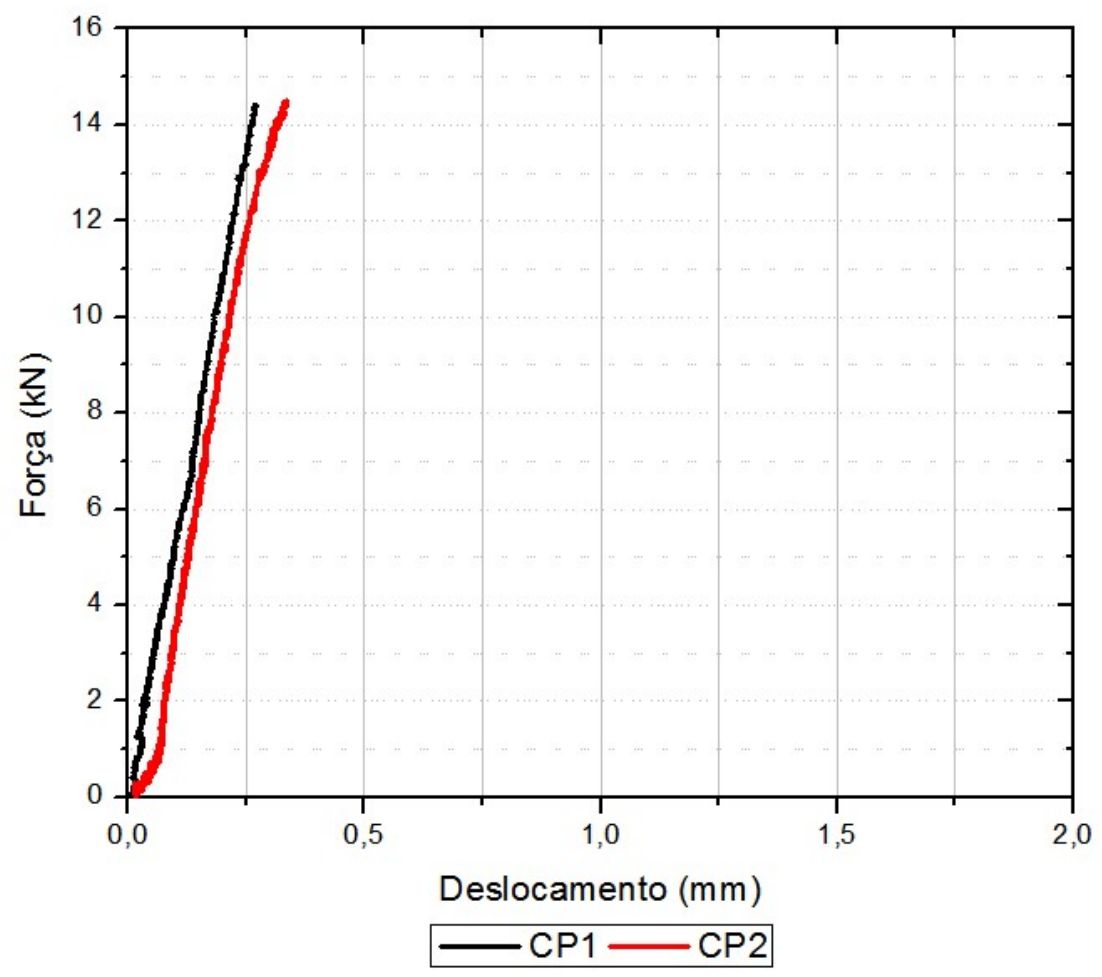

Figura 5.10 - Gráfico Força-Deslocamento do ensaio de flexão das amostras sem fibras (Fonte: Autor) 


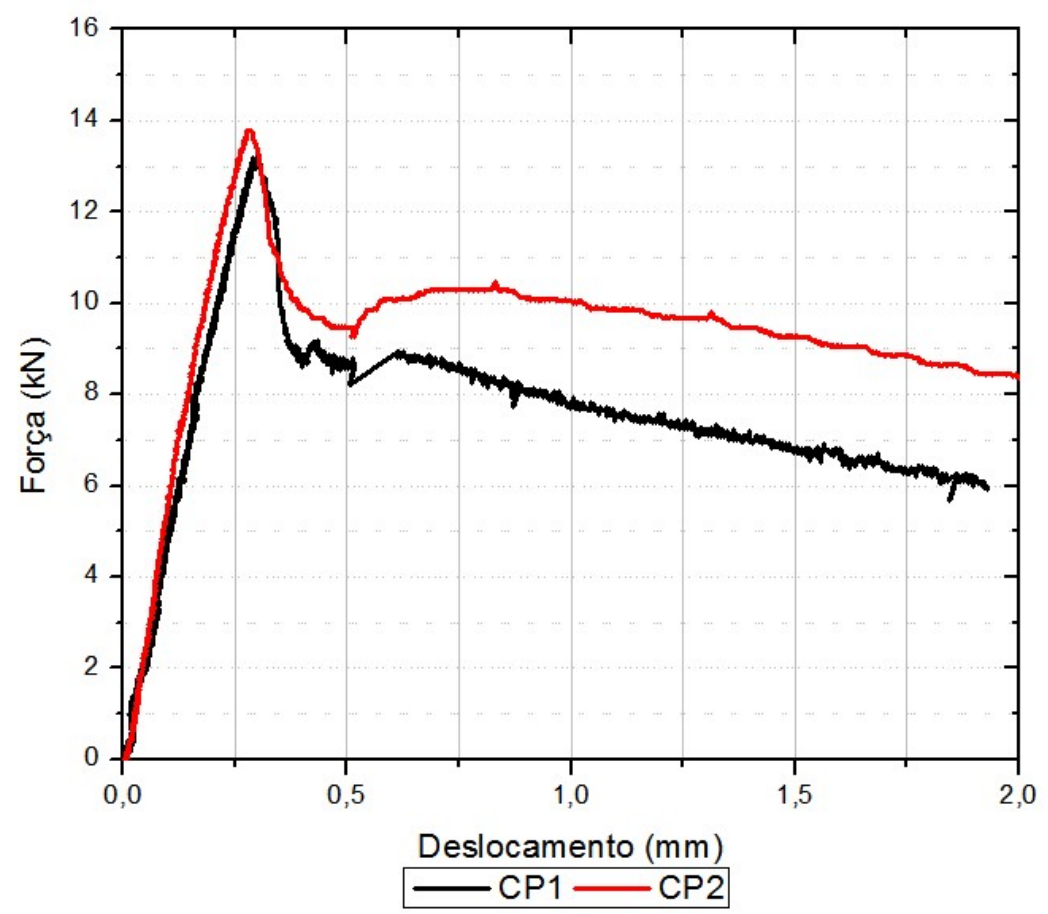

Figura 5.11 - Gráfico Força-Deslocamento do ensaio de flexão das amostras com 2\% de fibras de polipropileno (Fonte: Autor)

Realizou-se uma previsão de carga de ruptura, segundo a teoria da mecânica dos sólidos, de acordo com os resultados obtidos nos ensaios de caracterização de resistência à tração. A Tabela 5.8 e a

Tabela 5.9 apresentam as cargas máximas obtidas para o cálculo da tensão e os momentos de inércia que foram calculados de acordo com a seção transversal do corpo de prova do painel moldado.

A Figura 5.12 apresenta a configuração de carregamento do ensaio e a configuração diagrama de momento fletor. 

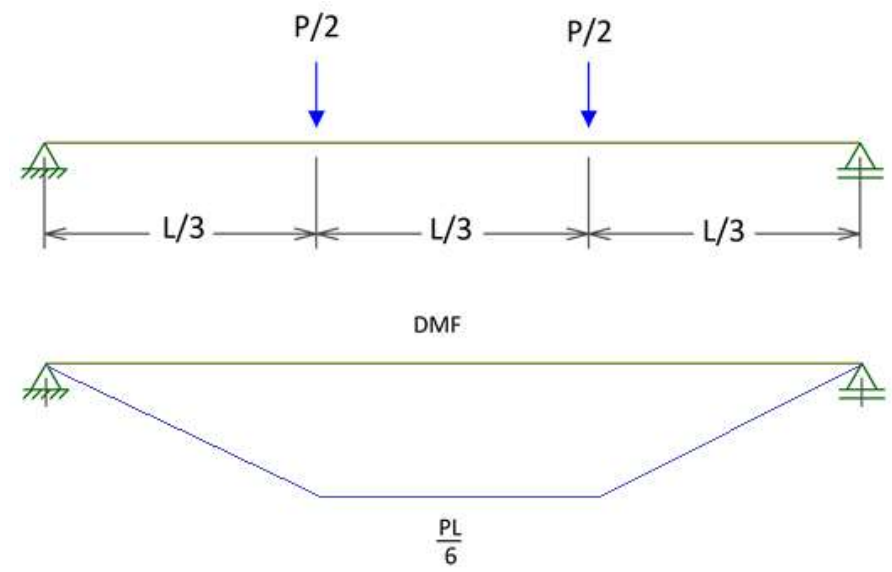

Figura 5.12 - Configuração do carregamento do ensaio e diagrama de momento fletor subsequente (Fonte: Autor)

A ABNT NBR 6118:2014 em seu item 17.3.1, recomenda correlacionar a resistência à tração na flexão com a resistência à tração direta por meio do fator $\alpha$, que leva em consideração a geometria da seção transversal. Admitindo que a seção transversal do corpo de prova do painel alveolar corresponde a uma seção I, o valor aproximado de $\alpha$ equivale à 1,2. Logo, tem-se que:

$$
\sigma=\frac{M \cdot y}{I} \rightarrow \alpha \cdot f_{c t}=\frac{M \cdot y}{I}
$$

A ABNT NBR 6118:2014, em seu item 8.2.5, afirma que o valor da resistência à tração direta pode ser considerada igual a $0,7 \mathrm{fct}_{\mathrm{ct}}$. Logo tem-se que:

$$
\alpha \cdot f_{c t}=\frac{M \cdot y}{I} \rightarrow 1,2 \cdot 0,7 \cdot f_{c t, f,}=\frac{M \cdot y}{I} \rightarrow 0,84 \cdot f_{c t, f,}=\frac{M \cdot y}{I}
$$

A partir da Figura 5.12 - Configuração do carregamento do ensaio e diagrama de momento fletor subsequente (Fonte: Autor) tem-se:

$$
M=\frac{P L}{6}
$$

Logo obtém-se uma expressão para estimar a carga máxima de ensaio por:

$$
0,84 \cdot f_{c t, f,}=\left(\frac{P L}{6}\right) \frac{y}{I} \rightarrow P=\frac{6 \cdot 0,84 \cdot f_{c t, f} \cdot I}{L \cdot y} \rightarrow P=\frac{5,04 \cdot f_{c t, f} \cdot I}{L \cdot y}
$$

Conforme apresentado na Figura 4.18 - Localização dos transdutores de deslocamento em corte (a) e em planta (b) do corpo de prova do painel para o ensaio de flexão, o vão (L) do ensaio é igual a $900 \mathrm{~mm}$, e a seção transversal do corpo de prova apresenta uma altura de 140 
$m m$, logo o valor de y para o maior valor de tensão normal equivale a $70 \mathrm{~mm}$ (distância a partir da linha neutra da peça). Substituindo esses valores na equação, obtém-se:

$$
P=\frac{5,04 \cdot f_{c t, f} \cdot I}{63000}
$$

Sendo:

$\mathrm{P}=$ Carga de ruptura estimada $(k N)$;

$\mathrm{f}_{\mathrm{ct}, \mathrm{f}}=$ Resistência a tração na flexão média dos ensaios de caracterização $\left(\mathrm{kN} / \mathrm{mm}^{2}\right)$;

$\mathrm{I}=$ Momento de inércia $\left(\mathrm{mm}^{4}\right)$

Tabela 5.8 - Resultados do ensaio de flexão para amostras sem fibras (Fonte: Autor)

\begin{tabular}{cccc}
\hline Corpo de prova & $\begin{array}{c}\text { Momento de Inercia } \\
\left(\mathbf{m m}^{4}\right)\end{array}$ & Carga Máxima (kN) & $\begin{array}{c}\text { Tensão máxima } \\
(\text { MPa) }\end{array}$ \\
\hline Estimado & $3,06 \times 10^{7}$ & 17,57 & 5,03 \\
1 & $3,27 \times 10^{7}$ & 14,41 & 4,29 \\
2 & $3,19 \times 10^{7}$ & 14,24 & 4,24 \\
\hline Média & $3,23 \times 10^{7}$ & 14,33 & 4,27 \\
\hline
\end{tabular}

Tabela 5.9 - Resultados do ensaio de flexão para amostras com $2 \%$ de fibras de polipropileno (Fonte: Autor)

\begin{tabular}{cccc}
\hline Corpo de prova & $\begin{array}{c}\text { Momento de Inercia } \\
\left(\mathbf{m m}^{\mathbf{4}}\right)\end{array}$ & Carga Máxima $(\mathbf{k N )})$ & $\begin{array}{c}\text { Tensão normal } \\
\text { máxima (MPa) }\end{array}$ \\
\hline Estimado & $3,06 \times 10^{7}$ & 19,51 & 5,57 \\
1 & $3,37 \times 10^{7}$ & 13,19 & 3,93 \\
2 & $3,29 \times 10^{7}$ & 13,79 & 4,11 \\
\hline Média & $3,33 \times 10^{7}$ & 13,49 & 4,02 \\
\hline
\end{tabular}

Os resultados apresentados diferiram em relação ao valor estimado a partir da teoria da mecânica dos sólidos, cerca de 22\% para amostras sem fibras e 45\% para amostras contendo $2 \%$ fibras de polipropileno. 
Comparando-se os valores médios obtidos das cargas e tensões normais máximas, as amostras sem fibras apresentaram resistência à flexão aproximadamente $6 \%$ maior com relação às amostras com $2 \%$ de fibras. Se o comportamento apresentado pelo material fosse o esperado, conforme os valores de carga máxima e tensões estimados, os corpos de prova contendo $2 \%$ de fibras apresentariam carga máxima cerca $11 \%$ maior e tensão normal.

Isso se deve à dificuldade no ato da moldagem do corpo de prova, pois com a trabalhabilidade muito baixa em conjunto com a geometria do painel, não foi possível realizar o adensamento corretamente. Portanto, um mau adensamento acarreta maior número de vazios no compósito, comprometendo algumas de suas propriedades mecânicas. 


\section{CONCLUSÃO E CONSIDERAÇÕES FINAIS}

As conclusões são apresentadas separadamente para os ensaios de caracterização e os ensaios nos painéis.

Das análises dos ensaios de caracterização nas argamassas, conclui-se que:

- $\quad$ O índice de consistência da argamassa no estado fresco, parâmetro usado para se avaliar a trabalhabilidade, é significativamente alterado com a adição dos altos teores de fibras, apresentando nessa pesquisa uma redução de respectivamente $38 \%$ e $48 \%$ para os teores 1 e $2 \%$ de fibras de polipropileno.

- $\quad$ A adição de alto teor de fibras de polipropileno indica pouca interferência sobre os valores de resistência à compressão e módulo de elasticidade, estes valores são respectivamente de $6 \%$ e $12,31 \%$ maiores para os teores de $2 \%$ de fibras com relação ao traço de referência.

- $\quad$ A resistência à tração na flexão não apresentou o mesmo comportamento da resistência à tração por compressão diametral. Quando comparadas as médias obtidas em relação à argamassa de referência, o ensaio de tração na flexão para o teor de $2 \%$ de fibras apresentou valores $11,79 \%$ superiores, o que não indicou, por esta análise, diferenças significativas. Enquanto que para o ensaio de tração por compressão diametral, este valor foi cerca de $26 \%$ superior para o teor de $2 \%$ de fibras com relação à argamassa de referência. Isto pode ser problema de sensibilidade das células de carga de equipamentos diferentes.

- De acordo com os parâmetros da norma adaptada para o ensaio de tenacidade, esta foi a propriedade do compósito mais afetada pela adição dos altos teores de fibras. Os ensaios realizados mostraram valores de absorção de energia mecânica 27 e 37 vezes maiores respectivamente para os teores de 1 e $2 \%$ de fibras de polipropileno, quando comparados às argamassas sem fibras.

Das análises dos ensaios nos painéis alveolares, conclui-se que:

- Em relação ao ensaio de carga concentrada, o comportamento do modelo contendo 2\% de fibras de polipropileno em relação ao modelo de referência, apresentou aproximadamente dez vezes maior capacidade de carga, cinco vezes maior capacidade de deslocamento e sete vezes maior resistência à punção. Porém, deve-se levar em conta 
o baixo número de modelos ensaiados para o modelo de referência, devido aos problemas de fissurações citados no capítulo de análise de resultados.

- $\quad$ As tensões resistentes à flexão apresentaram valores cerca de $6 \%$ menores para as amostras contendo $2 \%$ de fibras. Isso se deve à dificuldade no ato da moldagem do corpo de prova, pois a trabalhabilidade muito baixa em conjunto com a geometria do painel, torna difícil realizar o adensamento corretamente. Quanto maior o número de vazios, maior a perda de algumas propriedades mecânicas de um compósito. Em boas condições de moldagem e adensamento, a tendência é que essas tensões resistentes à flexão sejam maiores.

Sugestão para trabalhos futuros:

- Estudar o comportamento à flexão, carga concentrada e compressão em modelos de painéis alveolares contendo teores de fibras de polipropileno abaixo de $2 \%$, verificando se há melhora nas condições de moldagem dos painéis.

- Estudar a influência de adição de altos teores de outras fibras de peso específico baixo com relação às fibras de aço, como as fibras de vidro.

- $\quad$ Estudar, por meio de simulações numéricas, o comportamento do modelo do painel, alterando-se variáveis de geometria, tipo de fibra, teor de fibras e orientação das fibras. 


\section{REFERÊNCIAS BIBLIOGRÁFICAS}

AMERICAN SOCIETY FOR TESTING AND MATERIALS - ASTM E1876-01, Standard Test Method for Dynamic Young' s Modulus, Shear Modulus, and Poisson 's Ratio by Impulse Excitation of Vibration. [S.1: s.n.], 2001.

. ASTM C1609, Standard Test Method for Flexural Performance of Fiber-Reinforced Concrete (Using Beam With Third-Point Loading) [S.l: s.n.], 2012.

ASTM C215-02, Standard Test Method for Fundamental Transverse, Longitudinal, and Torsional Resonant Frequencies of Concrete Specimens. [S.1: s.n.], 2003.

ARAÚJO, C. T. F. Estudo do Comportamento de Juntas de Argamassa Reforçadas com Fibras de Polipropileno. 94p. Dissertação (Mestrado) - Universidade Federal de Alagoas, Maceió, 2005.

ASSOCIAÇÃO BRASILEIRA DE NORMAS TÉCNICAS. NBR 7251: Agregado em estado Solto - Determinação da massa unitária. Rio de Janeiro, 1982.

NBR 9776: Agregados - Determinação da massa específica de agregados miúdos por meio do frasco Chapman. Rio de Janeiro, 1987.

NBR 13276: Argamassa para assentamento e revestimento de paredes e tetos - Preparo da mistura e determinação do índice de consistência. Rio de Janeiro, 2005.

NBR 7222: Argamassas e concretos - Determinação da resistência à tração na compressão diametral de corpos-de-prova cilíndricos; método de ensaio. Rio de Janeiro, 1994.

NBR 5732: Cimento Portland Comum. Rio de Janeiro, 1991.

Janeiro, 1996.

NBR 7215: Cimento Portland - Determinação da resistência à compressão. Rio de

NBR 12142: Concreto - Determinação da resistência à tração na flexão em corpos-deprova prismáticos. Rio de Janeiro, 1991.

Janeiro, 2007.

NBR 5739: Concreto - Ensaio de compressão de corpos-de-prova cilíndricos. Rio de

. NBR 11675: Divisórias leves internas moduladas - Verificação da resistência aos impactos. Rio de Janeiro, 2016. Janeiro, 2006.

NBR 9062: Projeto e Execução de Estruturas de Concreto Pré-moldado. Rio de

NBR NM 248: Agregados - Determinação da composição granulométrica. Rio de Janeiro, 2003.

BACHMAnN, H.; STEInlE, A. Precast Concrete Structures, 1ed. Berlin: Ernst \& Sohn, 2011. 
BENTUR, A.; MINDESS, S. Fibre Reinforced Cementitious Composites. 2ed. London: Elsevier, 1990.

CASTILHO. V. C. Análise estrutural de painéis de concreto pré-moldado considerando a interação com a estrutura principal. 154p. Dissertação (Mestrado) - Escola de Engenharia de São Carlos, Universidade de São Paulo, São Carlos, 1998.

CHOI, T.; YUAN, R.L.. Experimental relationship between splitting tensile strengh and compressive strength of GFRC and PFRC. Cement and Concrete Research, v. 35, p. 1587 $1591,2005$.

DITZ, J. D. Desempenho de almofadas de argamassa modificada na transferência de tensões de compressão em ligações de concreto pré-moldado. 142p. Dissertação (Mestrado) - Escola de Engenharia de São Carlos, Universidade de São Paulo, São Carlos, 2015.

EL DEBS, M.K. Concreto pré-moldado: fundamentos e aplicações. EESC - USP, São Carlos, 2000.

EL DEBS, M.K. Sistema Construtivo com componentes pré-fabricados a base de paineis alveolares de material cimentício. Registro de estudo feito junto ao CONFEA, São Carlos, 2016.

ELLIOTT, K. S. Precast Concrete Structures, 1ed. Oxford: Butterworth-Heinemann, 2002.

FÉDÉRATION INTERNATIONALE DU BETON - FIB; Prefabrication for affordable housing. State-of-art report. fib bulletin $60 ; 2010$.

GENCEL, O.; OZEL, C.; BROSTOW, W.; MARTINEZ-BARRERA, G. Mechanical properties of self-compacting concrete reinforced with polypropylene fibres. Materials Research Innovations, v. 15, p. 216 - 225, 2011.

HAACH, V. G.; CARRAZEDO, R.; OLIVEIRA, L. M. F.; CORRÊA, M. R. S. Application of acoustic tests to mechanical characterization of masonry mortars. NDT \& E International, v. 59, p. 18-24, doi:10.1016/j.ndteint.2013.04.013, 2013.

HASSANPOUR, M.; SHAFIGH, P.; MAHMUD, H.B. Lightweight aggregate concrete fiber reinforcement - a review. Construction and Building Materials, v. 37, p. 452 - 461, 2012.

HSIE, M.; TU, C.; SONG, P.S. Mechanical properties of polypropylene hybrid fiber-reinforced concrete. Materials Science and Engineering A, v. 494, p. 153 - 157, 2008.

JIANG, W.; ROY, D. M. Mechanical behaviour of advanced cementitious materials. 9th International Congress on the Chemistry of Cement. p. 268-74. 1992.

KAKOOEI, S.; AKIL, H.M.; JAMSHIDI, M.; ROUHI, J. The effects of polypropylene fibers on the properties of reinforced concrete structures. Construction and Building Materials, v. 27, p. $73-77,2012$.

KIM, Y.; HU, J.; LEE, S.; YOU, B. Mechanical properties of fiber reinforced lightweight concrete containing surfactant. Advances in Civil Engineering, v. 2010, 8 p, 2010

MEHTA, P. K.; MONTEIRO, P.J.M.; Concreto. Microestrutura, Propriedades e Materiais. 1ed. São Paulo: IBRACON, 2008. 
MOGRE, R.P.; PARBAT, D.K. Behavior of polypropylene fibre reinforced concrete with artificial sand. International Refereed Journal of Engineering and Science, v. 1, issue 2, p. $37-40,2012$.

SHAH, S. P. Do fibers increase the tensile strength of cement-based matrixes?. ACI Materials Journals. 88(6). p. 595-602. 1991.

SONG, P.S.; HWANG, S.; SHEU, B.C. Strength properties of nylon- and polypropylene-fiberreinforced concretes. Cement and Concrete Research, v. 35, p. 1546 - 1550, 2005.

ZEIML, M.; LEITHNER, D.; LACKNER, R.; MANG, H. How do polypropylene fibers improve the spalling behavior of in situ concrete?. Cement and Concrete Research, v. 36, p. 929-942, 2006. 


\section{ANEXO A - RESULTADO DOS ENSAIOS EXPERIMENTAIS}

Resultados dos estudos preliminares de dosagem:

a) Traço em massa:

Tabela A.1 - Traço em massa das argamassas do estudo preliminar (Fonte: Autor)

\begin{tabular}{cccccc}
\hline Traço & Cimento & Areia & Água & $\begin{array}{c}\text { Super } \\
\text { plastificante }\end{array}$ & $\begin{array}{c}\text { Fibras PP } \\
\text { (\% vol) }\end{array}$ \\
\hline 1 & 1 & 2 & 0,35 & 0,01 & 0 \\
2 & 1 & 2 & 0,40 & 0,01 & 0 \\
3 & 1 & 2 & 0,45 & 0,01 & 0 \\
\hline 4 & 1 & 2 & 0,35 & 0,02 & 1 \\
5 & 1 & 2 & 0,40 & 0,02 & 1 \\
6 & 1 & 2 & 0,45 & 0,02 & 2 \\
\hline 7 & 1 & 2 & 0,35 & 0,02 & 2 \\
\hline
\end{tabular}

b) Resistência à compressão e módulo de elasticidade longitudinal:

Tabela A.2 - Resultados dos ensaios de resistência à compressão - relação a/c 0,35 (Fonte: Autor)

\begin{tabular}{lccc} 
& \multicolumn{3}{c}{ Resistência à compressão (Mpa) } \\
\cline { 2 - 4 } & \multicolumn{3}{c}{ Teor de fibras (\%) } \\
\cline { 2 - 4 } & $\mathbf{0}$ & $\mathbf{1}$ & $\mathbf{2}$ \\
\hline & 70,77 & 56,86 & 59,78 \\
& 76,61 & 59,37 & 62,63 \\
& 75,12 & 55,15 & 64,58 \\
& 79,9 & 61,97 & 52,05 \\
& 79,19 & - & 55,35 \\
\hline Média & 76,33 & 57,87 & 58,88 \\
Desvio & 77,99 & 2,78 & 5,16 \\
padrão & 2,27 & & \\
\hline
\end{tabular}


Tabela A.3 - Resultados dos ensaios de resistência à compressão - relação a/c 0,4 (Fonte: Autor) Resistência à compressão $(\mathrm{Mpa}) \quad$ Módulo de elasticidade longitudinal (GPa)

\begin{tabular}{ccccccc} 
& \multicolumn{3}{c}{ Teor de fibras (\%) } & \multicolumn{3}{c}{ Teor de fibras (\%) } \\
\cline { 2 - 7 } & $\mathbf{0}$ & $\mathbf{1}$ & $\mathbf{2}$ & $\mathbf{0}$ & $\mathbf{1}$ & $\mathbf{2}$ \\
\cline { 2 - 7 } & 70,69 & 47,89 & 49,88 & 40,6 & 35,3 & 35,3 \\
& 73,41 & 48,59 & 51,96 & 40,61 & 36,3 & 36,83 \\
& 73,91 & 38,87 & 50,1 & 40,22 & 36,83 & 40,8 \\
& 70,22 & 46,08 & 51,24 & 40,92 & 36,62 & 40,92 \\
& 72,45 & 49,29 & 50,12 & 40,56 & 36,58 & 39,12 \\
& 71,17 & 46,28 & - & 40,98 & - & - \\
\hline Média & 71,98 & 46,17 & 50,66 & 40,65 & 36,33 & 38,59 \\
Desvio & 1,51 & 3,79 & 0,90 & 0,28 & 0,60 & 2,48 \\
padrão & & & & & & \\
\hline
\end{tabular}

Tabela A.4 - Resultados dos ensaios de resistência à compressão - relação a/c 0,45 (Fonte: Autor)

\begin{tabular}{ccccccc}
\hline & \multicolumn{3}{c}{ Resistência à compressão (Mpa) } & \multicolumn{3}{c}{ Módulo de elasticidade longitudinal } \\
Corpo de prova & \multicolumn{3}{c}{ Teor de fibras (\%) } & \multicolumn{3}{c}{ Teor de fibras (\%) } \\
\cline { 2 - 7 } & $\mathbf{0}$ & $\mathbf{1}$ & $\mathbf{2}$ & $\mathbf{0}$ & $\mathbf{1}$ & $\mathbf{2}$ \\
\cline { 2 - 7 } & 39,91 & 37,12 & 38,89 & 26,14 & 29,59 & 28,45 \\
$\mathbf{1}$ & 39,78 & 41,89 & 36,13 & 25,78 & 28,26 & 30,89 \\
$\mathbf{3}$ & 38,76 & 37,45 & 38,71 & 26,26 & 30,48 & 29,19 \\
$\mathbf{4}$ & 37,90 & 37,34 & 36,57 & 26,93 & 29,39 & 33,51 \\
$\mathbf{5}$ & 40,18 & 39,78 & 37,02 & 24,30 & 30,47 & 28,98 \\
$\mathbf{6}$ & 38,43 & 36,12 & 36,91 & 27,01 & 27,73 & 34,28 \\
\hline Média & 39,16 & 38,28 & 37,37 & 26,07 & 29,32 & 30,88 \\
Desvio padrão & 0,92 & 2,14 & 1,15 & 0,99 & 1,13 & 2,48 \\
\hline
\end{tabular}


Resultados dos ensaios de caracterização

a) Compressão axial:

Tabela A.5 - Resultados do ensaio de compressão axial (Fonte: Autor)

\begin{tabular}{cccc}
\hline \multicolumn{3}{c}{ Resistência à Compressão a 7 dias (MPa) } \\
\cline { 2 - 4 } & $\mathbf{0}$ & Teor de fibras (\%) \\
\hline 39,94 & $\mathbf{1}$ & $\mathbf{2}$ \\
39,25 & 41,12 & 38,11 \\
37,21 & 38,26 & 38,13 \\
37,28 & 39,88 & 33,89 \\
41,61 & 37,55 & 38,78 \\
& - & 40,39 & 35,15 \\
& - & 43,6 & 38,71 \\
& 42,33 & 36,81 & 38,77 \\
& 39,85 & 34,54 & 36,01 \\
& 39,50 & 39,21 & 36,56 \\
Média & 39,62 & 44,73 & 37,59 \\
\hline 1,81 & 39,61 & 37,17 \\
\hline
\end{tabular}

b) Tração por compressão diametral:

Tabela A.6 - Resultados do ensaio de tração por compressão diametral (Fonte: Autor)

\begin{tabular}{ccc}
\hline \multicolumn{3}{c}{ Resistência à tração por compressão diametral a $\mathbf{7}$ dias (MPa) } \\
\hline \multicolumn{3}{c}{ Teor de fibras (\%) } \\
\hline $\mathbf{0}$ & $\mathbf{1}$ & $\mathbf{2}$ \\
\hline 2,86 & 2,58 & 3,38 \\
2,57 & 3,39 & 3,45 \\
2,83 & 3,47 & 3,64 \\
2,79 & 3,09 & 3,72 \\
2,40 & 2,62 & - \\
2,40 & 2,71 & -- \\
2,27 & 2,97 & 3,65 \\
2,92 & 2,84 & 3,40 \\
1,82 & 3,28 & 3,77 \\
2,30 & 3,13 & 3,40 \\
2,52 & 3,01 & 3,55 \\
0,35 & 0,32 & 0,16 \\
\hline
\end{tabular}


c) Módulo de elasticidade:

Tabela A.7 - Resultados do ensaio de módulo de elasticidade (Fonte: Autor)

\begin{tabular}{|c|c|c|c|}
\hline & \multicolumn{3}{|c|}{ Módulo de elasticidade longitudinal à 7 dias (GPa) } \\
\hline & \multicolumn{3}{|c|}{ Teor de fibras $(\%)$} \\
\hline & $\mathbf{0}$ & 1 & 2 \\
\hline & 25,68 & 28,27 & 33,11 \\
\hline & 27,19 & 28,60 & 28,35 \\
\hline & 24,02 & 29,30 & 30,71 \\
\hline & 27,89 & 27,89 & 31,37 \\
\hline & 25,72 & 30,02 & 32,90 \\
\hline & 25,55 & 28,24 & 29,72 \\
\hline & 26,63 & 29,47 & 35,44 \\
\hline & 26,51 & 30,63 & 33,76 \\
\hline & 25,06 & 29,15 & 31,28 \\
\hline & 28,45 & 26,38 & 28,05 \\
\hline & 27,49 & 30,66 & 29,61 \\
\hline & 28,59 & 27,72 & 32,74 \\
\hline & 29,78 & 27,89 & 34,03 \\
\hline & 30,12 & -- & 29,24 \\
\hline & 24,97 & 28,08 & 32,63 \\
\hline & 25,84 & 27,29 & 32,00 \\
\hline & 27,62 & 29,40 & 27,40 \\
\hline & 29,41 & 27,29 & 28,73 \\
\hline & 31,44 & 29,32 & 28,74 \\
\hline & 27,33 & 28,46 & 32,03 \\
\hline Média & 27,26 & 28,63 & 31,09 \\
\hline Desvio padrão & 1,94 & 1,15 & 2,27 \\
\hline
\end{tabular}

d) Consistência:

Tabela A.8 - Resultados do ensaio de consistência (Fonte: Autor)

\begin{tabular}{ccc}
\hline \multicolumn{3}{c}{ Índice de consistência (mm) } \\
\hline $\mathbf{0}$ & Teor de fibras $\mathbf{( \% )}$ & \\
\hline 34,66 & $\mathbf{1}$ & $\mathbf{2}$ \\
33,19 & 21,66 & 18,33 \\
34,58 & 20,54 & 16,68 \\
34,14 & 21,15 & 17,85 \\
\hline
\end{tabular}


e) Tração na flexão:

Tabela A.9 - Resultados do ensaio de tração na flexão (Fonte: Autor)

\begin{tabular}{cccc}
\hline \multicolumn{3}{c}{ Resistência à tração na flexão a 7 dias (MPa) } \\
\cline { 2 - 4 } & $\mathbf{0}$ & Teor de fibras (\%) \\
\hline 7,66 & $\mathbf{1}$ & $\mathbf{2}$ \\
\hline 7,29 & 8,40 & 8,12 \\
& 6,59 & 7,62 & 7,98 \\
& 6,89 & 7,88 & 8,27 \\
& 8,04 & 7,64 & 7,65 \\
& 6,59 & 7,99 & 7,83 \\
Média & 7,18 & 7,77 & - \\
\hline Desvio padrão & 0,59 & 7,88 & 7,97 \\
\hline
\end{tabular}

